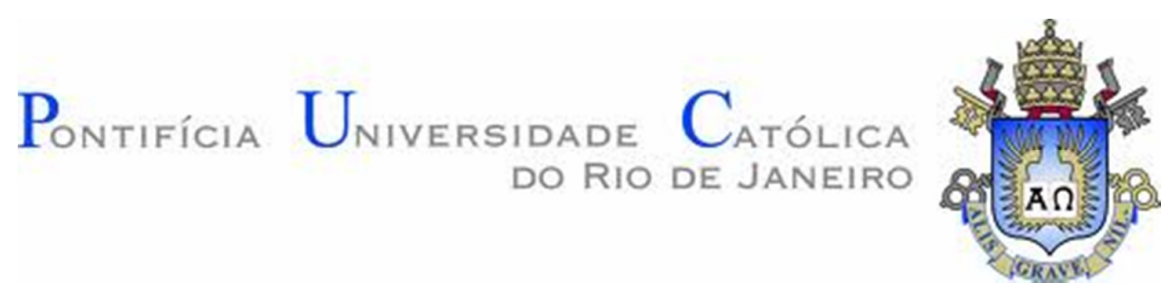

Rafael Ramos Gonçalves

\title{
A clínica da angústia
}

Dissertação de Mestrado

Dissertação apresentada como requisito parcial para obtenção do título de Mestre pelo Programa de PósGraduação em Psicologia (Psicologia Clínica) da PUC-Rio.

Orientador: Profa. Ana Maria de Toledo Piza Rudge 


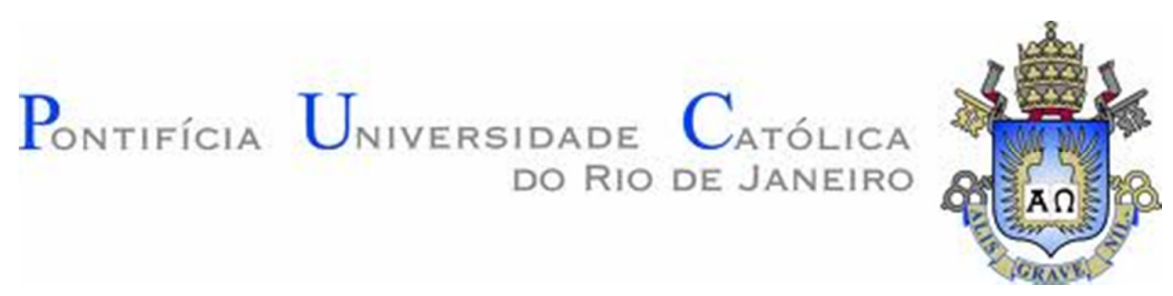

Rafael Ramos Gonçalves

A clínica da angústia

Dissertação apresentada como requisito parcial para obtenção do grau de Mestre pelo Programa de PósGraduação em Psicologia (Psicologia Clínica) do Departamento de Psicologia do Centro de Teologia e Ciências Humanas da PUC-Rio. Aprovada pela Comissão Examinadora abaixo assinada

Profa. Ana Maria de Toledo Piza Rudge Orientadora Departamento de Psicologia - PUC-Rio

Prof. Marcus André Vieira Departamento de Psicologia - PUC-Rio

Prof. Marco Antonio Coutinho Jorge UERJ

Profa. Denise Berruezo Portinari Coordenadora Setorial de Pós-Graduação e Pesquisa do Centro de Teologia e Ciências Humanas - PUC-Rio

Rio de Janeiro, 18 de março de 2014 
Todos os direitos reservados. É proibida a reprodução total ou parcial do trabalho sem autorização da universidade, do autor e do orientador.

\section{Rafael Ramos Gonçalves}

Graduação em Psicologia UERJ. Possui experiência em clínica ambulatorial (rede pública de saúde) e na assistência social. Fez especialização em Clínica Psicanalítica no IPUB/UFRJ. Tem interesse no diálogo da teoria psicanalítica com outros saberes, tais como a filosofia, literatura e arte.

Ficha Catalográfica

Gonçalves, Rafael Ramos

A clínica da angústia / Rafael Ramos Gonçalves; orientadora: Ana Maria de Toledo Piza Rudge. - 2014.

112 f. ; $30 \mathrm{~cm}$

Dissertação (mestrado)-Pontifícia Universidade Católica do Rio de Janeiro, Departamento de Psicologia, 2014.

Inclui bibliografia

1. Psicologia - Teses. 2. Sexualidade. 3. Angústia. 4. Castração. 5. Desejo. 6. Desamparo. 7. Estranho. I. Rudge, Ana Maria de Toledo Piza. II. Pontifícia Universidade Católica do Rio de Janeiro. Departamento de Psicologia. III. Título.

CDD: 150 


\section{Agradecimentos}

À Ana Maria Rudge, por ter acolhido o meu projeto de pesquisa, e também por sua orientação atenta e rigorosa.

À PUC-Rio, pela bolsa que me isentou do pagamento de mensalidade. Sem ela não teria conseguido realizar este curso.

Aos professores da Banca, Marco Antonio e Marcus André, por terem aceitado nosso convite.

À Manuela, pela carinhosa amizade, especialmente nos momentos mais difíceis do curso. 


\section{Resumo}

Gonçalves, Rafael Ramos; Rudge, Ana Maria de Toledo Piza. A clínica da angústia. Rio de Janeiro, 2014. 112p. Dissertação de Mestrado Departamento de Psicologia, Pontifícia Universidade Católica do Rio de Janeiro.

Esta dissertação tem como ponto de partida as considerações freudianas sobre a sexualidade como fator preponderante nas manifestações de angústia. A compreensão de que a sexualidade possui um caráter traumático torna mais explícito o fato de que a angústia está relacionada a algo que extrapola a capacidade de simbolização do psiquismo. A consideração sobre o caso Hans pretende mostrar o que está em jogo na relação entre o sexual e a angústia. A partir deste caso clínico é possível discernir que o perigo assinalado pela angústia diz respeito à castração, conceito que se destaca no comentário sobre o fenômeno do estranho, a partir do qual se compreende que o perigo assinalado pela angústia está associado à organização da imagem do corpo, não sendo apenas algo proveniente do exterior, alheio ao eu. A partir do conto de Hoffmann, "O Homem de Areia", desenvolve-se a ideia de que existe algo que está localizado numa região para além da imagem corporal, mas que ao mesmo tempo faz parte dela. Esta região ao mesmo tempo estranha e familiar é onde está localizado o objeto a, do qual a angústia é a única tradução subjetiva. A consideração sobre o lugar da angústia na direção do tratamento se apoia nesta importante noção da teoria lacaniana.

\section{Palavras-chave}

sexualidade; angústia; castração; desejo; desamparo; estranho. 


\section{Abstract}

Gonçalves, Rafael Ramos; Rudge, Ana Maria de Toledo Piza (Advisor) . The clinic of anguish. Rio de Janeiro, 2014. 112p. Msc. Dissertation Departamento de Psicologia, Pontifícia Universidade Católica do Rio de Janeiro.

The start point of this dissertation is the Freudian's considerations about sexuality like a special factor in production of anguish. The conception that sexuality is traumatic demonstrates the fact that anguish is associated with something beyond the psyche's capacity to symbolization. The approach about Hans case introduces the connection between sexuality and anguish. This clinical case shows that castration is the danger indicated by anguish. The concept of castration appears in the comments about the experience of estrangement, where it become clear that the function of anguish is associated with the body's image too. So, anguish isn't an external part of I. The story "The Sandman", written by Hoffmann, exemplifies the idea that there is something in a place not included in body's image, but that is part of its structure. The object $a$ is in that place, simultaneously strange and familiar, and its subjective expression is anguish. The study about the function of anguish on direction of treatment is sustained by the concept of object $a$, wich is very important in the theory of Lacan.

\section{Keywords}

sexuality; anguish; castration; desire; abandonment; strange. 


\section{Sumário}

$\begin{array}{ll}\text { Introdução } & 8\end{array}$

1 Angústia e sexualidade 13

1.1. A origem somática 13

1.2. O trauma sexual 21

1.3. A teoria da libido e o narcisismo 26

2 Angústia e defesa 33

2.1. Angústia realística e angústia neurótica 33

2.2. As neuroses traumáticas 38

3 Da angústia à fobia 43

3.1. O caso clínico do pequeno Hans 43

3.2. O falo e o objeto fóbico 50

3.3. Angústia, castração e desamparo 59

4 O estranho: uma porta para a angústia $\quad 67$

4.1. O eu na relação especular $\quad 67$

4.2. A inquietante estranheza $\quad 74$

4.3. Para além do imaginário 79

5 A angústia na direção do tratamento $\quad 84$

5.1. O objeto da angústia $\quad 84$

5.2. Angústia e desejo do Outro 88

5.3. A angústia de castração e o limite da análise 94

$\begin{array}{ll}\text { Conclusão } & 100\end{array}$

$\begin{array}{ll}\text { Referências } & 109\end{array}$ 


\section{Introdução}

A angústia certamente é uma experiência familiar a todas as pessoas. Já foi objeto de estudo de filósofos, material para inúmeras obras literárias, tema para

pinturas, música e teatro. É claro que outros aspectos da vida humana poderiam ser incluídos nesta listagem, o que torna necessário justificar sua escolha como objeto de estudo.

A decisão de estudar este tema foi determinada principalmente pela experiência de conduzir um tratamento psicanalítico. A frequência com que os analisandos se declaram angustiados em diversos momentos do tratamento, bem como o efeito que esta declaração provoca na relação analítica, demonstram que não é possível ficar indiferente ao valor deste afeto para a clínica. "O que fazer?", “O que dizer?” são perguntas que vêm ao encontro do sujeito angustiado. Elas podem surgir tanto do lado do analisando quanto do lado do analista, revelando ao mesmo tempo a urgência de uma resposta e a inexistência de garantia sobre ela.

Apesar do crescente esforço da ciência, principalmente a medicina psiquiátrica, para livrar os sujeitos o mais rápido possível da angústia, ela continua esnobando todas as tentativas de curá-la. Nem mesmo a religião, as filosofias orientais ou os incontáveis títulos de autoajuda conseguem indicar o caminho a percorrer para evitar o encontro com ela. A pessoa que vai ao analista talvez não tenha visitado todas estas opções, mas certamente deve ter se deparado com o fracasso que muitos experimentam ao depositar suas expectativas de felicidade naquelas alternativas. O praticante da psicanálise não deve ignorar que o sujeito angustiado vai encará-lo, a princípio, como mais uma via para a sua busca de uma resposta que seja capaz de devolver-lhe a tranquilidade e mostrar o que precisa ser feito para nunca mais se angustiar. Em síntese, pode-se dizer que o surgimento da angústia na clínica revela ao analista o surgimento de alguma coisa “estrangeira ao simbólico" (Fuks, 2001), o que coloca um desafio ao tratamento psicanalítico que tem como seu único instrumento a linguagem.

O interesse no assunto ganhou força a partir do contato com a propostam feita por Souza (2005), de que existem similaridades entre a estrutura do fenômeno da angústia e a do dispositivo analítico. Além disso, o evidente destaque dado a este afeto no desenvolvimento da teorização freudiana desperta o 
questionamento sobre a sua importância no desenvolvimento de uma análise.

Em uma passagem do seminário dedicado à transferência, Lacan (1992) se utiliza da imagem de um bando de animais quando discorre sobre o sinal da angústia. Ele comenta que existe, no reino animal, aquele indivíduo que se destaca do grupo por ter a função de representar todo o bando, sendo ele o responsável por emitir algum sinal que informe aos demais a aproximação de um predador. $\mathrm{O}$ mesmo pode ser dito a respeito do sinal de angústia:"é do alter ego, do outro que constitui seu eu que o sujeito pode recebê-lo" (Lacan,1992, p.352), do mesmo modo que o animal sentinela, alter ego da individualidade formada pelo bando de animais, também constitui o bando como um "eu" em fuga.

No campo das relações com o outro sempre existe o perigo de ameaça ao eu, razão pela qual Lacan adverte sobre o perigo do altruísmo, algo atestado pela experiência analítica e válido como referência capital para a direção do tratamento, pois o altruísmo, em suas múltiplas possibilidades de expressão, serve para ocultar algo, mais precisamente uma ameaça captada na própria imagem, em seu vínculo com o objeto do desejo. Antes mesmo de proferir o Seminário sobre a angústia ele já fazia questão de destacar que ela não pode ser reduzida à simples função de avisar sobre a necessidade de fugir de um perigo. Este aspecto é secundário. O caráter essencial da angústia está no fato de ela ser o "modo radical sob o qual é mantida a relação com o desejo" (Lacan, 1992, p.353).

O trabalho de Lacan, embora tenha algumas diferenças em relação ao de Freud, parte sempre de sua contribuição. Ele concorda com a ideia de que a angústia funciona como sinal de um perigo externo a partir do apoio de um perigo interno - o pulsional. Nesta perspectiva é possível compreender, por exemplo, que o conflito psíquico supõe que o desejo incestuoso pode resultar na perda do amor ou na castração, que constituem os perigos classificados como externos. O grande mérito de Lacan consistiu em explorar as consequências deste imbricamento entre o interno e o externo. $\mathrm{O}$ tema da angústia tem lugar privilegiado em seu esforço de elaboração sobre a existência do objeto que se aloja nesta região cujos limites são dificeis de determinar, o objeto $a$, que mantém relação ao mesmo tempo com a angústia e o desejo.

A partir das contribuições destes dois autores, esta dissertação será desenvolvida tendo como temas norteadores a sexualidade, a castração e o desejo.

É no primeiro capítulo desta dissertação que pretendo mostrar como a 
angústia foi abordada por Freud, a princípio, como efeito de uma excitação sexual somática que não encontrou vias de descarga. A relação entre angústia e sexualidade é constante na evolução do pensamento freudiano. No entanto, a concepção da sexualidade como traumática, aliada à introdução do narcisismo, abrirá o espaço para a consideração da angústia no plano psíquico, afastando-a de uma conotação meramente fisiológica.

Embora a teorização posterior sobre a angústia não enfatize tanto a sexualidade estritamente somática, é possível notar sua presença sob o selo do trauma, que pode ser tomado como significante que vincula as duas formulações sobre a angústia. É preciso discernir, no entanto, que o trauma, num primeiro momento, ou seja, até 1897, ainda está relacionado à sedução real de um adulto, responsável por uma estimulação sexual que a criança, devido à sua prematura constituição fisiológica, não poderia assimilar. Neste caso, a angústia seria o efeito do recalque de experiências sexuais de caráter traumático para o psiquismo. Após esse ano, o trauma ainda é privilegiado, mas numa relação com a fantasia. Não haveria necessariamente, portanto, uma sedução real, mas uma fantasia inconsciente de sedução, na qual o sujeito está posicionado como objeto para a satisfação do outro.

A temática do narcisismo servirá de pretexto para abordar, no segundo capítulo, a importância da angústia como sinal de defesa contra os perigos que ameaçam a organização do eu. Mas a compreensão do caráter ameaçador associado à angústia só poderá ser esclarecido a partir do estudo das neuroses traumáticas, que permitirão compreender melhor de que maneira a teoria do narcisismo pode esclarecer os processos que resultam no surgimento daquele afeto.

A partir da constatação de que a angústia diz respeito a experiências que possuem um caráter traumático, o terceiro capítulo surge como início da passagem às considerações de Lacan sobre a angústia. O caso clínico do pequeno Hans mostrou-se favorável não somente à introdução do pensamento lacaniano na dissertação, mas também como um meio de investigação sobre a incidência da angústia na clínica, estimulado pela hipótese de que existe uma relação íntima entre a angústia e o dispositivo analítico.

Os aspectos fundamentais do pensamento freudiano sobre a angústia reaparecem neste capítulo, sobretudo os que se referem à sexualidade. A fobia 
comparece como estratégia defensiva contra a angústia ocasionada pelo aumento da excitação sexual. A contribuição de Lacan é introduzida a propósito das relações entre o objeto fóbico e a presença do falo na dinâmica sexual estabelecida entre Hans e sua mãe. É neste espaço entre Hans e a mãe que a angústia surge, testemunhando tanto o caráter traumático da excitação do pênis, quanto o fato de que algo falta à mãe, algo que ele não pode mais dar a ela.

Com as contribuições de Freud e Lacan pretendo mostrar que o perigo indicado pela angústia é, fundamentalmente, um perigo vinculado à castração, que, a partir do caso Hans, torna-se uma referência importante no desenvolvimento da dissertação. No quarto capítulo, a vinculação entre a angústia e o corpo é explicitada no estudo do estádio do espelho, contribuição lacaniana que possibilita uma nova perspectiva sobre a incidência da angústia na organização do eu. Neste contexto, a castração ganha um lugar de destaque, deixando claro que o perigo assinalado pela angústia concerne à organização da imagem do corpo, não sendo apenas algo proveniente do exterior, alheio ao eu. A partir do conto de Hoffmann, "O homem de areia", desenvolve-se a ideia de que existe algo que está localizado numa região para além da imagem corporal, mas que ao mesmo tempo faz parte dela. Esta região ao mesmo tempo estranha e familiar é onde está abrigado o objeto $a$, do qual a angústia é a única tradução subjetiva (Lacan, 2005). É nesta relação estrutural entre o $a$ e a imagem corporal que se concebe a angústia como sinal no eu, que "adverte o sujeito de um perigo que é o de um desejo enigmático que envolve seu ser como perdido e passível de anulação, seu ser como objeto que pode ser, sem saber qual, para o desejo do Outro" (Vanier, 2006, p.288).

A angústia como sinal da presença do perigo representado pelo desejo do Outro é o tema que orienta o desenvolvimento do quinto capítulo. Um aspecto importante a ser destacado neste capítulo é a relação entre o objeto $a$ e a constituição do sujeito. A tese lacaniana fundamental sobre isto afirma que tanto sujeito e objeto se constituem no campo do Outro, lugar dos significantes. O resto desta divisão é precisamente o que escapa ao narcisismo e que torna possível a relação com outros objetos. Trata-se de um espaço deixado vazio por um objeto mítico que fora perdido. Segundo Fuks (2001), a angústia é abordada na obra lacaniana numa relação com os restos das primeiras experiências de satisfação, as quais não se integram nos processos de simbolização e, justamente por isso, 
impulsionam o desejo. À dimensão do resto é vinculado o objeto da angústia, por ele denominado objeto $a$, aquele que "resiste a qualquer assimilação à função do significante, e é por isso mesmo que simboliza o que, na esfera do significante, sempre se apresenta como perdido" (Lacan, 2005, p.193).

A proposta deste capítulo é mostrar como a angústia está no cerne do tratamento psicanalítico, não só porque as pessoas frequentemente chegam ao analista paralisados por este afeto, mas também porque o que impulsiona o tratamento é exatamente o que escapa ao sujeito, dando-lhe a impressão de algo estranho, que só o analista seria capaz de explicar o que é. Este "estranho" estará associado ao aparecimento de um desejo que, para Lacan, é fundamentalmente desejo do Outro, ao mesmo tempo interno e externo ao sujeito. A angústia surgida neste momento será analisada como reveladora do corte existente entre o sujeito e o Outro, no qual se coloca a dificuldade em "não saber que objeto $a$ sou" (Lacan, 2005, p.353) para o desejo do Outro, pois tal objeto, tendo sido destacado do corpo pela incidência da linguagem, não aparece na imagem que o sujeito conquista para si. A perda de gozo produzida pela entrada no campo do Outro resulta numa imagem portadora de um furo, no qual se desenha o traçado da pulsão.

A concepção lacaniana sobre a angústia põe em relevo a vacilação da estrutura psíquica surgida quando a fantasia não consegue sustentar esta relação. Ele apresenta uma compreensão inovadora do aparecimento da angústia que será desenvolvida também no último capítulo do trabalho: "a angústia não é sinal de uma falta [...] O que provoca a angústia é tudo aquilo que nos anuncia, que nos permite entrever que voltaremos ao colo" (Lacan, 2005, p.64). A impossibilidade deste retorno é o que vai permitir abordar a angústia como afeto que assinala a insuperável distância entre o desejo e o objeto que sempre falta, e o quanto é ameaçadora para o sujeito a tentativa de eliminá-la. O perigo, aqui, é a perda da dimensão da falta como constituinte do sujeito do desejo, a qual pode resultar em dissolução subjetiva e, se o sujeito estiver em transferência, na interrupção do tratamento. É imprescindível abordar a relação com o desejo para tentar extrair a importância da angústia na condução do tratamento, pois, como observa Vieira (2001), é "na passagem da angústia ao desejo que se funda a experiência analítica" (p.141). 


\section{1 \\ Angústia e sexualidade}

\section{1.}

\section{A origem somática}

Inicialmente, a angústia foi um tema abordado no contexto da descrição de um novo tipo clínico denominado "neurose de angústia", inscrita no quadro das neuroses atuais, do qual faziam parte também a neurastenia e a hipocondria. Sua manifestação era descrita como resultado de alguma perturbação na esfera da sexualidade, responsável pela produção de um estado em que a excitação sexual somática não podia ser inscrita psiquicamente. Neste sentido, a neurose de angústia introduziu no campo da teorização psicanalítica nascente um limite ao paradigma da representação psíquica dominante na teoria até 1920, quando esta dimensão do que não se inscreve no psiquismo será objeto da elaboração metapsicológica (Campos, 2004).

A convicção de que a angústia tinha alguma relação com a atividade sexual nasceu do atendimento de pacientes em que o desencadeamento dos sintomas neuróticos era antecedido da prática do coito interrompido. A predominância desta condição parecia sugerir que os sintomas da neurose de angústia seriam um prolongamento das sensações experimentadas no ato sexual, sobretudo aquelas que se faziam presentes quando havia preocupação com a gravidez. Haveria, segundo esta interpretação, uma qualidade histérica nos sintomas de neurose de angústia, ou seja, eles seriam reminiscências da experiência de angústia vivida durante o ato sexual. Contudo, a observação de que pessoas sem preocupação com a gravidez também desenvolviam neurose de angústia indicava que tal vivência não poderia ser considerada uma lembrança de momentos angustiantes, como aqueles em que se experimenta o receio com a gravidez.

Existe um dado importante encontrado no Rascunho E (Freud, 1894/1980) que indica claramente o argumento predominante nas primeiras 
formulações sobre a angústia. Trata-se da descoberta de que a neurose de angústia acometia tanto as mulheres comprovadamente frígidas quanto aquelas que tinham sensibilidade sexual. Este fato levou Freud a concluir que a angústia só poderia ser produzida por um fator somático ligado à vida sexual, e não da esfera psíquica.

A fim de identificar qual seria este fator, Freud (1895a/1980) produziu uma listagem de alguns incidentes que podem acarretar angústia, como a abstinência sexual voluntária, coito interrompido, encontro com o sexo na adolescência etc. A reunião destes casos revelou a existência de dois aspectos comuns a todos eles: um acúmulo de excitação somática e a inexistência de determinantes psíquicos. Estas características foram fundamentais para o estabelecimento de um limite entre a neurose de angústia e as psiconeuroses, que também eram alvos de seu interesse neste período. Tal separação fica nítida quando se considera que a neurose de angústia não é provocada por um terror (Schreck), por exemplo, que justificaria a disposição para os sintomas de angústia: "A histeria ou uma neurose traumática podem ser adquiridas em decorrência de um único terror, mas nunca a neurose de angústia” (Freud, 1895a/1980, p.126). De modo análogo, observa-se que o medo - um fato psíquico - de que o coito interrompido falhe, possibilitando, consequentemente, a gravidez, não é o fator decisivo para o surgimento da neurose de angústia. A neurose de angústia se configura como uma "neurose de represamento" produzida pelo impedimento da descarga de tensão sexual somática. A angústia, portanto, não está contida na tensão represada, mas ela corresponde à transformação desta tensão (Freud, 1894/1980, p.264), sem a mediação da atividade psíquica.

Embora considere o fator sexual como algo preponderante, a esfera psíquica não foi completamente desprezada. Mas é preciso destacar que a neurose de angústia é sempre acompanhada de um decréscimo da libido sexual - que é de natureza psíquica - , razão pela qual os pacientes não são capazes de compreender que sua enfermidade tenha relação com uma insatisfação sexual, pois estão fortemente conscientes de que no período em que se encontram acometidos pela neurose o interesse sexual está ausente. Embora não exista gênese psíquica, a angústia, gerada a partir de uma excitação somática, provoca o

decréscimo da participação psíquica nos processos sexuais - todas essas indicações, dizia eu, levam-nos a esperar que o mecanismo da neurose de angústia deva ser procurado em uma deflexão da excitação sexual somática da 
esfera psíquica, com um consequente emprego anormal dessa excitação" (Freud, 1895a/1980, p.126, grifo do autor).

Somente mais tarde, na sinopse deste texto, Freud (1897/1980) fornecerá uma descrição lapidar do que resulta deste "emprego anormal da excitação": "A neurose de angústia é a libido sexual transformada" (p.278). Neste momento de sua teoria, a angústia é um afeto produzido pela transformação da libido, o que não é a mesma coisa que dizer "transformação da tensão". No Rascunho E já se podia encontrar uma preocupação de Freud em esclarecer estes termos. Ele mesmo se questiona sobra a razão por que ocorre uma transformação da tensão em angústia. É a partir deste questionamento que ele passa a analisar o que ocorre a partir da excitação provocada pelo instinto sexual. Ele considera que a excitação pode sofrer variações, mas só pode ser percebida quando atinge um determinado limiar que, ao ser ultrapassado, pode adquirir alguma "significação psíquica", o que nada mais é do que a ligação desta excitação com algum agrupamento de ideias que permitirão a busca de alguma ação capaz de descarregar a tensão: "Assim, a tensão sexual física acima de certo nível desperta a libido psíquica, que então induz ao coito etc" (Freud, 1894/1980, p.265). O que se observa na neurose de angústia é que a tensão sexual somática aumenta, atinge o referido limiar capaz de despertar um afeto psíquico, mas isto não é suficiente para formar um afeto sexual, ou seja, uma inscrição do sexual - até então estritamente somático - no psíquico. Somente neste momento a tensão sexual somática, por não ter sido psiquicamente ligada, transforma-se em angústia. A transformação, portanto, é consequência do fracasso no curso da conexão psíquica.

O que resulta desse processo é uma descarga da tensão no corpo, produzindo as alterações típicas deste quadro, como palpitações, tremores, dificuldade para respirar etc. Freud (1895a/1980) esclarece este processo recorrendo ao funcionamento sexual no homem, destacando que a contínua excitação sexual é transferida do soma até o aparelho psíquico, onde consegue se expressar como estímulo psíquico. Deste modo, as ideias de caráter sexual se tornam investidas de energia, produzindo uma tensão que só pode ser descarregada através de uma "ação específica ou adequada" (p.127). A neurose de angústia resultaria do impedimento na realização desta assimilação psíquica da excitação somática, fazendo com que esta tenha um destino inadequado. É importante observar que alguma descarga é possível; afinal, é como alternativa à 
dificuldade para escoar a libido no plano psíquico que a angústia aparece. Tornase compreensível, então, porque ele entende "os sintomas da neurose de angústia como sendo, em certo sentido, substitutos da omitida ação específica, subsequente à excitação sexual" (p.130). Esta é uma diferença importante em relação à neurastenia, cuja etiologia também está associada à sexualidade. Ao contrário da neurose de angústia, a neurastenia consegue realizar uma ação de descarga, ainda que menos adequada, como a substituição do ato sexual pela masturbação, por exemplo.

É importante perceber que a separação entre neurastenia e neurose de angústia não foi gratuita. Havia muitos sintomas que não cabiam no primeiro tipo clínico e que de certo modo revelam uma constituição muito particular. Um destes sintomas é a irritabilidade geral, muito comum no quadro dos sintomas que compõem a neurose de angústia. O sintoma da irritabilidade tem importância teórica que merece reconhecimento, pois permitiu a Freud (1895a/1980) perceber que a irritação estava relacionada ao acúmulo de excitação ou à dificuldade para lidar com ela. Um curioso efeito deste estado é a hiperestesia auditiva, ou seja, um aumento de sensibilidade aos ruídos do meio, que contribui significativamente para o estabelecimento do estado de terror que acomete alguns pacientes.

A correlação entre uma experiência capaz de causar terror e a neurose de angústia de certo modo aparece no outro sintoma apresentado no mesmo artigo: $a$ expectativa ansiosa. Os exemplos apresentados são eloquentes do ponto de vista teórico e também são clinicamente muito instrutivos: a mulher que pensa em uma pneumonia fatal quando o marido gripado tosse, ou a pessoa que, ao ouvir baterem à porta, imagina que alguém traz uma notícia ruim. Tal fenômeno constitui, em sua opinião, o "sintoma nuclear da neurose" (Freud 1895a/1980, p.110), pois indica a presença de um quantum de angústia em estado livre que pode ser empregado quando uma ideia adequada aparece. No caso da mulher zelosa pela saúde do marido, provavelmente já existia angústia disponível com a qual ela não conseguia lidar, suscitada pela gripe que ele havia contraído.

Quando nenhum encadeamento de ideias é possível, fica difícil lidar com as situações geradoras de angústia, fazendo com que esta invada a consciência e produza um ataque de angústia. Nestes casos pode existir apenas um sentimento de angústia ou então uma tentativa de interpretação, como a ideia de extinção da vida, a ideia de que a qualquer momento poderá sofrer um acidente ou o medo de 
enlouquecer, queixa muito comum nos consultórios. Frequentemente, na descrição deste estado, destacam-se os distúrbios corporais vinculados ao sentimento de angústia, tais como a dificuldade respiratória, suor e alterações no batimento cardíaco. Deste modo, o sentimento de angústia "se recolhe ao fundo, ou é referido de modo bastante irreconhecível, tal como 'sentir-se mal', 'não estar à vontade', e assim por diante" (Freud, 1895a/1980, p.111). Fica evidente, neste exemplos, como a descarga por vias somáticas que caracteriza a angústia funciona como um meio de processar o excesso de tensão que não consegue encontrar uma ideia adequada para se ligar.

Associados à expectativa ansiosa e à tendência ao desenvolvimento de ataques de angústia, há dois grupos de fobias. Um deles relacionado a riscos fisiológicos e o outro, à locomoção. No primeiro podem ser incluídos tanto o medo de cobras, tempestades, escuridão, quanto o escrúpulo moral: "o que torna essas experiências importantes, e sua lembrança duradoura, é afinal apenas a angústia que pode emergir no momento [da experiência] e que, da mesma maneira, pode emergir agora. Em outras palavras, tais impressões permanecem poderosas apenas em pessoas com 'expectativa ansiosa'" (Freud, 1895a/1980, p.114). Já a agorafobia representa o tipo de fobia ligado à locomoção, que frequentemente é precedida por um ataque de vertigem que só se torna efetivamente um impedimento à locomoção quando é acompanhada pela angústia.

A aproximação entre angústia e fobia denota o quanto aquele afeto já está incluído nas preocupações freudianas relativas às ameaças ao funcionamento do psiquismo e aos mecanismos defensivos empregados para manter sua integridade. Destaca-se em meio às considerações sobre este assunto uma ideia que pode ser considerada bastante sofisticada para este momento da teoria, sobretudo por suas implicações clínicas. Trata-se da observação de que na neurose de angústia o afeto não tem origem em uma ideia recalcada e não pode ser "posteriormente redutível pela análise psicológica, nem equacionável pela psicoterapia” (Freud, 1895a/1980, p.114, grifo do autor). Não há, portanto, substituição de uma ideia ameaçadora por outra inofensiva, pois o afeto não é gerado por conflitos de ideias, mas por um fator estrangeiro ao psiquismo. Este fato pode ser percebido quando se observa que é comum o emprego de "medidas protetoras" adotadas no momento do aparecimento da fobia como estratégia para manter afastada a angústia. Freud cita, por exemplo, a "mania especulativa", resultante do esforço 
para contrariar a sugestão de que é louco, resultante da fobia hipocondríaca, ou a "mania de duvidar", produzida pela constante dúvida sobre o curso do próprio pensamento.

Acompanhando a evolução da teoria freudiana, é possível observar como a problemática do terror (e medo) se aproxima da questão do sexual. Esta afinidade entre os temas foi o principal motivo da redação de um artigo no qual Freud (1895c/1980) responde à crítica dirigida por Löwenfeld à etiologia sexual da neurose de angústia. O principal argumento deste autor contra a tese freudiana é extraído de um caso clínico no qual a paciente apresentou estados de angústia após passar por uma experiência de terror, contrariando a convicção freudiana de que a neurose de angústia não se origina de um único terror. Tratava-se de uma mulher submetida a um parto difícil no ano que antecedeu seu casamento. Poucas semanas depois ficou assustada com o adoecimento do marido, o que a fez correr apenas de camisola pelo cômodo, expondo-se ao frio. A partir deste momento ela apresentou estados de angústia ao entardecer, acompanhados de tremor, evoluindo para um quadro de fobia. Löwenfeld tomou este caso como prova irrefutável de que é possível a ocorrência de neurose de angústia com origem psíquica, produzida pelo terror. Freud acolhe elegantemente a crítica do colega e concorda com o fato de que um "choque psíquico" pode ocasionar angústia, mas observa que não é necessário que o terror ou a expectativa ansiosa tenham parte na etiologia. É possível, por exemplo, que o estado de angústia apareça ao receber a notícia do falecimento de um parente ou por se preocupar com a saúde de alguém.

Sua concordância revela que o problema da crítica não está na ocorrência do terror, mas sim na interpretação de sua influência na produção da angústia. $\mathrm{O}$ fundamento de sua réplica consiste na ideia de que nem sempre a causa final, desencadeante, pode ser tomada como causa efficiens. Para ilustrar, considera o papel de um trauma no ataque de gota. É inadmissível que o trauma tenha causado a gota; na verdade, ela foi apenas um agente provocador. Neste caso, ele considera o trauma um "fator banal" e inclui neste tipo de fator o terror, emoção tão importante para o argumento de Löwenfeld: "o terror pode provocar coreia, apoplexia, paralisia agitante e muitas outras coisas, assim como pode provocar a neurose de angústia" (Freud, 1895c/1980, p.147). Se o terror é apenas um agente provocador, capaz de provocar, inclusive, outras doenças, não há razão, de fato, 
para excluir tão facilmente a etiologia sexual na constituição da neurose de angústia.

Em benefício de uma exposição sistemática da etiologia da neurose da angústia, ficou estabelecido o seguinte postulado: "existe um fator etiológico específico para a neurose de angústia que pode ser substituído em sua operação por uma perturbação banal em sentido QUANTITATIVO, mas não em sentido QUALITATIVO” (Freud, 1895c/1980, p.151, grifo do autor). A este postulado foram adicionados quatro componentes admitidos como típicos da etiologia das neuroses: precondição, causa específica, causas concorrentes e causa precipitante. Em conjunto eles formam o alicerce da conclusão de sua resposta a Löwenfeld. A importância desta divisão para o seu argumento fica evidente quando se analisa cada uma. A precondição diz respeito a fatores cuja ausência impede a manifestação do efeito, embora não sejam suficientes para provocá-lo. A precondição, portanto, não se confunde com a causa específica, que é justamente aquela que está sempre presente quando o efeito ocorre. As causas concorrentes são os fatores que nem sempre estão presentes, mas que colaboram com a precondição e com a causa específica para a produção do efeito. A causa precipitante é a que aparece por último na equação e é responsável pelo desencadeamento. No que diz respeito à neurose de angústia, a causa específica é sempre o fator sexual. A equação etiológica apresentada neste artigo se mostra perfeitamente conciliável com o aparecimento do terror como causa de uma neurose de angústia. Fica especificado, no entanto, que o terror, emoção, ou até mesmo uma estafa, participam como causas concorrentes (ou auxiliares), evidenciado-se, deste modo, o equívoco da crítica etiologia sexual da neurose de angústia.

É notável como a clínica revelou aos poucos a predominância do sexual. Neste período este tema aparecia como uma imposição do trabalho com os pacientes. A neurose de angústia se mostrava como uma espécie de exacerbação das dificuldades surgidas da relação com o exercício da sexualidade, ensinando que o psicanalista precisa estar atento às nuances das manifestações deste aspecto. O contato com casos em que predominavam sintomas de angústia certamente contribuíram para que o interesse de Freud por este assunto crescesse. Afinal, qual é o alcance da relação entre angústia e desempenho sexual? À medida que percebia o conjunto de implicações clínicas colocadas pela neurose de angústia, 
ficou evidente a força do sexual no funcionamento do psiquismo e o quanto ela pode perturbar quando não é adequadamente abordada. 


\section{2.}

O trauma sexual

A todo momento, na teorização inicial sobre a angústia, se percebe que o incremento da tensão somática ocorre em função de alguma falha na execução de um ato capaz de proporcionar alívio. Esta relação entre o aumento da tensão e a execução de uma ação de descarga já estava presente no Projeto, texto em que Freud (1895d/1980) desenvolve a ideia de que a experiência de satisfação consiste na eliminação de um aumento de tensão no aparelho psíquico. De acordo com esta teoria, a crescente complexidade do organismo faz com que o sistema nervoso tenha que lidar também com estímulos provenientes do interior do organismo, responsáveis pela experiência das necessidades básicas, como fome, respiração e sexualidade, aos quais os movimentos reflexos, que acompanham o ser humano desde os primeiros instantes de vida, não são capazes de responder de maneira adequada. Uma alternativa para eliminar tais estímulos seria alguma "alteração interna" capaz de produzir a descarga, como grito ou inervação vascular, mas estas também se revelam insuficientes, pois não conseguem cessar a estimulação endógena. Ao contrário do movimento reflexo como fuga do estimulo, cuja realização ocorre pela descarga para os músculos de uma parcela de energia retidas nos neurônios, a alteração interna, ainda que produza alguma descarga pela via motora, como o grito, não consegue abolir o estímulo. A anulação deste estímulo, portanto, só pode ser efetuada por uma ação externa. No entanto, "o organismo humano é, a princípio, incapaz de levar a cabo essa ação específica. Ela se efetua por meio da assistência alheia, quando a atenção de uma pessoa experiente é atraída para o estado em que se encontra a criança" (Freud,1895d/1980, p.422) em virtude do grito ou choro, descargas obtidas por meio da alteração interna.

A percepção da importância do corpo na descrição do fenômeno da angústia é favorecida desde o início das pesquisas freudianas pela observação dos sintomas histéricos. O caráter conflituoso dos sintomas analisados revelavam a presença da satisfação sexual como algo que deve permanecer afastado da consciência. Segundo Conté (1995), a constituição do sintoma como satisfação substitutiva demonstra que existe um obstáculo à obtenção de uma satisfação 
direta e que este obstáculo não pode ser considerado como algo contingente mas como prova de que a sexualidade é algo que "se furta irredutivelmente ao sujeito em seu esforço de se realizar, e o marca com uma não realização, uma falha, um limite, que devem ser reconhecidos como constitutivos da própria subjetividade" (Conté, 1995, p.77). Este ponto de vista permite ressaltar também que a existência deste limite é experimentada desde as primeiras experiências de satisfação da criança. A resposta da mãe ao seu choro inaugura uma relação que a investigação freudiana demonstrou ser composta também de uma dimensão sexual aliada à satisfação das necessidades. É neste contexto, em que se descobre que não existe uma correspondência entre a satisfação da necessidade e o anseio sexual - que é uma força constante - que a noção de trauma foi introduzida como aquilo que não pode ser representado pela criança. Neste caso, o sexual precocemente apresenta seu caráter de estranheza e excesso de modo muito intenso, o que deu margem à suposição de que o surgimento de uma excitação deste tipo na criança só poderia ser resultado da sedução de um adulto.

A ideia de que o trauma foi causado por uma ação intencional de um adulto coloca a criança numa posição de vítima, como se a excitação sexual fosse realmente uma característica que não poderia estar presente nela senão como algo introduzido à força. O privilégio concedido ao aspecto subjetivo do trauma na produção dos sintomas, em detrimento do acontecimento real, foi o que possibilitou dar ao corpo, e portanto, à sexualidade, um novo estatuto, deslocando a clínica do campo da fisiologia para o da psicologia e proporcionando novas descobertas sobre o funcionamento do psiquismo. Tal deslocamento não teria sido possível sem a noção de libido, cujo valor para a teorização a respeito do trauma é inegável. Com a noção de libido Freud se afasta da concepção médica sobre o trauma dominante na época e introduz a dimensão de uma economia psíquica responsável pela produção dos sintomas. Deste modo, o trauma deixa de ser apenas algo associado a uma violência sobre o corpo e passa a ter uma vinculação íntima com o modo pelo qual o acontecimento com potencial traumático é assimilado pelo sujeito.

Os processos psíquicos fundamentais envolvidos no efeito traumático já estavam definidas nos primeiros textos freudianos, dedicados às neuropsicoses de defesa. O estudo sobre o mecanismo de formação da histeria evidenciou que a estratégia empregada pelo eu para se livrar de uma representação incompatível 
consiste em separá-la do afeto que investe a ideia. Privada desta "soma de excitação", outra expressão para designar o afeto, a associação com outras ideias fica interrompida, salvando o eu do conflito. Contudo, algo precisa ser feito com o afeto liberado. A maneira como o afeto for utilizado determinará as diferentes formas de neuropsicoses: histeria, quando o afeto sofre o processo de conversão, isto é, a descarga para o corpo por meio de alguma inervação motora ou sensorial associada à experiência traumática; obsessões e fobias, quando ele sofre deslocamento para novas ideias; psicose alucinatória, quando a representação e o afeto são rejeitados e paranoia, quando a excitação não é descarregada mas fica vinculada a um objeto externo (Freud, 1894b/1980).

A referência à neurose obsessiva oferece a oportunidade para indicar a importância da sexualidade e seu caráter traumático. Chama a atenção nestes casos o quanto o sexual é problemático, o que se evidencia no rechaço pelos pacientes de sua importância na determinação da neuroses. Isto ocorre porque a separação da ideia sexual de seu afeto é um processo que ocorre fora do alcance da consciência. O papel de destaque concedido ao corpo reaparece dois anos depois, em outro trabalho dedicado às neuropsicoses de defesa. Nele, Freud (1896/1980) analisa a etiologia da histeria e da neurose obsessiva, e defende a tese de que o surgimento da histeria é provocado por um trauma sexual que deve "consistir na irritação real dos genitais" (p.188) antes da puberdade; quanto à neurose obsessiva, observa que seus sintomas têm origem em "algum ato sexual executado com prazer na infância" (p.194). Em ambos os casos existe uma excitação somática prévia cujos efeitos ainda influenciam o psiquismo. Talvez por esta razão ele avalia que não é vantajoso fazer a transposição do afeto para outra ideia, pois ele continuará atuante na esfera psíquica, exigindo a conexão com uma ideia mais adequada ${ }^{1}$. A conexão do afeto com uma ideia tolerável é o que possibilita vincular a angústia liberada por algum fator sexual às "fobias primárias comuns da espécie humana quanto a animais, tempestades, escuridão" (Freud,

1 As análises desenvolvidas nos dois textos mencionados neste parágrafo estão alicerçados numa hipótese fundamental: "nas funções mentais deve ser distinguida alguma coisa - uma quota de afeto ou soma de excitação - que apresenta todas as características de uma quantidade (embora não disponhamos de meios para medi-la), capaz de crescimento, diminuição, deslocamento e descarga, e que se espalha sobre os traços de memória das ideias, tal como uma carga elétrica se expande na superfície de um corpo" (Freud, 1894/1980, p.73). Esta hipótese estará presente em toda a construção teórica posterior e, em particular, nos trabalhos sobre a angústia. 
1894/1980, p.67) ou então a outras ideias cuja vinculação com o sexual parece ainda mais distante, como aquelas ligadas à micção, sujeira e defecação.

Existem outros sintomas também descritos como efeitos de experiências de caráter traumático: paralisia, convulsões, vômitos, anorexia, alucinações visuais são alguns dos sintomas de longa duração que permitiram supor a participação de um fato da infância na constituição deles. É importante observar que tanto para estes casos, em que de fato ocorreu algum evento desencadeador da neurose, quanto em outros, nos quais opera apenas uma relação de causalidade simbólica (vômitos desencadeados por uma repulsa moral, por exemplo), fica evidente que o elemento importante não é o evento físico, mas a maneira como este evento é assimilado no psiquismo: "qualquer experiência que possa evocar emoções aflitivas - tais como as de susto, angústia, vergonha ou dor física - pode atuar como um [trauma psíquico]" (Freud, 1893/1980, p.46).

O psicanalista deve se orientar sobretudo para a realidade psíquica na consideração sobre o trauma, ainda que o evento seja objetivo, como um acidente de carro ou uma dor física. Ao fazer isso, segundo Rudge (2009), Freud não pretende incitar o desprezo pela realidade material. Na verdade, sua concepção sobre a realidade ensina que a "psicanálise precisa levar em conta o que tem valor de realidade para um sujeito" (Rudge, 2009, p.25), o que ajuda a entender por que certos eventos podem traumatizar alguns sujeitos e não outros. A ocorrência do trauma torna-se um evento indissociável da influência da fantasia, construída para lidar com um trauma fundamental: a sexualidade. Segundo a autora, embora a fantasia tenha adquirido maior importância como fator etiológico das neuroses, juntamente com a sexualidade infantil, a ideia de uma sedução em momento precoce na vida da criança foi mantida por muitos teóricos "não apenas como trauma conjuntural, como seria no caso do abuso sexual da criança, mas também como trauma necessário, que comparece na própria estruturação de toda subjetividade" (Rudge, 2009, p.27).

Esta nova concepção sobre o trauma será determinante para o desenvolvimento da segunda teoria da angústia, desenvolvida por Freud em 1926. Antes de considerar este assunto, porém, é importante analisar o reaparecimento da noção de trauma na obra freudiana em 1920, em função do desafio clínico imposto pelas neuroses traumáticas, que desafiavam o modelo de tratamento vigente, orientado pelo referencial da fantasia. Nos casos atendidos por Freud 
naquele momento, o princípio do prazer, em algumas condições, ficava aparentemente inativo, "obrigando o aparelho psíquico a realizar uma tarefa mais urgente 'além do princípio do prazer', tarefa que consiste em ligar as excitações de forma a permitir ulteriormente sua descarga" (Laplanche \& Pontalis, 2001, p.526). Tais casos evidenciaram o quanto as condições para o funcionamento do princípio do prazer são prejudicadas pelo traumatismo, o que não significa apenas uma "simples perturbação da economia libidinal" mas sim algo que "vem mais radicalmente ameaçar a integridade do sujeito" (Idem, p.526). O trauma, a partir deste momento, surge na teoria como referência que vincula aspectos relativos tanto à origem do sujeito quanto à possibilidade de sua destituição. 


\section{3. \\ A teoria da libido e o narcisismo}

A primeira sistematização da concepção psicanalítica da sexualidade veio à luz em 1905, sendo apresentada em seu caráter problemático em relação ao senso comum, pois a clínica das neuroses havia revelado que a sexualidade na verdade é fundamentalmente perversa. $\mathrm{O}$ caráter perverso da sexualidade humana pode ser verificado no modo como as manifestações do inconsciente revestem de qualidade sexual as mais variadas partes do corpo, entre as quais se destacam a mucosa da boca e do ânus, regiões que aparecem frequentemente como equivalentes dos órgãos genitais. As zonas erógenas do corpo podem formar-se em lugares que originalmente não possuem nenhuma relação com a função sexual. A excitação sexual destas zonas tem como efeito estimular o trabalho psíquico de significação sexual não só de partes do corpo mas também de qualquer outro tipo de objeto. É interessante notar como Freud constrói aos poucos uma teoria rigorosa sobre as condições que possibilitam o intercâmbio sexual adulto, definindo aspectos do desenvolvimento infantil bastante expressivos a respeito da relação com o outro.

Isto fica evidente no estudo das primeiras experiências da criança, onde se pode perceber a íntima relação existente entre as pulsões sexuais e a ingestão de alimentos. Neste momento, o que importa é apenas o seio da mãe. Somente depois, quando este objeto é perdido, é possível formar alguma ideia sobre quem lhe fornecia o órgão de onde retirava seu alimento; o resultado desta perda de objeto é o estabelecimento da pulsão sexual como auto-erótica, inicialmente. Freud considera que a sucção do seio da mãe é o protótipo de toda relação amorosa e de certo modo uma referência insuperável da busca futura por novos objetos. Após superar o momento em que as expressões de sua atividade sexual estão predominantemente associadas à presença materna, a criança continuará nutrindo por todas as pessoas que a "auxiliam em seu desamparo e satisfazem suas necessidades" (Freud, 1905/1980, p.229) um amor equivalente ao que experimentava no inicio da vida. A raiz deste amor, portanto, é a satisfação de cunho sexual que a criança experimentou quando recebia beijos, carícias ou escutava a voz materna durante os cuidados recebidos, tais como alimentação, 
banho ou a preparação para dormir.

Ao abordar a angústia infantil, Freud reitera o caráter de "amor sexual" das relações entre as crianças e seus cuidadores para depois afirmar que a angústia infantil "nada mais é que uma expressão do fato de sentirem a perda da pessoa que amam. É por este motivo que ficam assustadas diante de qualquer estranho" (Freud, 1905/1980, p.231). O mesmo argumento serve para demonstrar que as crianças se assustam na escuridão porque ficam impedidas de ver a pessoa que amam. Freud recusa a ideia de que este tipo de reação seria típica apenas em crianças mais sensíveis por causa da timidez. Aqui se evoca o fator sexual como referência que permite mostrar que nem sempre este tipo de reação à perda do objeto amoroso pode ser atribuída a um aspecto da personalidade. O que é decisivo é a pulsão sexual: as crianças tímidas são aquelas que desenvolveram uma pulsão sexual excessiva. Deste modo, a criança (tímida) que transforma a libido insatisfeita em angústia, comporta-se como adulto, enquanto o adulto neurótico em virtude da insatisfação da libido se comporta como criança: "começa a assustar-se quando está sozinho, isto é, quando está afastado de alguém de cujo amor se sentira seguro, e busca minorar este medo através dos expedientes mais infantis" (p.231). Não se deve acreditar que as histórias aterrorizantes estejam na origem da angústia infantil, mas sim as condições de satisfação da pulsão sexual.

Se as primeiras elaborações freudianas sobre a angústia davam ênfase às excitações somáticas, a temática da angústia infantil introduz na investigação sobre este tema a perspectiva da relação com o objeto sexual, situado fora do corpo da criança, mas ao mesmo tempo implicando-o (Kauffman, 1996). Em seu esforço de teorização sobre o funcionamento da libido na relação com os objetos, Freud (1914/1980) adota como ponto de partida a ideia de que existe um investimento libidinal originalmente voltado para o eu, que só posteriormente se orienta aos objetos. Há uma antítese entre libido do eu e dos objetos, de tal modo que o emprego de uma resulta no decréscimo da outra. Tal distinção, no entanto, é inviável no estado do narcisismo, no qual estão conjugadas. Somente quando há investimento sobre objetos torna-se possível discriminar a energia sexual - libido - da energia que investe o eu. Aqui surge uma dificuldade no que diz respeito à diferenciação entre duas modalidades de investimento, agravada pela ambiguidade entre as noções de narcisismo e de auto-erotismo, já descrita, em 1905, como um estado inicial da libido. Além disso, o fato de localizar no eu um investimento 
inicial coloca em questão a necessidade de superar a diferenciação entre libido sexual e uma energia não sexual voltada para o eu.

Freud (1914/1980), no texto dedicado ao narcisismo, esclarece que o autoerotismo é anterior ao narcisismo, no sentido em que o investimento autoerótico já existe antes mesmo da constituição do eu. Este só se forma a partir de uma nova ação psíquica, pela qual se faz a passagem deste estado indiferenciado do eu para uma condição em que ele se diferencia do que é não-eu. A rigor, o narcisismo é o resultado do investimento libidinal do eu, dando origem à libido narcísica. Neste novo momento teórico, a antiga divisão entre as pulsões do eu e as pulsões sexuais é ameaçada, embora não de forma explícita. Se, antes, as pulsões sexuais se dirigiam apenas aos objetos, a partir do narcisismo o eu também se torna passível de investimento sexual. O eu se torna um objeto importante na teoria psicanalítica a partir do momento em que ficou estabelecida a diferença entre libido objetal e libido narcísica.

A temática do narcisismo é imprescindível para a compreensão psicanalítica sobre a relação do eu com os objetos, nos quais se incluem as pessoas com quem o bebê se relaciona desde os primeiros momentos da vida. $\mathrm{O}$ esclarecimento desta relação, por sua vez, é um passo necessário à abordagem do fenômeno da angústia tanto em Freud quanto em Lacan. Só foi possível deslocar a análise da angústia da perspectiva puramente energética à medida que a teoria pulsional ganhou uma elaboração mais precisa $^{2}$, demarcando sua diferença em relação ao domínio da satisfação das necessidades naturais. A principal característica da necessidade consiste na existência de um objeto capaz de satisfazê-la, ao contrário da pulsão, que pode se utilizar de uma variedade ilimitada de objetos para obter sua satisfação. Acentuar esta diferença é importante para afastar a possibilidade de considerar a primordial relação entre a mãe e criança, onde as primeiras experiências de satisfação ocorrem, como algo

2 De acordo com Elia (1995), o conceito de narcisismo, ao propiciar a superação do primeiro esquema pulsional, realiza um avanço análogo ao ocorrido em relação à concepção do eu no campo da filosofia. No plano metodológico, pode-se dizer que o eu em Freud não era pensável, assim como na filosofia pré-cartesiana, em que o pensamento era algo distinto do ser, não havendo a possibilidade de o pensamento pensar a si mesmo, e por isso o eu, na teoria psicanalítica, tinha que "ser suposto, e oposto ao sexual, que, pelo mesmo raciocínio, ocupava o lugar análogo ao do ser na filosofia, aquilo que era pensável por Freud" (p.119). No plano conceitual este autor considera que a primeira teoria pulsional era pré-hegeliana, pois não contemplava a temática da constituição do sujeito, introduzida por este filósofo a partir da noção de "desejo antropógeno" ou humanizador, que é diferente do desejo natural, muito próximo da noção de necessidade. 
em que as necessidades da criança pudessem ser previstas pela mãe segundo uma determinação natural que garantiria a ela a certeza do que precisa ser feito para oferecer a satisfação buscada. É o narcisismo que permite a passagem das pulsões de autoconservação para um outro regime em que predomina a relação com o outro mediante o investimento libidinal. É a partir da alteridade encarnada pela mãe que o corpo da criança recebe as condições para que o eu se forme.

A constituição do narcisismo será decisiva para a abordagem psicanalítica sobre as relações do eu com um campo de alteridade que ultrapassa o limite do contato com os pais. O gradual contato com as demandas ligadas À educação e as limitações aos impulsos libidinais exercerá uma influência importante na mitigação do narcisismo infantil. A especificidade do mecanismo do recalque como defesa permitiu a Freud situar o desaparecimento da megalomania infantil como resultado do inevitável conflito entre os impulsos libidinais e os ideais da cultura. Isto ocorre na medida em que o sujeito assume um ideal, ou seja, aquilo que o faria amável aos olhos dos pais, que sirva de referência para o eu. Esta mudança é descrita como uma transição do narcisismo infantil para uma nova modalidade de eu, plasmada por ideais incorporados pelo sujeito à medida que seu relacionamento com seus cuidadores se desenvolve:

[...] o homem se mostra incapaz de abrir mão de uma satisfação de que outrora desfrutou. Ele não está disposto a renunciar à perfeição narcisista de sua infância; e quando, ao crescer, se vê perturbado pelas admoestações de terceiros e pelo despertar de seu próprio julgamento crítico, de modo a não mais poder reter aquela perfeição, procura recuperá-la sob a nova forma de um eu ideal (Freud, 1914/1980, p.111).

Esta forma substitutiva do narcisismo infantil suscita a busca intensificada por objetos capazes de proporcionar a satisfação mais próxima possível da que foi perdida. A constituição de um ideal do eu, contudo, também representa um obstáculo. Em dois momentos do texto isso fica claro. Num deles Freud (1914/1980) afirma que a formação de um ideal aumenta as exigências sobre o eu, restringindo os investimentos libidinais. Em outro momento introduz a ideia de que o afastamento do narcisismo primário, responsável pelo desenvolvimento do eu, é provocado pelo "deslocamento da libido em direção a um ideal do eu vindo de fora, sendo a satisfação provocada pela realização desse ideal” (p.117). Ainda que o ideal do eu imponha condições à satisfação da libido objetal, nos casos em que uma pessoa está apaixonada isto não ocorre da mesma 
forma. Nesta condição, o objeto sexual se converte em um ideal sexual, servindo, portanto, às aspirações infantis na esfera do amor. $\mathrm{O}$ amor decorrente desta relação será do tipo narcisista, isto é, o sujeito amará no outro aquilo que um dia foi, que é ou que gostaria de ser, quando o objeto possui as qualidades que jamais teve. O ideal do eu e o ideal sexual estabelecem uma relação de cooperação: "o que possui a excelência que falta ao eu para torná-lo ideal é amado" (Freud, 1914/1980, p.118). Esta descoberta traz uma importante contribuição para a clínica da neurose ao mostrar que a eleição de um ideal sexual segundo uma orientação narcisista é a estratégia empregada para recuperar os investimentos libidinais do eu, dele retiradas em virtude da perturbação causada por "tendências sexuais que já não estão sujeitas a controle" (Freud, 1914/1980, p.116).

A dificuldade em lidar com as perturbações do narcisismo está relacionada também ao problema do "complexo de castração", que se localiza precisamente no cerne das relações entre a criança e seus genitores. A entrada no circuito das relações amorosas só pode ser estabelecida quando a dimensão da perda é colocada para a criança, rompendo o liame gozoso estabelecido com a mãe nos primórdios da vida. O menino, cuja curiosidade é despertada pela excitação do pênis, passa a manipulá-lo, e por este ato recebe censuras por parte dos adultos, em alguns casos acompanhadas pela ameaça de retirada do órgão.

Às luz da revisão das convicções enunciadas em 1905, especificamente a ideia de que na fase primitiva do desenvolvimento infantil ainda não existia a primazia dos órgãos genitais, é preciso considerar que neste momento não existe organização das pulsões parciais em torno do órgão, à semelhança do que ocorre no adulto, mas é inegável o interesse que ele possui neste período da vida, como atesta a masturbação infantil. Freud (1923/1980) observa que a principal diferença entre esta primitiva organização e a do adulto reside no fato de que para os dois sexos só existe a referência do órgão masculino. "O que está presente, portanto, não é uma primazia dos órgãos genitais, mas uma primazia do falo" (p.180) e, por esta razão, ele pôde concluir, em um texto publicado no ano seguinte, que é a ameaça de castração que "ocasiona a destruição da organização genital fálica da criança" (Freud, 1924/1980, p.219).

É importante notar que existem outros fatores que concorrem para esta destruição, pois nem sempre o menino acredita imediatamente que pode sofrer algum dano em seu corpo. Freud (1924/1980) considera que a eficácia da ameaça 
de castração dependeria de uma preparação para a perda de partes valiosas do corpo, o que ocorreria em dois momentos: a retirada do seio materno e a exigência cotidiana de liberar as fezes. Não se pode afirmar, contudo, que estas experiências exerçam alguma influência no momento em que a criança escuta a ameaça de castração. A convicção de que isso pode realmente ocorrer só aparece quando o menino contempla a ausência do pênis na menina. A castração, neste sentido, precisa ser encontrada no outro, antes de ser experimentada como possibilidade concernente ao próprio ser.

Após tornar-se capaz de imaginar o que é a castração, a criança não se vê forçada a renunciar apenas à masturbação, mas também à satisfação obtida no complexo de Édipo, onde poderia obter uma satisfação ativa, por identificação ao pai, nas relações com a mãe, ou passiva, decorrente da identificação com a mãe, tornando-se objeto do amor paterno. A criança se convence de que deve abandonar esta modalidade de satisfação edipiana porque agora sabe que as mulheres também não estão livres da castração. Tanto a posição masculina quanto a feminina implicam a perda do pênis:

Se a satisfação do amor no campo do Complexo de Édipo deve custar à criança o pênis, está fadado a surgir um conflito entre seu interesse narcísico nessa parte de seu corpo e a catexia libidinal de seus objetos parentais. Neste conflito, triunfa normalmente a primeira dessas forças: o [eu] da criança volta as costas ao complexo de Édipo (Freud, 1924/1980, p.221).

A referência ao falo na consideração sobre a ameaça de castração se torna compreensível pelo fato de que a revelação do órgão feminino abala a soberania do órgão genital masculino na organização fálica. De acordo com Elia (1995), o impacto da diferença sexual no desenvolvimento libidinal é um problema que desde cedo mereceu a atenção de Freud em suas pesquisas. O encontro com o outro sexo introduz o sujeito masculino na experiência de algo que abala o universo das representações que sustentaram até então sua dinâmica libidinal. Em seu comentário sobre os textos freudianos dedicados ao tema, o referido autor salienta, a partir da perspectiva lacaniana, que o falo deve ser entendido como significante e não signo do pênis. Ele quer dizer que o falo não diz respeito a um objeto da realidade - neste caso, o órgão genital masculino mas a uma falta que a referência ao órgão anatômico não recobre. Como significante, portanto, o falo não tem correspondência com o objeto exterior, isto 
é, o pênis. É como "pênis faltoso" (na mulher) que o falo "introduz a dimensão simbólica da castração" (Elia, 1995, p.62).

O falo é comparável, devido ao seu estatuto de significante, ao fenômeno do Fort-Da, que deu a Freud o acesso à dialética entre presença e ausência: "A experiência do Fort-Da se refere à instalação da significação fálica, como inscrição primordial de um traço no inconsciente, marcando a perda de um gozo propriamente caracterizado pela presença do objeto" (Elia, 1995, p.64, grifo do autor). $\mathrm{O}$ falo como inscrição significante supõe a perda no campo imaginário, testemunhada com temor pelo menino ao contemplar o corpo da menina. 


\section{2 Angústia e defesa}

\section{1.} Angústia realística e angústia neurótica

Desde o início da teorização freudiana a angústia está associada à ideia de que algo não está acontecendo como deveria. Nas primeiras considerações sobre o tema era possível notar que o inadequado desempenho da atividade sexual estava na origem das crises de angústias. À medida que a teoria sobre a angústia progredia, tornou-se mais estreita a relação entre este afeto e a ocorrência de eventos capazes de perturbar o funcionamento do aparelho psíquico, exigindo uma reação que incida ao mesmo tempo no ambiente ameaçador e no psiquismo. Assim como as células tomam as outras como objetos, a fim de se unirem para prolongar suas vidas, o psiquismo também emprega a libido na construção do eu, que funciona como seu reservatório, dele se deslocando quando investe nos objetos.

A preocupação em situar o fenômeno da angústia em relação à dinâmica pulsional explicitada na teoria do narcisismo já podia ser observada alguns anos antes, numa das Conferências introdutórias dedicadas à angústia. Neste trabalho, Freud (1917b/1980) pretende mostrar o quanto a concepção psicanalítica da angústia se distancia da medicina, na qual é tratada como um fenômeno de ordem estritamente anatômica, tal como ele mesmo fez nos primórdios da psicanálise. A abordagem introduzida nesta conferência está apoiada em dois tipos de angústia, diferenciadas segundo a localização do fator que desencadeia o afeto: a "angústia realística" e a "angústia neurótica". A primeira caracteriza-se pela qualidade supostamente racional, pois nela é possível identificar facilmente que sua origem resulta da percepção de um "perigo externo", ou seja, algo que é previsível e, dependendo da situação, esperado. Este tipo de angústia está intimamente ligada ao reflexo de fuga "e pode ser visualizada como manifestação da pulsão de autopreservação" (Freud, 1917b/1980, p.459). 
Um aspecto que merece destaque é o fato de que o comportamento de fuga característico da "angústia realística" supõe o conhecimento dos objetos ameaçadores e das condições do meio. Esta condição contribui para que o aparecimento da angústia não seja experimentada com intensidade, pois aquilo que é conhecido não tem tanto poder de despertar angústia quanto o que é estranho ao nosso conhecimento. É por esta razão que um selvagem fica apreensivo quando vê um rastro na floresta, pois isto lhe indica a presença de um animal feroz. Em contrapartida, o mesmo rastro talvez não tenha nenhum significado para um habitante da cidade, alheio ao saber prático compartilhado no cotidiano da selva.

O caráter racional da angústia realística, no entanto, não pode ser sustentado se for considerado que, diante do perigo, a avaliação atenta e objetiva das condições de enfrentamento do perigo é cancelada pela presença da angústia. Se ela aparece, mesmo quando se conhece aquilo que ameaça, é porque a racionalidade está excluída. Embora o papel da pulsão de autopreservação apareça articulada ao emprego da angústia no estabelecimento de um estado de preparação para o perigo, ela deve ser mantida dentro de um certo limite: "Quanto mais a geração de angústia limitar-se a um início meramente frustrado - a um sinal -, tanto mais o estado de preparação para a angústia se transformará, sem distúrbio, em ação" (Freud, 1917b/1980, p.461). Se este limite é ultrapassado a angústia se impõe, tornando impossível qualquer ação, mesmo a de fuga. A angústia só se torna favorável à fuga quando o excesso pulsional é dominado e orientado à descarga motora.

Antes de avançar na análise da função defensiva da angústia, é imprescindível incluir neste estudo uma exposição sobre o que torna a angústia suscetível a esta finalidade. Ao explicar o que significa dizer que a angústia é um afeto, Freud (1917b/1980) observa que ela só pode ser usada como sinal com função defensiva quando é mitigada pelo eu. O que é interessante em sua descrição é a demonstração de que o afeto só pode fazer isto em função de sua composição, que inclui descargas motoras e sentimentos. Estes são compostos tanto pelas percepções de ações motoras quanto por sensações de prazer e desprazer. A importância desta descrição está no fato de que ela torna inteligível a hipótese de que todo afeto repete uma experiência significativa, o que só é possível se algum modo de registro for viável, gerando algum tipo de memória do 
evento, a partir das sensações e percepções. Por isso ele aproxima um estado afetivo do ataque histérico, concluindo que um afeto é resultado de reminiscências de um período primitivo da espécie. Um afeto repete, portanto, alguma impressão que não foi vivida pelo sujeito, mas herdada.

A preocupação em expor a concepção psicanalítica sobre os afetos serve para introduzir a ideia de que o afeto da angústia, com seus caminhos específicos de descarga, também repete uma experiência. As diversas situações de angústia experimentadas ao longo da vida estão relacionadas às modificações corporais provocadas no nascimento, em que se conjugam as descargas motoras e as sensações de desprazer "protótipo dos efeitos de um perigo mortal, e que desde então tem sido repetida por nós como o estado de angústia" (Freud 1917b/1980, p.462). O afeto repete a limitação da respiração e outras modificações fisiológicas geradas pelo parto, mantendo indissolúvel o vínculo entre estado de angústia e separação da mãe, da qual o afeto da angústia retira sua qualidade desprazerosa.

A partir deste aspecto é possível afirmar que a "angústia realística" parece ter sua manifestação direcionada ao aparecimento de algum tipo de ameaça real à vida, enquanto a "angústia neurótica" pode se apresentar de modos mais variados. A primeira manifestação deste tipo de angústia pode ser uma forma vaga, sem qualquer ideia específica a ela associada. Na verdade ela está sempre pronta para se vincular a qualquer ideia que sirva de explicação para a sua ocorrência. A presença de uma angústia livre gera a sensação de vulnerabilidade e iminente catástrofe subjetiva que justificam as interpretações pessimistas da realidade. Por outro lado, existe a angústia "psiquicamente ligada", ou seja, delimitada por objetos e situações específicas. É o que se observa, por exemplo, nas fobias, em que o perigo é localizável, ao contrário da "expectativa ansiosa" em que o perigo está em todos os lugares e, em última análise, em lugar nenhum, pois o sujeito não consegue determinar e eliminar a fonte de sua angústia. Há uma terceira forma de "angústia neurótica" em que não aparece qualquer associação com alguma espécie de perigo. Ela comparece associada a alguns sintomas, em situações nas quais não há, aparentemente, nenhuma razão para ficar angustiado. Também é possível que a pessoa tenha tremor, vertigem, palpitações, dispnéia, não havendo qualquer sensação subjetiva de angústia concomitante a estes sintomas. Apesar disso, Freud (1917b/1980) recomenda que estes estados sejam tratados como "equivalentes da angústia" e, por esta razão, correspondentes "à 
angústia para todos os fins clínicos e etiológicos" (p.467).

Foram as psiconeuroses, em particular a histeria, que forneceram exemplos de aparecimento da angústia junto com os sintomas e também em sua forma desvinculada. A análise da situação geradora de angústia revela que o afeto associado ao curso normal da atividade psíquica é "substituído por angústia, após a incidência do recalque" (Freud, 1917b1980, p.470). Uma angústia histérica, por este motivo, pode indicar a existência de vergonha inconsciente ou alguma excitação libidinal expressa como raiva: "Portanto, a angústia constitui moeda corrente e universal pela qual é ou pode ser trocado qualquer impulso, se o conteúdo ideativo vinculado a ele estiver sujeito a recalque” (p.470).

Deste modo, torna-se possível mostrar que, enquanto a "neurose de angústia" estava atrelada à região somática, a "angústia neurótica" é produto de um conflito psíquico. Esta constatação, no entanto, não auxilia no estabelecimento da diferença entre "angústia neurótica" e "realística", o que só pode ficar esclarecido quando se considera a relação entre a libido e o eu, na qual o recalque desempenha um papel fundamental, correspondendo, segundo Freud (1917b/1980), exatamente a "uma tentativa, feita pelo eu, de fugir da libido sentida como um perigo" (p.478), tal como faria diante de um perigo externo. É esta fuga da libido que caracteriza a "angústia neurótica". A angústia, então, surge como consequência do recalque, e o sintoma como tentativa de vincular a libido que ele liberou, impedindo sua descarga sob a forma de angústia.

A importância da libido na dinâmica da angústia fica ainda mais evidente quando se analisa o comportamento infantil. O susto da criança diante de uma pessoa estranha é frequentemente atribuído à presença de uma tendência à "angústia realística". O que se descobre em uma investigação atenta é que as crianças não temem o estranho por conhecerem suas intenções ameaçadoras ou por ter constatado a própria inferioridade diante dele. O temor da criança está fundamentado simplesmente no costume de sempre ter a mesma pessoa por perto, a quem ama muito: sua mãe. É a ausência da mãe que faz com que sua libido fique livre, sendo convertida em angústia. Não se trata apenas da ausência de uma pessoa, mas de alguém que serve como objeto de investimento libidinal, de cujas palavras e cuidados maternos a criança depende para conquistar sua estabilidade narcísica. O que é decisivo na manifestação da angústia em crianças não é seu caráter realístico, mas o fato de que se origina da libido não empregada: 
Enquanto encontrava-me no aposento ao lado, ouvi uma criança, com medo do escuro, dizer em voz alta: "Mas fala comigo, titia. Estou com medo!" "Por quê?" De que adianta isso? Tu nem estás me vendo". A isto a criança respondeu: "Se alguém fala, fica mais claro". Assim, um anelo sentido no escuro se transforma em medo do escuro (Freud, 1917b/1980, p.474, grifo do autor).

Há pouca angústia realística nas crianças, e por isso elas se aproximam frequentemente de situações de perigo, simplesmente porque os ignoram. É a tarefa de cuidar que aos poucos transmitirá à criança noções sobre o que ela pode fazer ou não, dando-lhe algum conhecimento sobre o que representa um perigo para a sua integridade. 


\section{2. \\ As neuroses traumáticas}

A teoria do narcisismo, bem como as primeiras elaborações sobre a angústia, revelam a centralidade da sexualidade na construção teórica da psicanálise, ainda que tenha havido o abandono da teoria do trauma sexual causado pela sedução do adulto. Os eventos da Primeira Guerra Mundial despertaram novo interesse pelo trauma, que ressurge sem a conotação sexual que lhe caracterizava até então. Foram as neuroses de guerra que impulsionaram o retorno deste tema nas pesquisas psicanalíticas. De acordo com Rudge (2009), os sintomas apresentados pelos soldados que retornavam dos campos de batalha levaram Freud a admitir que a neurose traumática não poderia ser equiparada à histeria. A consequência inevitável desta constatação apareceu no V Congresso Internacional de Psicanálise, realizado em Budapeste, onde ele expressou sua convicção de que a etiologia sexual não se aplica às neuroses de guerra e que estas, na verdade, são originadas por uma cisão do eu. As dificuldades encontradas para abordar as neuroses traumáticas com os recursos teóricos disponíveis naquele momento tiveram impacto decisivo sobre a teoria psicanalítica: "as reflexões que [a neurose traumática] gerou determinaram uma reformulação fundamental na teoria freudiana, a partir de 1920, envolvendo a formação do que se convencionou chamar de segunda tópica freudiana" (Rudge, 2009, p.43), na qual os conceitos elaborados até este momento receberam nova organização no conjunto da teoria.

Uma das principais modificações exigidas foi o abandono da primazia do princípio de prazer na economia do psiquismo, ocasionado pelo contato com os sonhos traumáticos, fenômenos que contrariam este princípio por repetirem justamente as situações de desprazer que caracterizam o evento traumático. A repetição destes sonhos obrigará Freud a considerar a possibilidade de que nem sempre o psiquismo busca encontrar o prazer e evitar o desprazer. Os sonhos traumáticos contrariam a concepção de que o sonho é uma realização de desejo, pois "tendem a reconduzir o sonhador exatamente à terrível situação que lhe causou intensa angústia” (Rudge, 2009, p.55). Ao invés de funcionar como tentativa de integração ao psiquismo de um acontecimento doloroso, motivada 
pelo princípio de prazer, a repetição dos sonhos traumáticos não se efetiva como simbolização do evento perturbador, permitindo que a angústia associada ao acontecimento retorne.

Um dos novos aspectos trazidos pelas neuroses traumáticas foi a ideia de que o Eu, neste caso, se defende de um perigo externo, o que representa uma grande diferença em relação às neuroses de transferência, em que o inimigo é interno. O inimigo externo pode ser qualquer evento que fuja ao controle da pessoa e lhe cause algum trauma físico ou psíquico, enquanto o inimigo interno é representado pela libido. $\mathrm{O}$ que tornou as neuroses traumáticas um assunto problemático para os psicanalistas na época foi justamente a inexistência daquilo que sempre foi tomado como a origem dos sintomas neuróticos: o conflito entre o eu e as pulsões sexuais. A ausência deste elemento na configuração das neuroses traumáticas serviu de arsenal para os críticos da psicanálise, que interpretaram este fato como a prova de que a sexualidade não é um fator etiológico importante para as neuroses.

Freud (1919a/1980) responde a tal investida argumentando que não se pode deduzir que a teoria sexual é incorreta do simples fato de que as neuroses causadas pela guerra não a corroboram. Ele acrescenta que se pode admitir a existência de um conflito no aparecimento das neuroses traumáticas, mas trata-se de um conflito no próprio eu, estabelecido entre um velho eu pacífico do soldado, e o eu moldado pelas circunstâncias da guerra, o bélico. Ele observa que o acirramento deste conflito ocorre quando o "eu pacífico compreende que perigo corre ele de perder a vida devido à temeridade do seu recém-formado e parasítico duplo" (p.261). A neurose traumática, nestes casos, também conhecidos como "neuroses de guerra", funciona como um refúgio para o velho eu, que se sente ameaçado pelo eu bélico.

Esta descrição se aplica a um modo particular de manifestação de neurose traumática, que também pode ocorrer em tempos de paz, em virtude de experiências assustadoras ou acidentes graves, não havendo, nestas situações, nenhum conflito alojado no eu. Contudo, nem mesmo nas neuroses traumáticas ocorridas em tempos de paz foi possível aplicar a teoria sexual da etiologia das neuroses, isto é, a teoria da libido.

Não foi a primeira vez que se encontrou dificuldades como esta. A demência precoce, a paranoia e a melancolia já haviam colocado em questão a 
teoria da libido. Seu emprego na descrição destas patologias - as neuroses narcísicas - só foi possível após o postulado da existência de uma libido narcísica, isto é, aquela que investe sexualmente o eu e se satisfaz no eu. Neste momento Freud (1919a/1980) faz um interessante voto acerca dos ganhos teóricos que esta nova perspectiva sobre a sexualidade pode proporcionar: "as neuroses traumáticas de paz ajustar-se-ão também ao esquema, assim que se alcance um resultado positivo nas investigações que fazemos das relações que, sem dúvida, existem entre o medo, a angústia e a libido narcísica" (p.262). O modo pelo qual o Eu reage às ameaças impostas à sua integridade aparece, ao final do texto, como um programa de investigação que permite aproximar as consequências da teoria do narcisismo e a teorização sobre a angústia.

O início da segunda seção do texto Além do princípio do prazer parece corroborar esta suposição. Ali se encontra um comentário sobre a concepção da neurose traumática como algo resultante de eventos que oferecem alguma ameaça à vida. Observa-se novamente a importância atribuída a guerra, não só como causadora de muitos casos de neurose traumática, mas também por ter indicado que esta não poderia ser considerada apenas como efeito de lesão do sistema nervoso provocada por alguma força mecânica. Freud (1920/1980) mostra-se satisfeito com este fato, embora reconheça que naquele momento não podia fornecer uma explicação completa para as neuroses geradas pela guerra, e tampouco pelas neuroses traumáticas observadas no tempo de paz.

No mesmo texto, mais especificamente na seção IV, aprece o esforço especulativo de Freud em torno da influência das relações com o meio sobre o desenvolvimento do organismo vivo. Freud (1920/1980) está convencido de que as pesquisas da embriologia podem lançar luz sobre os problemas encontrados na clínica psicanalítica. Ele propõe, então, que o organismo se desenvolve a partir de uma vesícula indiferenciada cuja superfície externa se diferenciará em função do recebimento dos estímulos do meio. Aos poucos esta vesícula desenvolve um tipo de proteção, sem a qual seria morta pelo excesso de estímulos. Neste sentido, ele advoga a favor da ideia de que a proteção contra os estímulos externos é mais importante do que a recepção deles, que na verdade serve apenas para informar a direção e o tipo de estímulos. Tal função é desempenhada, nos organismos desenvolvidos, pelos órgãos dos sentidos, responsáveis pela evitação de excessos de estímulos e exclusão dos que são impróprios. 
Uma abordagem metapsicológica desta dinâmica torna inevitável a consideração de que também existem estímulos internos com os quais o sistema Cs. precisa lidar. Este sistema, produto da evolução do escudo protetor da vesícula primitiva, encontra-se localizado entre o exterior e o interior. Quanto ao exterior, ele consegue êxito em manter o organismo protegido dos estímulos, mas contra os estímulos internos não há como pôr uma barreira. As sensações de prazer e desprazer suscitadas por eles se sobrepõem às estimulações externas. Uma solução para isto é tratar os estímulos internos como se fossem de fora "de maneira que seja possível colocar o escudo contra estímulos em operação, como meio de defesa contra elas" (Freud, 1920/1980, p.45). Assim se origina a projeção como mecanismo destinado a manter a estabilidade do funcionamento psíquico diante da insistência dos estímulos internos.

A descrição deste mecanismo, contudo, não esclarece os casos que escapam ao domínio do princípio de prazer, e por isso foi necessário retornar ao tema da neurose traumática. Neste momento ela é descrita como consequência de uma ruptura no escudo protetor, o que não significa a aceitação da teoria do choque como fator desencadeante. O texto é muito claro quanto à importância do susto e da ameaça à vida em detrimento da violência mecânica: "procuramos compreender $[\ldots]$ os efeitos produzidos sobre o órgão da mente pela ruptura do escudo contra estímulos e pelos problemas que se seguem em sua esteira. E atribuímos ainda importância ao elemento de susto. Ele é causado pela falta de qualquer preparação para a angústia" (Freud, 1920/1980, p.47), que consiste no investimento dos sistemas de recepção dos estímulos, preparando-os para vincular o excesso de excitação.

A função da angústia só ficará bem discriminada a partir da análise dos sonhos de pacientes que desenvolveram neurose traumática. Tais sonhos representam uma contradição ao princípio do prazer, pois, em vez de propiciarem uma realização de desejo, eles repetem a situação em que o trauma ocorreu. Os sonhos, neste caso, revelam outra função, que é a de restabelecer as condições necessárias ao funcionamento do princípio do prazer: "Estes sonhos esforçam-se por dominar retrospectivamente o estímulo, desenvolvendo a angústia cuja omissão constitui a causa da neurose traumática" (Freud, 1920/1980, p.48). Os sonhos de angústia revelam um funcionamento do psiquismo que, embora tenha relação com o princípio do prazer, mostra-se independente dele, desempenhando 
uma função mais fundamental do que a manutenção da homeostase, pois se orienta prioritariamente a contornar o trauma. $\mathrm{O}$ sonho repete o estado de angústia para dar ao aparelho psíquico a oportunidade de vincular o excesso de excitação provocado no momento do evento traumático. 


\section{3 \\ Da angústia à fobia}

\section{1.}

O caso clínico do pequeno Hans

A importância da noção de trauma para a investigação sobre o tema da angústia não se restringiu às primeiras proposições de Freud, mas adquiriu, ao longo do tempo, um novo lugar conceitual. Ela passou a ser representada pela castração, que, referida ao conflito edípico, surge na teoria psicanalítica como o trauma mais significativo da existência da criança (Rudge, 2009). O complexo de castração indica que o sujeito já convive com uma ameaça intrínseca a sua própria constituição. Este trauma é estruturante e anterior aos traumas contingenciais. Creio que as implicações clínicas deste fato podem ser apreendidas com muito proveito a partir do caso de fobia infantil consagrado sob o título "Pequeno Hans".

Para dimensionar a importância deste caso para a clínica da angústia é necessário estabelecer de modo preciso a constituição do objeto fóbico. Esta tarefa exige que se discrimine no quadro apresentado a existência de uma inibição (ir para a rua) e um sintoma (o medo de cavalos). É isto que se apreende de imediato. Uma análise cuidadosa do caso, no entanto, revela que o menino não experimentava um simples medo de cavalo; ele era mais específico quanto à apreensão deste objeto, indicando que o motivo de sua aflição era a possibilidade de ser mordido por ele. Este caso torna-se ainda mais interessante para o propósito desta pesquisa quando se constata que a doença de Hans teve início a partir de um sonho de angústia: "Hans (quatro anos e nove meses) despertou em lágrimas certa manhã. Quando lhe perguntaram por que estava chorando, ele disse a sua mãe: 'Quando eu estava dormindo, pensei que você tinha ido embora e eu ficava sem a mamãe para mimarmos juntos."' (Freud, 1909/1980, p.34).

No relato do caso o pai de Hans comenta que em diversos momentos surgiu a preocupação com o desaparecimento da mãe. Quando tinha que se afastar dela durante os passeios feitos com a babá, não demorava muito tempo para 
começar a chorar e suplicar o retorno à casa para "mimar" junto à sua mãe. Ao ser questionado sobre o motivo do choro, nada dizia. À medida em que a noite se aproximava, ele tornou a ficar assustado com a possibilidade de novamente ser afastado da mãe. Queria permanecer "mimando" com ela. No dia seguinte a este episódio, a própria mãe resolve levá-lo ao passeio a fim de descobrir o que estava amedrontando seu filho. Sua presença, no entanto, não impediu que ele ficasse assustado. Ao voltar do passeio, confessou à sua mãe, após muito esforço: "Eu estava com medo de que um cavalo me mordesse" (Freud, 1909/1980, p.35). Após ser acalmado, demonstrou temor pelo passeio do dia seguinte e afirmou: "O cavalo vai entrar no quarto" (Freud, 1909/1980, p.35).

Um guia importante para a compreensão do caso e sua relação com a angústia é o crescimento da afeição pela mãe. Isso explica porque Hans ficava tão perturbado ao cair da noite, quando se tornava mais próximo o momento de ir para a cama com ela, o que resultava no surgimento da angústia a partir da intensidade da libido não descarregada. Não era exatamente a existência de algo na rua que o incomodava, mas sim a angústia que o invadia. Freud (1909/1980) chama a atenção para o fato de que, embora a angústia tenha se originado do recalque de um intenso anseio relacionado à mãe, a presença dela no passeio do dia seguinte não foi suficiente para tranquilizá-lo: "O anseio pode transformar-se completamente em satisfação, se o objeto ansiado the for concedido [...] [A angústia] permanece até mesmo quando o anseio pode ser satisfeito" (p.37). Esta condição resulta da manutenção de uma parcela da libido sob a incidência do recalque, talvez porque a rua não é o ambiente adequado para ele "mimar" de maneira satisfatória com sua mãe. Foi este resto de angústia que estimulou a busca de um objeto capaz de evitar o seu aparecimento, o que ficou expresso na revelação do medo de que um cavalo o mordesse, feita quando retornou do passeio.

Um dos aspectos mais importantes no caso Hans é a expressão de sua sexualidade na forma de um interesse muito forte pelo seu órgão sexual, denominado "pipi", adotado também como referência para a distinção entre objetos animados e inanimados. Assim, ele podia afirmar que objetos como mesa e cadeira não têm "pipi", enquanto cachorro e gato o possuem. Seu uso também foi útil na percepção da diferença entre os sexos. É claro que o mesmo raciocínio foi estendido ao seres humanos, especificamente aos seus pais, percebidos como 
animais maiores. Partindo da comparação com os animais, logo inferiu que, se o tamanho do "pipi" é proporcional ao tamanho do animal, então ele provavelmente acompanharia o seu crescimento, o que resultou na conclusão de que seus pais deveriam ter "pipis" maiores que o seu.

Em algum momento a curiosidade de Hans o levou a explorar seu próprio “pipi” por meio do toque, resultando na descoberta do prazer sexual. O hábito de se masturbar já podia ser observado quando ele tinha apenas três anos e meio. Foi num dos momentos em que manipulava seu órgão que ouviu de sua mãe a ameaça que teve grande papel no estabelecimento da angústia e, consequentemente, da fobia: "Se fizer isso de novo, vou chamar o Dr. A. para cortar fora seu pipi" (Freud, 1909/1980, p.17).

O recalque desta ameaça certamente contribuiu para que, em seu desenvolvimento sexual, o prazer genital tenha se tornado o mais destacado. É importante lembrar que o prazer excretório também está presente, tanto na forma da micção quanto na da evacuação, o que ficou explícito na resposta que ele apresenta à sua mãe quando esta pergunta como fará pipi quando o órgão for cortado. Ele simplesmente responde: "Com meu traseiro" (Freud, 1909/1980, p.17). A resposta imediata de Hans não significa que ele tenha ficado ileso à intervenção materna, o que é claramente indicado por Freud quando comenta que este é o momento em que o complexo de castração é instaurado.

Numa nota acrescentada a este texto, em 1923, observa que a demonstração de que a privação do seio é sentida como uma castração (perda de uma parte importante do corpo) não deve excluir a importância da perda das fezes e do nascimento, em que a criança é separada do corpo da mãe. Dado o alcance do termo "castração", ele recomenda que o uso do termo "complexo de castração" fique reservado apenas aos casos em que está em jogo a perda do pênis. Uma das indicações de que a ameaça de castração produziu seu efeito é o fato de que houve recalque do impulso sexual relacionado ao ato de urinar e evacuar no período em que a fobia estava presente. Ele evitava urinar diante dos outros, não mais tocava em seu "pipi" e sentia nojo diante das fezes e também do "pipi".

Apesar da interferência de sua mãe, Hans continuou alimentando por ela uma enorme afeição. Logo foi possível constatar que o interesse por ela também se manifestava na forma do desejo de se livrar do pai, pois havia percebido que sua ausência resultava em maior proximidade da mãe: 
Nessa época a forma tomada pelo desejo tinha sido simplesmente que seu pai devia 'ir embora'; num estádio posterior tornou-se possível para seu medo de ser mordido por um cavalo branco ligar-se diretamente a essa forma do desejo [...] subsequentemente (provavelmente só depois que eles se tinham mudado para Viena, onde não devia mais contar com as ausências de seu pai), o desejo tomou a forma de que seu pai devia ficar permanentemente longe - que ele devia estar 'morto' (Freud, 1909/1980, p.119, grifo do autor).

Diante da peculiaridade do caso, Freud (1909/1980) encontra dificuldade para classificá-lo em alguma das categorias de neurose existentes. Admite que as fobias podem ser tomadas como síndromes cujas características estariam presentes em todas as manifestações neuróticas. Mas ele não consegue evitar a indicação de uma afinidade entre as fobias e as histerias, razão pela qual julga adequado referir-se ao tipo de fobia exibido pelo pequeno Hans como uma manifestação de "histeria de angústia". Sua proposta está fundamentada na constatação de que o comportamento da libido na fobia e na histeria é semelhante, exceto quanto ao que acontece quando ela é liberada da representação pela incidência do recalque: na histeria de angústia a libido não sofre conversão, mas é liberada na forma de angústia.

É por esta razão que a fobia se torna o desfecho mais comum das histerias de angústia, pois o psiquismo não consegue desfazer a transformação da libido em angústia, nem recuperar os complexos que estavam associados à libido da qual a angústia provém: "Nada lhe resta, a não ser cortar o acesso a todo possível motivo que possa levar ao desenvolvimento de [angústia], erigindo barreiras mentais da natureza de precauções, inibições ou proibições" (Freud, 1909/1980, p.124). O que a história de Hans permite concluir é que este conjunto de limitações não se referem apenas à liberdade de ir e vir, mas que ele é constituído fundamentalmente pelas restrições colocadas diante do seu desejo de estar com a mãe e de se livrar do pai.

Partindo do princípio de que um sonho é indicativo de um desejo recalcado, Freud (1909/1980) exclui a possibilidade de que o sonho de Hans tenha surgido como tentativa de usar uma possível angústia somática com o propósito de realizar um desejo. Ele propõe que o que se produz é uma punição por ter sonhado que estava tendo prazer por receber carícias de sua mãe. O que parece apoiar esta explicação é o fato de que, ao ser perguntado sobre o estado de angústia apresentado ao despertar, Hans diz que enquanto estava dormindo achou 
que a mãe ia embora, e por isso perderia os mimos que ela the concedia. Se ele sofre com a possibilidade da perda é porque de alguma maneira também experimentava, durante o sono, o prazer de sua presença. Neste caso o recalque interferiu no curso do sonho, transformando o conteúdo ideativo no seu contrário e convertendo o prazer em angústia.

O caráter fortemente sexual da relação com a mãe já havia surgido antes mesmo da primeira crise de angústia. Aos quatro anos, enquanto sua mãe secava seu corpo após o banho, evitando tocar o pênis durante a aplicação do talco, Hans estranha o cuidado demonstrado em relação a esta parte do corpo e pergunta:

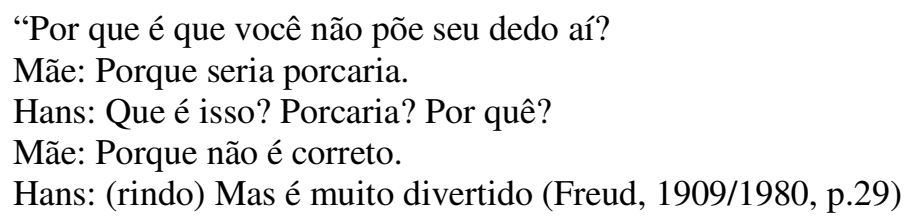

Nesta passagem, ao dizer francamente que era muito divertido colocar o dedo no pênis, ele parece ignorar o desprezo da mãe à sua tentativa de seduzi-la, mantendo seu pênis como fonte de diversão. A utilização do "cavalo" como substituto da mãe - em um primeiro momento - indica o quanto a identificação de Hans está articulada ao desejo de estar com ela mediante o atributo fálico. Hans estabeleceu que se o tamanho dos "pipis" dos animais é proporcional à dimensão do corpo, então sua mãe, que é um animal grande, deveria ter um "pipi" comparável a de um cavalo: "O cavalo tem o pipi embaixo, como eu" (Freud, 1909/1980, p.24). Ele é capaz de perceber que o do cavalo é maior e, portanto, há uma diferença entre os dois. Mas Freud (1909/1980) pondera que o medo do cavalo não está fundamentado no tamanho do órgão, pois em diversos momentos ele sentiu alegria ao contemplá-los e até mesmo desejou estar em lugares onde pudesse observá-los. Contudo, a sucessiva constatação de que o seu era menor contribuiu para a produção de uma aflição que também se transformou em angústia.

A proximidade do cavalo corresponde à proximidade do prazer que Hans extrai do seu pênis, que inevitavelmente se associou ao que ele experimentava no contato com sua mãe. É isto que fica sugerido no relato de uma história feito pelo próprio Hans: 
Quando Lizzi tinha de ir embora, havia uma carroça com um cavalo branco em frente da casa dela, para levar a bagagem para a estação [...] O pai dela estava parado perto do cavalo, e o cavalo virou a cabeça (para tocá-lo), e ele disse para Lizzi: "Não estenda seu dedo para o cavalo branco senão ele te morde". Nisso falei: Sabe, parece-me que você não quer dizer um cavalo, mas um pipi, onde ninguém deve pôr a mão (Freud, 1909/1980, p.40).

É importante indicar que no momento da primeira crise, durante um passeio pela rua, não havia manifestação de medo, mas apenas angústia. É o sonho que apresenta o medo de que um cavalo possa mordê-lo, tornando real a possibilidade de perder uma parte tão importante de si. Neste momento o pai de Hans já havia sugerido a ele que sua inibição de ir para a rua era causada pela atividade masturbatória. Ele foi aconselhado por Freud a esclarecer ao menino que suas dificuldades com cavalos eram apenas um modo de conseguir estar sempre próximo da mãe. O medo de cavalo seria resultante do interesse pelos "pipis" deles, tendo surgido à medida em que tomava consciência de que não era aceitável tamanha preocupação com este assunto. Mas este esclarecimento não foi suficiente, pois Hans continuava interessado em ver os cavalos, apesar do medo que sentia. Também não foi útil esclarecer que meninas não tinham "pipi”, pois ele permaneceu convicto de que sua mãe possuía um, o que foi revelado pela produção da fantasia de que a mãe o deixou ver o "pipi" dela. Seu desejo continuava fortemente dirigido à mãe, embora suspeitasse de que não era permitido se entregar livremente a ele.

Embora houvesse fortes indícios do papel que a afeição de Hans pela mãe desempenhava na produção dos sintomas apresentados, eram poucas as conexões entre a influência dela e o medo de cavalos. O significado do cavalo só foi compreendido quando Hans e seu pai foram atendidos juntos por Freud (1909/1980), que pôde constatar semelhanças entre a aparência do pai e as características dos cavalos descritos por Hans. Os óculos e o "preto em torno da boca", por exemplo, eram elementos que permitiram concluir que na verdade o medo dos cavalos era causado por sentimentos hostis do menino em relação ao pai, cuja presença representava um limite imposto ao convívio com sua mãe. Esta descoberta permite compreender que, ao afirmar, no sonho de angústia, que o “cavalo vai entrar no quarto", ele deu expressão ao medo de que o pai o impeça de possuir a mãe. A hostilidade contra o pai, motivada pelo ciúme, é transformada em medo de cavalo. 
$\mathrm{O}$ que desencadeou a fobia foi justamente quando o menino presenciou a queda de um cavalo. Provavelmente esta cena despertou em Hans o desejo inconsciente de que o seu pai morresse. Note-se que o cuidado de Freud em mostrar que a angústia se distingue do medo está bem fundamentada no fato de que no começo a angústia não estava referida a nenhum tipo de cavalo. A análise do caso revelou que no começo este animal estava muito associado ao prazer, pois o pai de Hans, em algumas brincadeiras, fingia ser um cavalo. A mudança na relação com este animal teve início com o medo de que pudessem cair, que estava associada à queda do seu amigo, Fritzl, ocorrida após bater o pé numa pedra. Hans evoca esta cena, e faz uma substituição de Fritzl por seu pai, ao explicar porque fugiu para casa ao ver dois cavalos puxando tranquilamente uma carruagem. Da mesma forma que Fritzl feriu o seu pé e caiu, Hans esperava que seu pai também batesse numa pedra e caísse, deixando-o mais à vontade para ir ao encontro de sua mãe. Não havia dúvida, no final do tratamento, de que a restrição de movimentos imposta pela fobia foi provocada a partir de ações onde Hans experimentava muito prazer, o que mais uma vez coloca em destaque o aspecto sexual na fenomenologia da angústia:

O conteúdo de sua fobia era tal que impunha uma grande medida de restrição sobre sua liberdade de movimento, e este era o seu propósito. Tratava-se, portanto, de uma poderosa reação contra os impulsos obscuros ao movimento que eram especialmente dirigidos contra sua mãe. Pois os cavalos de Hans sempre foram típicos do prazer no movimento ('Eu sou um jovem cavalo', disse ele enquanto pulava); mas já que esse prazer no movimento incluía o impulso para copular, a neurose impôs uma restrição a este e exaltou o cavalo como emblema de terror (Freud, 1909/1980, p.144).

A fobia deu um significado às ameaças associadas ao descobrimento de seu próprio corpo, deslocando para o exterior um perigo que é interior - a pulsão -, e que insiste em levá-lo em direção à sua mãe, objeto cada vez mais difícil de se apoderar, à medida em que ele cresce e que o pai se torna mais próximo. 


\section{2. O falo e o objeto fóbico}

Não se pode introduzir a importância do objeto fóbico neste estudo sobre a angústia sem adotar como referência outro tipo de objeto que tem importância inestimável na edificação da teoria analítica: o falo. Lacan (1995) afirma que este objeto é imaginário, e não pode ser confundido com o pênis enquanto órgão anatômico. A partir desta compreensão, não se pode mais supor que a criança mantém com sua mãe uma relação dual, pois a mulher, que não tem o falo, tentará extrair da criança uma satisfação capaz de escamotear sua privação. A relação entre eles, portanto, é ternária, pois o falo intervém como mediador na relação dos dois.

Isto fica expresso nas provocações que Hans dirige à sua mãe a respeito do "pipi”, significante empregado para se referir ao pênis. Ele se esforça em diversas situações para tentar estabelecer a equiparação entre este objeto de valor absoluto, o falo, e aquilo que ele observa à sua volta, sobretudo nos animais, em que tudo fica à mostra, o que estimula a curiosidade sobre a existência ou não dele em sua mãe.

A vida do menino permanece bem ajustada em torno do falo até o momento em que ele experimenta a excitação do pênis, resultando na prática da masturbação como forma de eliminá-la. Lacan (1995) considera que o aspecto decisivo a respeito do caso Hans não é a ameaça de castração que a mãe dirige ao menino para reprimir sua masturbação, mas sim a angústia que ele experimenta quando a excitação irrompe em seu corpo como algo até então desconhecido. Se antes ele era capaz de estabelecer correspondências entre seu "pipi" e os dos animais maiores, certamente o pênis excitado colocou uma dificuldade para as relações em torno do falo. Ele logo percebe que aquela inquietante parte do corpo tem alguma relação com a aproximação da mãe. É a propósito desta situação que Lacan (1995) observa que "o objeto fóbico vem preencher sua função sobre o fundo da angústia" (p.211) surgida na relação com a mãe, da qual o pequeno Hans tem dificuldade de escapar. Antes havia o falo como única referência para Hans e seu mundo se estruturava segundo esta matriz, ou seja, era feito à "imagem e 
semelhança" do seu falo. A partir da modificação corporal Hans conhece algo mais do que o falo. É neste momento que a angústia surge, ou seja, quando

[...] o sujeito é, por menos sensivelmente que seja, descolado de sua existência, e onde ele se percebe como estando prestes a ser capturado por alguma coisa que vocês vão chamar, conforme o caso, de imagem do outro, tentação etc. Em suma, a angústia é correlativa do momento em que o sujeito está suspenso entre um tempo em que ele não sabe mais onde está, em direção a um tempo onde ele será alguma coisa na qual jamais poderá se reencontrar. É isso aí, a angústia. (Lacan, 1995, p.231).

Mas para compreender adequadamente o alcance da mudança provocada pela excitação do pênis, é necessário atentar para o sonho que Hans teve com Mariedl, uma de suas amigas, quando tinha três anos e nove meses:

... Hans fez seu primeiro relato de um sonho: 'Hoje, quando eu estava dormindo, pensei que estava em Gmunden com Mariedl'. Mariedl era a filha de treze anos de nosso senhorio e costumava brincar frequentemente com ele. Quando o pai de Hans contava o sonho a sua mãe, na presença dele, ele o corrigiu dizendo: 'Não foi com Mariedl, mas sim bem a sós com Mariedl'. (Freud, 1909/1980, p.22).

Lacan (1995) valoriza bastante este episódio aparentemente trivial. Ao analisar esta passagem ele se detém no absurdo presente na correção apresentada por Hans e mostra que, ao afirmar que estava sozinho com Mariedl, ele demonstra mais uma vez o campo do imaginário, desta vez manifesto em sua relação com a irmã que havia nascido três meses antes. É na perspectiva da rivalidade com a irmã que se pode concluir que, ao dizer que sonhou estar a sós com Mariedl, ele está simplesmente traduzindo seu desejo de ficar a sós, isto é, sem a presença da irmã. É surpreendente que a mãe, o supremo objeto de amor para Hans, de repente se torna substituível por uma amiguinha. Isto só é possível porque Hans já havia se deparado com o desconforto de não conseguir mais ficar sozinho com ela. A raiz desta impossibilidade é o fato de que Hans valia para a mãe apenas como substituto de algo que lhe falta. O seu drama começa precisamente quando ele percebe sua mãe "como marcada por esta falta fundamental, que ela mesma procura completar" (Lacan, 1995, p.247).

O acabamento desta nova condição, em que é lançado pelo nascimento da irmã, surge com a agitação do seu pênis. $O$ espaço entre ele e sua mãe não é mais o do repouso e tranquilidade, mas de uma inquietação que ele não é capaz de 
dominar, não só porque seu pênis o agita, mas também porque começa a se dar conta de que o desejo da mãe está voltado para algo além dele. A relação imaginária já não é capaz de assegurar a presença da mãe. Ela sempre pode voltar seus olhos para a irmã ou simplesmente ignorar os apelos do menino.

A criança se vê capturada no jogo que ela mesma estabeleceu com a mãe, sem saber o que fazer nesta nova situação. Isto se torna ainda mais difícil porque ela o tratava como um objeto indispensável, carregando-o para todos os lugares. Lacan (1995) expressa sua predileção pelo campo da linguagem ao propor que a criança é a metonímia do falo da mãe, que ela não tem. Mas isto não quer dizer que o interesse materno esteja voltado para o falo do menino, o que fica evidente para pela recusa ao convite de tocar o pênis dele. Ela diz que não fará isto porque é uma porcaria (Freud, 1909/1980, p.29). O desprezo por seu pênis indica que o menino interessa à mãe não por causa daquela parte; é ele inteiro que representa o falo para ela.

Lacan (1995) ressalta que o fator determinante na investida pedagógica feita sobre o menino não é a rejeição manifesta pela mãe à sua dedicação amorosa, mas o fato de que ele, ao mesmo tempo em que percebe ser portador de algo que pode efetivamente ser apresentado à sua mãe, descobre que isto não é o que desperta o interesse dela: "Neste momento começa a se produzir aquilo a que se chama angústia, ligada ao seguinte: que ele pode avaliar toda a diferença que existe entre aquilo pelo qual ele é amado e o que ele pode dar" (p.249). O que o menino tem e considera precioso difere do que ela busca nele. A alegria e interesse do menino diante da manipulação do próprio pênis não são correspondidos pela mãe, que não só se recusa a tocá-lo, como também indica a ele que não deve continuar se masturbando. A recusa da mãe indica que o falo do menino não está incluído na imagem que ela faz dele. É no contexto desta inevitável divergência que a angústia emerge, como nos momentos em que Hans está longe da mãe e na companhia de outra pessoa, possibilidades que estão na origem de sua crise, ocorrida após um sonho no qual vivenciara a ameaça de que sua mãe fosse embora.

A fobia se instala quando Hans enfrenta estas transformações, e tem uma função a cumprir que deve ser bem delimitada. Um aspecto interessante da fobia é a dificuldade na representação de seus elementos. Um exemplo eloquente desta característica é a indefinição quanto ao cavalo que lhe causa medo. Embora a cor 
seja identificada como elemento relevante na determinação do objeto, Hans se detém numa mancha preta que ele não consegue identificar. É o pai quem deduz que talvez seja o arreio posto sob o nariz. Durante o interrogatório do pai, Hans descreve vários cavalos que lhe causam medo. Após começar a conversa dizendo que tinha medo de todos, ele aos poucos acrescenta outros tipos: os que têm a coisa preta na boca, os que puxam o ônibus e carroças (teme que estes caiam) e os que fazem barulhos com as patas. Apesar da quantidade de detalhes na descrição apresentada, pouco se revela sobre o que realmente assusta.

Na fobia, o que aparece ressaltada é a imprecisão do objeto. A angústia, por sua vez, diz respeito mais ao sujeito do que ao objeto. Ela "aparece quando a criança se sente, de súbito, como sendo ela própria algo que pode ser colocado completamente fora do jogo" (Lacan, 1995, p.251). Neste caso a indefinição não concerne ao objeto mas sim ao que a criança é para sua mãe. Mas há um ponto em que a fobia pode se comunicar com a angústia: a falta. Do mesmo modo que no objeto fóbico há algo que falta na descrição de Hans para torná-la objetiva e definitiva quanto ao que lhe causa medo, a criança também capta na mãe uma falta que a coloca num estado em que o seu próprio ser fica em suspenso. Lacan (1995) diz que isto ocorre por causa da descoberta de que na verdade ela é metonímia da mãe, padecendo do mesmo efeito que este recurso estilístico produz na literatura, ou seja, ele é arrastado em uma série de significantes que não culminam em um significado. A multiplicação dos detalhes serve apenas para indicar que eles visam a algo que não é abarcado pelos significantes. É a falta que faz a cadeia se propagar indefinidamente e é isto que confere à metonímia o poder de capturar aquele que está diante dela: "Nosso caro pequeno Hans se vê, então, de repente, precipitado nisso, ou pelo menos precipitável, por sua função de metonímia. Para dizer isso de forma mais viva que teórica, ele se imagina como um nada" (Lacan, 1995, p.252).

Ao declarar que os cavalos surgem da angústia, mas na verdade são portadores do medo, Lacan (1995) diferencia com precisão, assim como Freud, angústia e fobia. A construção de um objeto a ser temido é a maneira que Hans encontra de evitar a angústia, que não tem objeto ${ }^{3}$. Mas ao afirmar que os cavalos

3 Estou considerando a convicção freudiana de que a diferença entre o medo e a angústia é a existência de um objeto. A contribuição de Lacan sobre esta ideia será abordada em outro capítulo. 
surgem da angústia, ele indica que a criação do objeto fóbico não consegue eliminar totalmente este afeto, o que talvez explique a existência de um elemento impreciso que o relato do menino não consegue resolver. Os cavalos recobrem a angústia, e por isso o que Hans vivencia após a instalação da fobia é o medo dos cavalos, revelando que a eleição destes objetos é um modo de estabelecer pontos de referência em sua realidade fraturada. A fobia

introduz no mundo da criança uma estrutura, ela põe, precisamente, em primeiro plano, a função de um interior e de um exterior. Até então, a criança estava, em suma, no interior de sua mãe, e acaba de ser rejeitada dali, ou de se imaginar rejeitada, ela está na angústia e ei-la que, com ajuda da fobia, instaura uma nova ordem do interior e do exterior, uma série de limiares que se põem a estruturar o mundo. (Lacan, 1995, p.252-253).

A tese freudiana propõe a angústia como sinal de um perigo o que não diverge desta proposta feita por Lacan. Talvez a eficácia da fobia decorra do fato de que ela está, em sua constituição, articulada à angústia, e esta solidariedade se mantém mesmo depois de cumprida sua meta de estruturar o mundo do sujeito. Talvez seja este o sentido da frase: "a fobia é construída à frente do ponto de angústia" (Lacan, 1995, p.253). O que se revela preponderante neste processo é que o cavalo entra em cena como significante cuja função é construir limites que reorganizam o mundo de Hans e, ao mesmo tempo, inauguram a possibilidade de transgressão deles. $\mathrm{O}$ medo funciona como uma sentinela destinada a proteger de um perigo indefinido, pois a angústia é algo que não tem objeto determinado.

Há o medo, por exemplo, de que o pai vá embora, apesar do incômodo que este devia causar ao insistir em falar do pênis de Hans, sobre o qual este não tinha controle. Este medo nada mais é do que uma forma assumida pela angústia, que consiste fundamentalmente num "confronto do sujeito com a ausência do objeto onde ele é apanhado, onde se perde" (Lacan, 1995, p.353). O que Hans parece temer é a ausência do pai, atualizada em todas as intervenções nas quais ele fracassa em ser uma presença efetiva diante das convocações do filho para que assuma seu lugar no complexo de Édipo. A passagem mais esclarecedora do caso clínico sobre essa dificuldade é a que comparece no comentário de Freud após o relato feito pelo pai de Hans:

Hans: Quando não tiver mais medo não virei mais

Eu: Então você vem para junto de mim porque está assustado? 
Hans: Quando não estou com você eu fico assustado; quando não estou na cama junto com você, então fico assustado. Quando eu não estiver mais assustado eu não venho mais.

Eu: Então você gosta de mim e se sente aflito quando está na sua cama, de manhã? E por isso é que você vem para junto de mim?

Hans: Sim. Por que é que você me disse que eu gosto da mamãe e por isso é que fico com medo, quando eu gosto é de você?

Aqui o menino demonstrava um grau de clareza incomum. Ele chamava a atenção para o fato de que seu amor por seu pai entrava em conflito com sua hostilidade para com ele, considerando-o como um rival junto de sua mãe; e censurava seu pai por não haver ainda chamado sua atenção para esse jogo de forças (Freud, 1909/1980, p.54).

Por gostar da mãe ele sente angústia diante do que seu pai pode fazer com ele por causa do seu desejo de que o pai desapareça. Ao mesmo tempo revela que ama o pai, e por isso quer ficar junto dele, pois fica angustiado diante da possibilidade de que ele desapareça. Embora o pai de Hans jamais tenha feito tal ameaça, ele já sabia que isso era possível porque a mãe, em algum momento, diante de uma de suas travessuras, disse que iria embora. A angústia sentida em virtude do lugar vazio representado pelo pai tem como resposta a fobia, onde a angústia é transposta para a figura do cavalo.

Eu: Logo, você tem medo de que eu vá embora porque você foi travesso; por isso é que você vem pra junto de mim.

Quando levantei da mesa do café, Hans disse: 'Papai, não se afaste de mim nesse trote!' Fiquei abalado por dizer 'trote' em lugar de 'corrida', e respondi: 'Ah! Então você fica com medo do cavalo que se afasta de você, num trote.' Diante disso, ele riu. (Freud, 1909/1980, p.54).

A análise deste caso mostra a importância da temática do movimento. $\mathrm{O}$ medo que ele sente dos cavalos está fortemente associado ao modo como eles se movem, principalmente quando fazem isso com rapidez. Lacan (1995) considera que a angústia incide aí, quando alguém se sente arrastado por este movimento, mas também quando se fantasia a possibilidade de ser deixado para trás em uma queda. De fato, Hans não pode mais ser carregado com tanta estabilidade por sua mãe. A indicação de que o mundo não funciona como antes comparece na convicção de que os cavalos que puxam os ônibus vão cair. A angústia relativa ao movimento, embora tenha seus determinantes espalhados em todo o caso, é um dado que não pode ser superado porque decorre da estrutura simbólica do mundo, que arrasta o ser humano no movimento interminável característico da produção de sentido. 
Toda a construção de Lacan sobre este caso está orientada à ideia de que um objeto fóbico é sempre um significante. A presença do significante na constituição do cenário de ameaça no qual Hans está aprisionado fica mais evidente na dificuldade que ele sente de se afastar da sua casa a uma distância que lhe impeça de vê-la. Quando se mantém a uma pequena distância, consegue permanecer na rua mesmo que algumas carroças passem perto dele. Hans já havia feito uma associação entre a partida dos cavalos e o desejo de que seu pai fosse embora, e por isso ficava perturbado quando via uma das carroças da Agência da Alfândega - localizada próxima à sua residência - partir. $\mathrm{O}$ aspecto interessante no que diz respeito ao funcionamento do significante está na relação de Hans com sua casa - uma referência também importante na temática do estranho, que será abordado adiante. Lacan (1995) afirma que ele evitava se afastar de casa não tanto por ter medo de que seus pais tenham ido embora, mas que a casa vá para um lugar que ele não conhece. Não há duvida de que a casa está para Hans como um significante associado à mãe:

É a casa que está em causa, desde o momento em que ele compreende que esta mãe lhe pode faltar [...] O que ele teme não é tanto ser dela separado, e sim ser levado com ela sabe Deus para onde [..] na medida em que é solidário à mãe, ele não sabe mais onde está (p.336).

Existe a angústia de ser arrastado e cair, em relação à qual a queda do cavalo marcará sua presença mas também há o terror da ameaça de ser mordido por ele. A mordida seria a resposta da mãe à insatisfação em que foi lançada por não encontrar no filho o que desejava, e o terror causado no pequeno Hans por este perigo é acentuado pelo fato de que a mãe, por sofrer a privação, não pode ser mordida. A queda e a mordida do cavalo, em virtude da prevalência da função significante na estruturação da fobia, podem ser tomadas como duas faces da mesma moeda:

O cavalo morde, quer dizer: Já que não posso satisfazer a mãe em nada, ela vai se satisfazer como eu me satisfaço quando ela não me satisfaz em nada, isto é, vai me morder como eu a mordo, uma vez que este é o meu último recurso quando não estou certo do seu amor. O cavalo cai: ele cai exatamente como eu, pequeno Hans, fui deixado cair, na medida em que agora só se fala de Anna. (Lacan, 1995, p.568).

Tanto o nascimento de sua irmã quanto a agitação do seu pênis, rejeitado pela mãe, lançam-no, de fato, em uma queda da qual só pode se erguer se for 
capaz de restituir valor ao seu pênis. Por isso se torna necessária a mordida. Ela é uma forma de tirar o pênis da condição de algo desprezível, recolocando-o novamente no circuito do desejo materno. Deste modo a mordida aparece como algo ao mesmo tempo temido e desejado. A queda também tem este caráter de dupla face significante. A queda do cavalo é temida por Hans, mas também desejada, pois também está referida ao desejo de que sua irmã caísse da varanda.

O clima de ameaça se agrava porque Hans não é atendido em seu apelo para que o pai suprisse a insuficiência do falo que ele mesmo não pode mais contornar. Em última análise, o objeto fóbico tem como principal função compensar a ausência do pai castrador. Está claro que o simbólico é o que permite uma saída para o impasse estabelecido entre Hans e sua mãe, "fornecendo" um pênis ali onde ele não existe. É pelo simbólico que se coloca tanto a dimensão da ausência do pênis quanto a de sua recuperação. No caso de Hans o pênis é simbolicamente retirado de cena, por conta de todas as vicissitudes em que foi jogado por causa do prazer dele extraído, mas não é reinserido. O pai é a única referência em que ele pode depositar a esperança de receber um pênis digno. Aqui a relação se dá no plano imaginário, pois é um pai dotado do atributo de potência. Dar e receber não são metáforas, mas transformações operadas pelo simbólico. O cerne da castração encontra-se nesta oposição entre o pênis que funciona, o do pai, e o da criança, inválido. É isto que não é facultado a Hans, pois o pai em sua função imaginária não se impôs de modo a fazer sentir o perigo da castração:

Trata-se de saber como o pequeno Hans vai poder suportar seu pênis real, justamente na medida em que este não é ameaçado. Aí está o fundamento da angústia. O que há de intolerável em sua situação é essa carência do lado do castrador. (Lacan, 1995, p375).

Por isso Lacan (1995) afirma que a cura de Hans só pôde acontecer quando a castração é expressa na história do bombeiro que desatarraxa seu "pipi" e o substitui por um novo. Com esta história a criança emprega o simbólico para assumir a falta que atinge sua imagem, qual seja, a insuficiência do seu pênis. A relação com seu próprio corpo deve ser modificada para escapar do perigo em que ele se encontra. A ausência da presença castradora do pai é substituída pelo instalador. $\mathrm{O}$ abalo do mundo de Hans encontra-se inscrito no seu corpo sob a forma de uma alteração simbólica que atinge sua posição diante da mãe: "A 
revelação da castração dá fim à fobia, e mostra igualmente, não direi sua finalidade, mas aquilo que ela vem suprir" (p.236). 


\section{3. \\ Angústia, castração e desamparo}

Ao retomar este caso no período em que introduziu modificações em sua teoria da angústia, Freud (1926/1980) concedeu destaque à relação edipiana mantida pelo menino na época em que foi analisado. Foi identificada a presença de tendências ciumentas e hostis dirigidas ao pai, seu objeto de amor. O conflito decorrente desta ambivalência teria sido o estopim para a instalação da fobia como saída para o conflito. O objeto fóbico está relacionado ao recalque da hostilidade endereçada ao pai, o que foi comprovado pela associação entre a observação de um companheiro caindo do cavalo e o desejo de que seu pai sofresse uma queda e se ferisse. A análise do caso revelou que a agressividade contra o pai sofreu a vicissitude da inversão, tornando-se uma agressividade contra a criança, manifesta sob a forma do temor de vingança por ela ter se apaixonado pela mãe. Aliás, um dos efeitos produzidos pela fobia foi justamente o abandono do investimento libidinal em sua mãe, que, somado ao recalque da agressividade contra o pai, dissolve o complexo de Édipo. É importante ressaltar que havia também sentimentos afetuosos em relação ao pai, e provavelmente eles tiveram participação importante no afastamento da agressividade. Contudo, isto não é o suficiente para explicar o recalque, o que já representava uma dificuldade para Freud na época em que o menino foi acompanhado. Neste momento da teoria, entretanto, ele é capaz de afirmar com segurança qual foi o fator decisivo para a incidência do recalque:

Era o temor de castração iminente. 'Little Hans' desistiu de sua agressividade para com o pai temendo ser castrado. O medo de que um cavalo o mordesse pode, sem nenhuma força de expressão, receber o pleno sentido do temor de que um cavalo arrancasse fora com os dentes seus órgãos genitais - o órgão que o distinguia de uma fêmea (Freud, 1926/1980, p.130).

O retorno do que havia sido recalcado exigiu a substituição do medo de que o pai cometesse a castração pelo temor da mordida. Mas, antes de prosseguir, é preciso salientar um aspecto crucial para o tema deste trabalho, ou seja, a relação entre a incidência do recalque e a angústia. Freud (1926/1980) considera que a angústia vinculada à fobia não decorre da libido que ficou em estado livre após o recalque. A angústia gerada pela iminência da castração é que está na 
origem da intervenção do recalque como forma de evitar um perigo julgado como real. Torna-se impossível, a partir da clínica da fobia, sustentar que a angústia surge da transformação direta da libido. É a possibilidade de castração do eu que origina a angústia. É a libido, em última análise, o perigo que assola o eu, pois é por causa da satisfação (proibida) visada por ela que a ameaça de castração surge no horizonte.

Percebe-se que a castração funciona como um fator decisivo na distribuição da libido. A angústia de castração é deslocada para um objeto diferente, escolhido pelo fato de poder ser evitado mais facilmente. Contudo, a substituição de um perigo estritamente pulsional por um perigo localizável na realidade externa não pode ser interpretada como a prova de que a exigência pulsional é um perigo em si mesma. Ela só se torna perigosa efetivamente quando convoca um perigo real ao eu, ou seja, o perigo da castração. A fobia, neste sentido, permitiu comprovar que a angústia, por ser passível de evitação, é apenas um sinal destinado a defender o eu. Por este motivo não é justificável a diferenciação entre a angústia diante da castração e a angústia diante de situações de perigo. Uma pessoa que sente agorafobia, por exemplo, talvez seja acometida por este sintoma como forma de restringir o acesso do eu a satisfação de desejos eróticos que poderiam se associar ao perigo da castração experimentado na infância:

\begin{abstract}
A conclusão a que chegamos, portanto, é esta. A angústia é uma reação a uma situação de perigo.[...] Pode-se dizer que se criam sintomas de modo a evitar a geração da angústia. Mas isso não atinge uma profundidade suficiente. Seria mais verdadeiro dizer que se criam sintomas a fim de evitar uma situação de perigo cuja presença foi assinalada pela geração de angústia. Nos casos que examinamos, o perigo em causa foi o de castração ou de algo remontável à castração (Freud, 1926/1980, p.152).
\end{abstract}

O problema da participação do fator sexual na etiologia das neuroses traumáticas é lembrado novamente neste texto. A referência ao mecanismo da fobia como projeção de um perigo interno parece justificar o cuidado de Freud em reiterar o fato de que não se pode aceitar que as neuroses traumáticas sejam simples efeitos da perturbação da pulsão de autoconservação, ou seja, apenas reação a um perigo de morte. Novamente é destacada a importância do narcisismo como conceito que estabeleceu o caráter libidinal da pulsão de autoconservação. O vínculo entre narcisismo e castração se faz presente quando Freud (1926/1980) 
afirma que parece improvável que uma neurose se estabeleça apenas pelo aparecimento de um perigo objetivo, como são aqueles encontrados no desencadeamento das neuroses traumáticas; e acrescenta:

Mas o inconsciente parece nada conter que pudesse dar qualquer conteúdo ao nosso conceito do aniquilamento da vida. A castração pode ser retratada com base na experiência diária das fezes que estão sendo separadas do corpo ou com base na perda do seio da mãe no desmame. Mas nada que se assemelhe à morte jamais pode ter sido experimentado; ou se tiver, como no desmaio, não deixou quaisquer vestígios observáveis atrás de si. Estou inclinado, portanto, a aderir ao ponto de vista de que o medo da morte deve ser considerado análogo ao medo da castração (p.153).

$\mathrm{O}$ eu estaria, nos casos em que o perigo real da morte parece determinante, reagindo à possibilidade de se descobrir abandonado pela proteção do supereu. É importante ressaltar que o valor da castração para a compreensão da estrutura da angústia permeia todos os quadros clínicos. Nas neuroses obsessivas também se verifica que o eu constitui os sintomas a fim de evitar um perigo. Neste caso, ao contrário da fobia, o perigo é interno. Freud (1926/1980) comenta que o eu tenta fugir da hostilidade que o supereu lhe dirige, a qual é “extensão do castigo de castração" (Freud, 1926/1980, p.151). Enquanto a figura paterna sofre a internalização que tem por resultado a formação do supereu, o medo da castração experimentado no complexo de Édipo se transforma em "angústia moral", que costuma ser velada graças ao cumprimento fiel das restrições que são impostas ao eu. O descumprimento destas determinações frequentemente resulta no aparecimento de sensações descritas como angústia.

A ideia de que o eu está advertido acerca da castração pelas experiências de perda de objeto permite afirmar que a angústia deve ser considerada não mais como sinal de perigo, mas, "visto que o perigo é tão amiúde o de castração", parece mais adequado considerá-la como reação a "uma perda, uma separação" (Freud, 1926/1980, p.154). Introduz-se, aqui, a proposta de tomar como paradigma desta concepção de angústia o nascimento, entendido como a primeira experiência de separação. Freud, no entanto, não demonstra satisfação com esta hipótese, pois entende que naquele momento a criança não é capaz de perceber a si mesma como objeto e, portanto, não pode ter a experiência de que se separa de algo. Mas isso não o faz recusar a correlação entre angústia e separação. Impõese, então, a tarefa de especificar a experiência de separação que está na origem da 
angústia, o que permitirá diferenciá-la de outros afetos associados à separação, como a dor e o luto.

Uma característica que o problema da castração coloca em evidência é a especificidade dos mecanismos de descarga constituintes da angústia. Estou me referindo ao corpo, onde se pode detectar facilmente as modificações que normalmente acompanham a angústia, tais como aquelas observadas nos órgãos respiratórios e coração. Os processos de descarga ativados no momento de angústia são componentes indispensáveis na descrição do fenômeno, juntamente com o desprazer e a percepção das descargas motoras. A ocorrência de atos de descarga e a percepção dos mesmos é o que permite diferenciar a angústia de outros afetos desprazerosos, tais como a dor e o luto, onde a reação motora não tem relevância. A angústia consiste, portanto, em um aumento de excitação, causador de desprazer, cujo alívio é obtido por um ato de descarga. Esta angústia, segundo Freud (1926/1980), seria uma reprodução de alguma condição originária de aumento de excitação em circunstâncias marcadas pelo desprazer.

Reagir simplesmente com o estado de angústia seria impróprio porque corresponderia a um perigo anterior (o nascimento), no qual tal estado era adequado, pois as inervações dos órgãos respiratórios eram necessários para garantir a sobrevivência do organismo. A manifestação de tal estado de angústia não teria nenhuma finalidade diante do perigo atual. Graças à incidência do recalque é possível empregar a angústia em favor da defesa. Um dos efeitos mais interessantes produzidos pelo recalque é a transformação em desprazer do prazer que estaria associado à determinada satisfação. Isto permite modificar o curso da moção pulsional que emerge do isso, a partir da produção de um "sinal de desprazer" capaz de convocar o princípio do prazer a se fazer presente de maneira mais vigorosa. De fato, é tarefa do eu, dadas as suas vinculações com o sistema perceptivo - indissociável da consciência - lidar tanto com as excitações vindas de fora quanto aquelas de dentro, conformando-as ao princípio do prazer. Só é possível compreender como aquele sinal se efetiva como um mecanismo a serviço do princípio do prazer quando se considera que "a defesa contra um processo interno importuno será plasmada sobre a defesa adotada contra um estímulo externo" (Freud, 1926/1980, p.113). O recalque, no que se refere aos processos internos, é o correspondente à fuga de um objeto perigoso. É possível perceber neste texto o amadurecimento de muitas ideias esboçadas ao longo dos trabalhos 
anteriores sobre a angústia. É notável que a metapsicologia da angústia obtém maior especificidade teórica e clínica em função da importância concedida ao eu em sua dinâmica:

$\mathrm{O}$ eu retira sua catexia (pré-consciente) do representante pulsional que deve ser recalcado e utiliza esta catexia para a finalidade de liberar o desprazer (angústia) [...] podemos apegar-nos com firmeza à ideia de que o eu é a sede real da angústia, e abandonar nosso ponto de vista anterior de que a energia catexial do impulso recalcado é automaticamente transformado em angústia (p.114)

A explicação em termos econômicos revela-se incompreensível sob o prisma desta nova abordagem, pois a ideia de que o desprazer é provocado pelo aumento de tensão não se ajusta a este mecanismo, no qual se produz diminuição da tensão a partir da retirada da catexia. Freud (1926/1980) introduz neste quadro uma contribuição muito significativa. Ele tenta ultrapassar a explicação estritamente econômica em favor de uma análise que considera a angústia não como algo criado a cada vez pela transformação da libido que se encontra em estado livre, mas como um afeto associado a traços mnêmicos produzidos em experiências traumáticas primitivas. $\mathrm{O}$ desprazer aparece numa situação de redução dos investimentos porque decorre do investimento em traços de experiências desprazerosas. A utilidade da angústia como auxiliar nas defesas do eu deriva do fato de que ela repete a condição experimentada numa situação de perigo passada, a saber, os momentos de separação da mãe.

Isto ficou ainda mais explícito no contexto da crítica dirigida à teoria, proposta por Rank, do "trauma do nascimento", na qual este tenta vincular as fobias infantis às impressões de natureza predominantemente visual causadas pelo nascimento. Ele acreditava que o retorno destas impressões seria responsável pela ativação de uma memória relacionada ao nascimento, capaz de produzir angústia. Esta explicação daria conta, por exemplo, da reação de medo exibida pelas crianças diante de animais que se escondem em buracos. Mas Freud (1926/1980) considera esta hipótese insustentável, pois a criança não teria atingido um grau de consciência exigido para o estabelecimento de uma analogia entre o nascimento e o movimento de entrar e sair do buraco. Ao analisar certas situações que parecem entrar em contradição com esta tese - como quando a criança está sozinha no escuro - percebe-se o limite da argumentação de Rank, pois, apesar de se 
encontrar em um ambiente com uma característica tão semelhante à da vida intrauterina, a criança experimenta angústia. A angústia infantil ante a escuridão, quando se encontra sozinha ou na presença de um estranho, demonstra que existe um fator cujo valor para a elucidação das condições de produção daquele afeto é inestimável: a falta de alguém que ela ama. "Separação" e "castração" são duas noções que se aproximam porque possuem um aspecto em comum: a perda de um objeto de grande importância. Esta constatação implica que a angústia não mais pode ser tomada como repetição da experiência do nascimento, mas sim de um estado em que a criança anseia pela presença da mãe, aquela que é capaz de satisfazer suas necessidades, proporcionando a redução da tensão causadora de angústia:

A situação, portanto, que ela considera como um 'perigo' e contra a qual deseja ser protegida é a de não satisfação [...] A situação de não satisfação na qual as quantidades de estímulo se elevam a um grau desagradável sem que lhes seja possível ser dominadas psiquicamente ou descarregadas deve, para a criança, ser análoga à experiência do nascer - deve ser uma repetição da situação de perigo (p.161).

Nesta passagem ele se refere a algo que não pode ser "dominado psiquicamente" e por isso é percebido como perigo, exigindo um movimento de evitação. Tal movimento foi analisado neste mesmo texto sob o ponto de vista da dinâmica do psiquismo, evidenciando que a angústia aparece no momento em que os investimentos libidinais são retirados do objeto perigoso, repetindo os traços mnêmicos produzidos nas experiências traumáticas primitivas. A angústia, aqui, não aparece mais em estado "bruto", mas como algo que sofre uma intervenção capaz de utilizá-la como "sinal" de que uma ameaça ao eu se aproxima.

É importante lembra que o grito é a primeira expressão de angústia da criança, pura descarga. Mas como a descarga de excitação no aparelho respiratório e na musculatura vocal propicia a imediata convocação da mãe, servindo adequadamente ao propósito de salvá-la do perigo em que se encontra, adquire logo o valor de uma demanda de presença. Representa um ganho considerável para a manutenção do equilíbrio do aparelho psíquico a descoberta de que um objeto externo pode livrá-la do estado de perturbação econômica, pois o perigo deixa de estar associado tão somente à modificação ao aumento da quantidade de energia não descarregada, tornado-se algo relacionado à condição que causou esta 
alteração, isto é, a perda de objeto. Deste modo, a angústia deixa de ocorrer de modo automático para ser reproduzida com a finalidade de sinalizar um perigo: "nesses dois aspectos, como um fenômeno automático e um sinal de salvação, verifica-se que a [angústia] é um produto do desamparo mental da criança, o qual é um símile natural do seu desamparo biológico" (Freud, 1926/1980, p.162).

A importância da relação de objeto possui longo alcance na teoria e, sobretudo, na prática clínica, o que fica evidente pela importância que a perda de objeto adquire na evolução da obra freudiana como elemento determinante da angústia, aplicando-se também à angústia de castração. Nesta também está implicada a perda de um objeto, o pênis, cujo valor narcísico em grande parte decorre do fato de que ele é assumido como meio de obter, nas relações sexuais, o resgate da satisfação experimentada na união com a mãe. Ficar privado do pênis “equivale a uma renovada separação dela" (Freud, 1926/1980, p.163). Perder um objeto significa estar lançado novamente a um estado de tensão. A separação da mãe como correlata da perda do objeto é, em última análise, a experiência do próprio desamparo.

É nesta perspectiva que se conciliam as primeiras descobertas sobre a angústia com as mais recentes. A abstinência sexual ou a perturbação dos processos sexuais continuam valendo como demonstrações do fenômeno da angústia como derivado direto da excitação sexual somática. À luz da segunda tópica acrescenta-se a estas duas possibilidades a condição de desamparo a que o eu fica exposto, resultando na liberação da angústia, às vezes como sinal, e outras como angústia traumática.

O emprego da metapsicologia na investigação dos mecanismos de produção da angústia, aliada à experiência clínica, em particular a clínica da fobia, possibilitou a adoção de uma nova perspectiva acerca da função defensiva exercida pela angústia, o que permite localizar melhor sua importância para cada neurose:

Afirmei que no recalque o representante pulsional é distorcido, deslocado, e assim por diante, enquanto a libido que pertence ao impulso sexual é transformada em angústia. Mas agora um exame das fobias [...] deixa de sustentar minha asserção; parece, antes, contradizê-la diretamente. A angústia sentida em fobias a animais é o medo de castração do eu [...] É sempre a atitude de angústia do eu que é a coisa primária e que põe em movimento o recalque (Freud, 1926/1980, p.131). 
As conclusões de Freud sobre o perigo da castração na produção da angústia apontam para a participação da angústia de castração como causadora dos processos defensivos que produzem todas as formas de neurose, inclusive nas mulheres, em que a perda aparece como algo já estabelecido desde o início. Por esta razão, no caso das neuroses em mulheres, o que importa na determinação da angústia não é a perda do objeto, pois em virtude de sua constituição física isto não figura como possibilidade, mas como realidade efetivada. O que será determinante para a angústia na mulher é a perda do amor do objeto. 


\section{4 \\ O estranho: uma porta para a angústia}

\section{1. \\ O eu na relação especular}

Frequentemente o aparecimento da angústia na clínica é revestido de uma perturbadora obscuridade, responsável pela intensificação da perplexidade em que o sujeito já se encontra inserido em virtude do sofrimento gerado pelo sintoma que motivou o início do tratamento. Um dos aspectos que sobressaem nos relatos apresentados pelos analisandos é a dificuldade em localizar alguma causa para aquele afeto e até mesmo determinar o que ele é. É notável na experiência da angústia a impressão de que ela é um fenômeno que não se acomoda nas coordenadas sobre as quais o eu se orienta. Trata-se de algo que o sujeito não pode dizer o que é, pois parece ter uma origem desconhecida, mas, ao mesmo tempo, percebe que ela o concerne, pois é no próprio corpo que a experimenta. A imprecisão sentida na experiência da angústia não diz respeito, portanto, a uma dúvida quanto à existência do afeto. $\mathrm{O}$ sujeito tem certeza de que a angústia o invadiu. No entanto, as referências que usualmente asseguram a sua orientação no mundo parecem inúteis.

O percurso feito até este capítulo permitiu notar que a descrição da angústia, pelo menos sob a pena de Freud, esteve acompanhada de comentários sobre modificações corporais associadas ao surgimento deste afeto. Em outros momentos, foi destacado o aparecimento da angústia na relação com o outro, caracterizada como problemática tanto na esfera da copulação, quanto na da vida familiar e social, como ficou evidente no caso Hans e nos comentários de Freud sobre as neuroses traumáticas. A dispersão destes aspectos impôs a tarefa de tentar encontrar uma orientação mais precisa sobre a relação entre corpo, angústia e alteridade. Creio que a referência às considerações lacanianas sobre a constituição do eu no estádio do espelho, bem como os esquemas óticos apresentados em outros momentos de seu ensino, constituem contribuições 
inovadoras ao estudo da relação entre o corpo e a angústia, resultando no afastamento de uma descrição deste afeto em termos de mecanismos de descargas adquiridos na evolução da espécie para uma concepção que relaciona a manifestação da angústia com a ideia de um corpo unificado, descrito em seus aspectos imaginários e simbólicos.

Deve-se compreender, a princípio, que o estádio do espelho nada mais é do que um processo de identificação, isto é, uma transformação produzida quando o sujeito toma posse de sua imagem corporal. Este momento é antecedido por um intenso júbilo decorrente da passagem de um estado de impotência para uma condição em que a criança encontra na imagem especular uma forma. $\mathrm{O}$ surgimento da imagem cativante funciona como antecipação da maturidade corporal, ou seja, ela proporciona a percepção de totalidade, capaz de conferir ao corpo descoordenado alguma estabilidade e orientação que se traduzem na "permanência mental do [eu], ao mesmo tempo que prefigura sua destinação alienante" (Lacan, 1949/1998, p.98) no outro que reflete para ele sua imagem. A respeito desta relação entre imagem e corpo, Lacan usa como metáfora a maturação da gônada de pomba a partir da visão de outro membro da espécie, independentemente do sexo, efeito que pode ser obtido com a colocação de um espelho na frente dela. Ele ressalta que a função do estádio do espelho consiste precisamente em promover "uma relação do organismo com sua realidade" (Lacan, 1949/1998, p.100), que no ser humano é desde o início perturbada por um mal-estar que advém da condição prematura do nascimento, em comparação aos seres de outras espécies.

A precoce capacidade de reconhecer a forma humana permite à criança experimentar a captação pela imagem e o júbilo a ela associado, o que não se observa nos animais. Embora os chimpanzés, por exemplo, percebam sua imagem no espelho, não conseguem se relacionar a ela como objeto, expressando indiferença diante dela. Em outro texto, Lacan (1948/1998) descreve o estádio do espelho como "dinamismo afetivo pelo qual o sujeito se identifica primordialmente com a Gestalt visual de seu próprio corpo: ela é, em relação à descoordenação ainda muito profunda de sua própria motricidade, uma unidade ideal, uma imago salutar" (p.115) que vai influenciar todo o seu desenvolvimento. É o caráter preponderante desta imago, consequência da prematuração do filhote humano, que se observa na primeira infância no fenômeno do transitivismo, pelo 
qual a criança chora quando vê outra cair, ou quando, ao bater, diz que bateram nela. É nesta fixação alienante a uma imagem que se estrutura a tensão manifesta no desejo pelo objeto do desejo do outro, o que envolve o deslocamento de uma situação de alienação ao outro para uma relação marcada pela agressividade, da qual "nasce a tríade do outro, do eu e do objeto", responsável pela destruição da “comunhão especular”(p.116).

É a partir da relação com esta imagem, que é exterior ao corpo, mas ao mesmo tempo influente sobre seus movimentos, que provêm as relações entre o sujeito e as estátuas criadas para representá-lo ou qualquer outra forma similar à humana, como os autômatos, que prolongam a tarefa de fabricar a si mesmo. É nesta relação ambígua entre o sujeito e a imagem, que reenvia a si o seu corpo, que se localiza, por exemplo, a aparição do duplo, tema característico da experiência do estranho, que será abordado adiante.

Em outro momento de sua obra, Lacan (1986) incorpora os pressupostos do estádio do espelho em sua elaboração sobre a realidade psíquica, motivado pelo fato de que nem mesmo Freud propôs o psiquismo como estrutura redutível à organização anatômica. Ele comenta que o lugar psíquico é como uma imagem formada a partir de estímulos recebidos por meio da atividade perceptiva, e por isso compara o funcionamento do aparelho psíquico ao de um aparelho ótico.

O primeiro esquema ótico apresentado por ele neste trabalho é simples, composto de um espelho, um pequeno vaso e um ramo de flores colocado sob o vaso, fora do campo visual do observador. O reflexo dos raios formam um buquê imaginário situado no interior do vaso. O que deve ser retido deste esquema é que o vaso e a flor ilustram a relação de continente e conteúdo que caracteriza a dinâmica de formação do eu primitivo, constituído a partir de uma distinção entre interior e exterior, onde o que interessa à satisfação do organismo é incluído e o que não interessa é rejeitado, tornando-se parte do exterior.

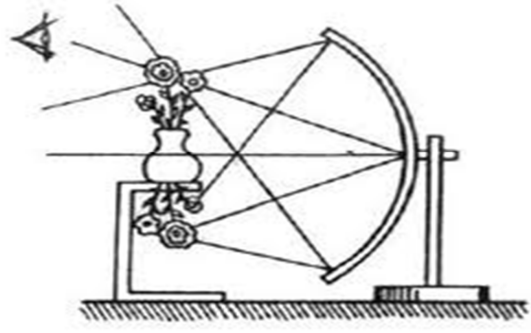

(Lacan, 1986, p.94) 
A eleição do que deve permanecer interno e, por conseguinte, do que ficará alojado no exterior, não indica a atividade de uma consciência plenamente desenvolvida. A conquista da coordenação das funções motoras é algo que ocorre apenas depois da maturação fisiológica, mas ela depende de uma apreensão imaginária do corpo que não se confunde com sua maturação: "É a aventura original através da qual, pela primeira vez, o homem passa pela experiência de que se vê, se reflete e se concebe como outro que não ele mesmo" (Lacan, 1986. p.96), pois percebe uma totalidade do corpo que na verdade ainda não possui.

É esta imagem do corpo que permitirá ao sujeito estabelecer o que pertence e o que não pertence ao eu, em meio ao caos original, onde não é possível definir os objetos. Neste esquema, a imagem do corpo é o vaso imaginário com o buquê em seu interior. É importante notar que a formação desta imagem, tal como está exibida no esquema acima, depende do posicionamento do observador em relação aos raios. Isto significa que a composição formada pelo imaginário e pelo real é definida pela situação do sujeito, ou seja, "pelo seu lugar no mundo simbólico, ou, em outros termos, no mundo da palavra" (Lacan, 1986, p.97). Em resumo: o real neste momento de sua obra corresponde ao caos original a partir do qual o sujeito constitui seu eu no plano imaginário segundo as coordenadas simbólicas em que foi introduzido nos primeiros momentos da vida.

No segundo esquema é o vaso que se encontra invertido. Ele vai aparecer, a partir do reflexo dos raios que partem do espelho côncavo, como imagem real. Dependendo da posição do observador, é possível perceber a imagem real do vaso envolvendo o buquê, dando-lhe "estilo e unidade - reflexo da unidade do corpo" (Lacan, 1986, p.146). A colocação de um espelho plano e o adequado posicionamento do observador permitirão que ele veja não só o seu reflexo no espelho, mas também o vaso, que vai aparecer numa posição simétrica à da imagem real como imagem virtual.

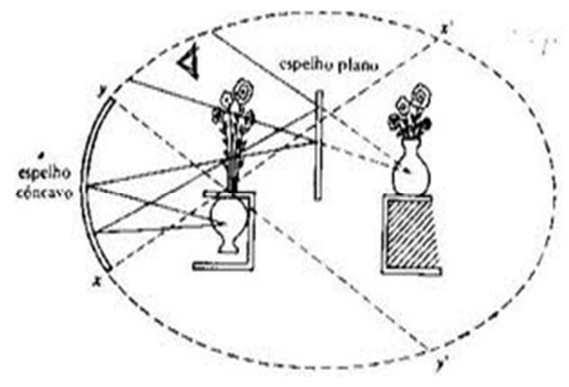


Lacan observa que num primeiro momento da constituição do eu o que existe é um narcisismo vinculado à imagem do corpo, que confere uma forma ao corpo e também ao seu mundo. Este narcisismo corresponde, no esquema, à imagem real, esta que serve de base para a construção de uma organização da realidade. Ao contrário dos animais, o ser humano não possui uma tendência que o adapta ao mundo de maneira uniforme. Ainda que os animais possuam uma estrutura imaginária, ela apenas subordina o mundo que os cerca à função de propagar a espécie. Quanto ao homem, "a reflexão no espelho manifesta uma possibilidade noética original, e introduz um segundo narcisismo. $\mathrm{O}$ seu pattern fundamental é imediatamente a relação com o outro" (Lacan, 1986, p.148). É a identificação ao outro, estabelecida no segundo narcisismo, que será determinante na orientação da relação imaginária do homem com o mundo. É isto que estrutura o seu ser: "O sujeito vê o seu ser numa reflexão em relação ao outro, isto é, em relação ao Ich-Ideal'. (Lacan, 1986, p.148).

O ideal do eu é aquilo que tem o poder de comandar o sujeito, isto é, determina sua posição na estrutura imaginária a partir do plano simbólico. É por isso que o ser humano não pode apreender sua forma senão fora de si, na relação com o outro, mas não do mesmo modo como ocorre nos animais, em que a aparência de cada espécie serve para deflagrar um comportamento sexual invariável. No ser humano não existe a coincidência entre o impulso sexual e um objeto. Não há, portanto, na constituição da imagem de si, a correspondência harmoniosa com o outro. $\mathrm{O}$ fato de precisar do outro para constituir sua imagem significa, na verdade, o quanto o ser humano é impotente. O instinto coloca o animal em vantagem, pois ele já tem algum saber que lhe coloca a caminho das ações necessárias à autoconservação. A estruturação do corpo humano e de todas as suas faculdades só poderá ter algum sucesso no campo da troca simbólica. Sem isso o imaginário não se organiza e também não adquire sua eficácia para a ação do desejo, pois o que é fundamental na formação da imagem é o investimento da libido, "aquilo através de que um objeto se torna desejável" (Lacan, 1986, p.165).

A conquista triunfante da própria imagem a partir do olhar do outro não é outra coisa senão a apreensão inicial de um desejo. Para o reconhecimento do desejo por parte do sujeito é imprescindível a relação entre a própria imagem e o 
corpo do outro. É isto que sustenta a experiência da consciência de si como algo separado do corpo, razão pela qual em algumas situações ele realmente não parece pertencer a nós. É pela referência ao desejo que se pode fazer um uso satisfatório dos esquemas óticos, tornando mais compreensível a importância e o lugar da relação imaginária na clínica:

$E u$ é um termo verbal, cujo uso é apreendido numa certa referência ao outro, que é uma referência falada. $\mathrm{O} e u$ nasce em referência ao $t u$. [...] numa relação em que o outro lhe manifesta o quê? - ordens, desejos, que ela deve reconhecer, do seu pai, da sua mãe, dos seus educadores, ou dos seus pares e camaradas (Lacan, 1986, p.193, grifo do autor).

A experiência da criança ao se deparar com a própria imagem permite discriminar tanto uma forma bem delineada, que aparece na imagem do espelho, quanto a falta de coordenação de seus gestos, que denunciam o estágio de inacabamento de suas funções corporais. Este descompasso entre a imagem e o corpo constitui o limite presente na constituição narcísica.

Neste cenário surgem duas possibilidades: tolerar o outro ou destruí-lo, eliminando, assim, a ameaça representada pela presença do semelhante. Contudo, a relação com o outro não é suficiente para que se obtenha a consistência da relação narcísica. É imprescindível que um terceiro, o grande Outro, participe. É este aspecto que ganha destaque na referência ao encontro da criança com a imagem no espelho. Se esta experiência fosse suficiente, não persistiria a instabilidade que decorre da própria oscilação entre o que é visto no espelho e o que a criança experimenta de seu corpo quando se afasta daquela imagem. Ela não tem recursos para assegurar a si mesma a correspondência daquela imagem ao seu corpo. O fascínio resultante da apropriação, pela criança, de sua imagem corporal, é possibilitado pela entrada do Outro, que estabelece uma dialética a partir da relação imaginária. A criança

volta-se para o adulto que a carrega, sem que se possa dizer sem dúvida o que espera disso, se é da ordem de um acordo ou de um testemunho, mas a referência ao Outro vem desempenhar aí uma função essencial". [Ela recebe] "o signo imagem de $a$, essa imagem especular, desejável e destruidora ao mesmo tempo [...] É isso que vem daquele para o qual o sujeito se volta, no próprio lugar onde ele se identifica nesse momento, na medida em que sustenta sua identificação com a imagem especular"(Lacan, 1992, p.342). 
Num primeiro momento o que a criança capta no outro é apenas a figura de um corpo, tomado como uma espécie de recipiente cujo uso ainda é desconhecido. É a visão deste corpo associado aos significantes recebidos, que aos poucos vai organizar a confusão em que se encontra a criança em relação ao seu desejo em vias de constituição, que neste momento se esboça como um grito ou choro. É o uso da linguagem que vai permitir a ultrapassagem da condição imaginária do desejo, em que este fica alienado no outro, razão pela qual, nesta fase, o desejo, para se afirmar, precisa destruir o outro. O que se verifica, então, a partir da incidência do simbólico, é a possibilidade de que o outro seja reconhecido como tal a partir de uma separação que permite ao desejo perdurar sem a necessidade de destruição do outro. Talvez este seja o sentido do termo incorporar: tornar própria, por meio do desejo, a imagem captada no outro, liberando-se deste mas ainda mantendo alguma relação com ele, razão pela qual se diz que o desejo é desejo do outro, pois nenhum desejo posterior escapa da referência ao campo da alteridade.

É nesta relação com algo exterior e ao mesmo tempo muito próximo que a temática do estranho se aproxima da experiência da angústia. 


\section{2. \\ A inquietante estranheza}

O texto dedicado ao fenômeno da estranheza desenvolve-se em torno do conto fantástico de Hoffmann, intitulado 'O homem de areia'. A importância de apresentar esta história se deve ao fato de que ela permite abordar a relação entre fantasia e angústia, antecipando, assim, algumas indicações importantes para o estudo de Lacan a respeito deste último tema. Uma delas, senão a principal, é a perturbação da relação entre o eu e o outro, que fica revestida de uma incerteza que pode atingir intensidade suficiente para gerar angústia.

O comentário freudiano sobre o conto começa pelas recordações de infância do personagem, um estudante chamado Nataniel, que, embora se sinta muito feliz no presente, não consegue se livrar das lembranças da morte de seu pai. Uma característica curiosa da conduta deste pai era o hábito de, em algumas noites, ocupar-se com um visitante cujos passos Nataniel não deixava de ouvir, e que associava às advertências da mãe sobre a chegada de um certo Homem da Areia caso não fossem para a cama na hora certa. O próprio Freud (1919b/1980) menciona que a mãe não acreditava na existência deste ser e apenas se referia a ele como "figura de linguagem", e que Nataniel não se importava com ele. O medo do Homem de Areia, no entanto, veio ao seu encontro pela descrição que a babá forneceu, conferindo àqueles significantes um efeito que a mãe não foi capaz de propiciar:

É um homem perverso que chega quando as crianças não vão para a cama, e joga punhados de areia nos olhos delas, de modo que estes saltam sangrando da cabeça. Ele coloca então os olhos num saco e os leva para a meia-lua, para alimentar os seus filhos. Eles estão acomodados lá em cima, no ninho, e seus bicos são curvos como bicos de coruja, e eles os usam para mordiscar os olhos dos meninos e meninas desobedientes (Freud, 1919b/1980, p.285).

Os olhos das crianças que se recusam a ir para a cama servem de alimento aos filhos do homem da areia. Chama a atenção que a parte do corpo ameaçada sejam os olhos, tão associados à busca do saber. A continuação do comentário parece apoiar esta observação, pois a caracterização apresentada pela babá funcionou como estímulo a uma irresistível curiosidade sobre a identidade do Homem de Areia. Nataniel queria, como se costuma dizer, ver para crer. 
Numa certa noite, quando seu pai esperava o misterioso visitante, Nataniel se escondeu no escritório. Descobriu que o visitante de seu pai era o advogado Copélio, conhecido pelo desagradável hábito de assustar as crianças quando ia jantar com sua família. As impressões causadas por estes encontros devem ter favorecido a identificação do repugnante Copélio com o Homem de Areia. É como se, para usar um pouco de metapsicologia freudiana, o representante "Homem de Areia" tivesse finalmente encontrado um afeto provocado pelos sustos produzidos por Copélio - capaz de lhe dar o poder de causar algum efeito subjetivo em Nataniel.

$\mathrm{O}$ aspecto que parece interessar a Freud como sendo fundamental ao sentimento de estranheza surge após a descoberta da identidade do visitante, quando se torna difícil discernir no relato o que é fantasia e o que é realidade. Ao ver o pai mexer em um braseiro com o seu convidado, Nataniel ouve Copélio dizer: "Aqui os olhos! Aqui os olhos". Ao escutar isto, solta um grito que revela sua presença na sala. Copélio reage, ameaçando jogar as brasas em seus olhos e depois colocá-los dentro do braseiro, sendo impedido pelo pai do menino. Freud (1919b/1980) reconhece como evidente a conexão entre este episódio e a descrição da babá sobre o Homem de Areia. A areia que deveria ser jogada nos olhos da criança desobediente dá lugar às brasas. Em ambos os casos o objetivo continua sendo atingir os olhos das crianças por causa da desobediência em relação a algo que deveria ter permanecido velado. Tanto a ordem de ir para a cama antes da chegada do "Homem de Areia" quanto o cuidado de Nataniel em se manter escondido no escritório atestam que a criança não deve ver quem vai chegar. O suspense em torno do advogado aumenta a partir do falecimento do pai do menino, morto por uma explosão ocorrida no escritório durante uma das visitas de Copélio, que abandonou o local sem deixar pistas.

Mais tarde, já como estudante, Nataniel suspeita ter reencontrado aquele personagem medonho na pessoa de um oculista chamado Coppola, que trabalhava na cidade universitária. Após comprar dele um telescópio - que na verdade era anunciado como "olhos" - pôs-se a observar uma residência próxima, pertencente ao professor Spalanzani. No interior da residência descobre a filha de Spalanzani, chamada Olímpia, cuja imobilidade e silêncio não foram obstáculos ao surgimento de uma paixão que imediatamente o fez esquecer de sua noiva. 
O jovem estudante logo descobre que Olímpia é um autômato construído com a ajuda de Coppola, ao qual caberia a tarefa de instalar seus olhos. Ao aparecer, no momento em que os dois estavam conversando sobre Olímpia, o oculista deixa o local levando consigo a boneca, sem os olhos. Em seguida, Spalanzani pega do chão os olhos de Olímpia e, acusando Coppola de tê-los roubado de Nataniel, joga-os sobre o peito deste. No mesmo instante o jovem é tomado pela loucura:

[...] no seu delírio, a recordação da morte do pai mistura-se a essa nova experiência. 'Apressa-te! Apressa-te! Anel de fogo!', grita ele. 'Gira, anel de fogo - Hurrah! Apressa-te, boneca de pau! Linda boneca de pau, gira - .' Cai então sobre o professor, o 'pai' de Olímpia, e tenta estrangulá-lo (Freud, 1919b/1980, p.287).

O caráter de incerteza relativo a alguns aspectos da história, como aquele relacionado à condição animada ou inanimada da boneca Olímpia, não é suficiente, na opinião de Freud (1919b/1980), para explicar o efeito de estranheza provocado no leitor. Ele supõe que tal efeito, na verdade, está ligado à figura do Homem de Areia e, de modo mais específico, à possibilidade de que ele arranque os olhos do jovem Nataniel. O que há de aterrador em toda a história é exatamente a certeza de que Coppola é o advogado Copélio, o que significa para Nataniel que o Homem de Areia pode realmente fazer o que a babá havia contado. Fica explícito o vínculo existente entre o aparecimento da angústia e o retorno da ameaça de castração - recalcada - que havia sido veiculada pela babá. Este aspecto torna-se ainda mais importante quando se constata que o medo de ter os olhos feridos ou perdidos é algo perturbador tanto para as crianças quanto para os adultos. A estima pelos olhos e sua relação com o desejo pode ser verificada, por exemplo, quando se ouve alguém dizer que dá importância a algo como se aquilo fosse a menina dos olhos.

Freud (1919b/1980) parte de sua experiência com a análise de sonhos e mitos para afirmar que a angústia experimentada em relação aos olhos "é muitas vezes um substituto do temor de ser castrado" (p.289). Quanto a este aspecto, a análise do caso Hans já havia proporcionado a Freud muitos indícios comprobatórios de sua teoria acerca da relação entre o olhar e o prazer sexual, razão pela qual nem tudo pode ser visto. Naquele caso clínico ficou evidente como a atividade do olhar, fonte de prazer devido ao vínculo com a contemplação 
do pênis na masturbação,pode se transformar em um perigo a ser evitado. A perda do interesse em observar os cavalos para satisfazer sua curiosidade sobre a diferença entre os sexos começou a partir da experiência da angústia relativa ao prazer sexual experimentado em seu pênis.

O aparecimento da angústia no conto também está relacionado com eventos perturbadores da vida sexual, os quais estão sempre relacionados à interferência do Homem de Areia nas relações amorosas de Nataniel: ele o separa da noiva, elimina Olímpia, e o leva a cometer suicídio diante de sua amada após avistar Copélio caminhando na rua. São estes fatos que fortalecem a convicção de Freud (1919b/1980) acerca da influência da angústia de castração na produção do sentimento de estranheza que o Homem de Areia causa.

Ao abordar este conto em seu estudo sobre a angústia, Lacan (2005) também valoriza a relação entre este afeto e a castração associada aos olhos. Ele considera que o olho possui a propriedade de favorecer o desconhecimento do desejante que existe no desejável. A partir desta ideia ele afirma que o aparecimento do estranho (unheimlich) corresponde à entrada do desejante no lugar do desejável, o que permite supor que o colapso de Nataniel não foi produzido pela descoberta de que Olímpia era uma boneca, mas por ter sido colocado na posição de objeto do desejo do mecânico no momento em que este o atinge com os olhos da boneca. Esta violência colocou o personagem em contato com uma angústia derivada do encontro não com os olhos, mas com o olhar enquanto objeto.

A boneca Olímpia aparece, nesta cena, como o duplo de Nataniel. O duplo é outra forma pela qual Freud (1919b/1980) aborda o estranho. A principal característica do duplo, segundo ele, é o trânsito de pensamentos e sentimentos entre uma pessoa e outra, o que introduz a dúvida sobre o que pertence ao próprio eu e o que vem do eu estranho. Quinet (2009), ao comentar este fenômeno, indica que o duplo não se refere à imagem narcísica, mas ao objeto olhar, e por isso ele afirma que a análise do fenômeno do estranho deve ter como principal referência o objeto $a$, "o outro radical ao sujeito" (p.10), para além do eixo especular.

Para compreender isto é necessário ter em mente que o olho mantém uma relação importante com o espaço. Não é possível considerá-lo sem ao mesmo tempo estabelecer a localização do corpo que, nesta relação com o espaço, parece constituir uma unidade: "através da forma i(a), a minha imagem, minha presença 
no Outro, não tem resto. Não consigo ver o que perco ali. É esse o sentido do estádio do espelho" (Lacan, 2005, p.277). O $a$ será associado a este resto que não aparece na imagem, mas cuja incidência é captada sob a forma de algo que altera a imagem, como uma mancha na cena. Esta mancha, diz Lacan (2005), é o que faz do $a$ um "sinal que me olha" (p.277). É o que fica exemplificado no olho branco do cego: não me encontro imediatamente na relação com o outro porque não sou capaz de saber como sou visto. Nesta situação desaparece a reflexividade da relação especular, restando apenas o $a$ como objeto olhar, cuja intervenção é fonte de inquietante estranheza. 


\title{
4.3. \\ Para além do imaginário
}

A temática do estranho permite introduzir a consideração sobre o que acontece quando a estabilidade obtida na relação imaginária é ameaçada. $\mathrm{O}$ tom de horror presente no relato de Hoffman já dá uma ideia de que a experiência do duplo contém uma face desestabilizadora, que foi capaz de levar o personagem a destruir a própria vida para livrar-se do estado de desespero em que se encontrava. Ao tratar o estranho como referência indispensável ao estudo da angústia, Lacan (2005) não estabelece uma equivalência entre os dois fenômenos, como pode parecer à primeira vista, mas se esforça para mostrar que possuem diferenças estruturais:

\begin{abstract}
Mesmo na experiência do espelho, pode surgir um momento em que a imagem que acreditamos estar contida nele se modifique. Quando essa imagem especular que temos diante de nós, que é nossa altura, nosso rosto, nosso par de olhos, deixa surgir a dimensão de nosso próprio olhar, o valor da imagem começa a se modificar - sobretudo quando há um momento em que o olhar que aparece no espelho começa a não mais olhar para nós mesmos. Initium, aura, aurora de um sentimento de estranheza que é a porta aberta para a angústia (p.100).
\end{abstract}

O que se apresenta tanto no conto de Hoffman quanto nos outros exemplos apresentados por Freud é algum elemento que não se ajusta ao universo imaginário do sujeito. Lacan (2005) volta ao esquema ótico para, a partir do estranho, avançar sobre o fenômeno da angústia. Desta vez ele faz uso de um esquema simplificado para desenvolver sua ideia a respeito da relação entre o investimento libidinal sobre a imagem e o lugar de aparecimento da angústia:

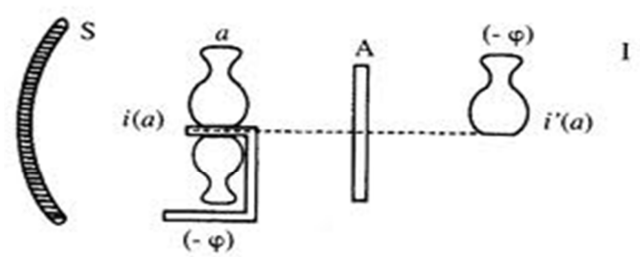

Esquema simplificado

O i(a) serve para indicar a imagem real do corpo, lugar onde se mantém uma reserva de libido. Trata-se, portanto, do corpo libidinizado. O i'(a) é a 
imagem virtual, sobre a qual paira o - , indicador do falo imaginário, aquilo que diz respeito a uma parte do corpo que pode ter imagem especular mas que ao mesmo tempo mantém uma certa relação com o campo da falta, pois não corresponde totalmente ao órgão. O objeto $a$, extraído do corpo, é percebido apenas como algo que falta na imagem, ou seja, não é possível abordá-lo diretamente: "O $a$, suporte do desejo na fantasia, não é visível naquilo que constitui para o homem a imagem de seu desejo" (Lacan, 2005, p.51). Para lidar com ele faz-se necessário, além do imaginário, o simbólico.Talvez por isso a letra A tenha sido colocada acima do espelho, mostrando que a produção da imagem é mediada pela autenticação do Outro, sem o qual o sujeito fica abandonado às suas pulsões, sem recursos para dar algum destino a elas. A rigor, o sujeito de desejo só poderá se constituir a partir do momento em que aparece na imagem algum indício da falta. A imagem, neste sentido, é sempre um engodo quanto àquilo que suscita o desejo. $\mathrm{O}$ que há de realmente atraente na imagem nunca se encontra nela e, por este motivo, quanto mais se tenta alcançar o que é considerado o objeto do desejo, torna-se mais consolidada a sua imagem e, por conseguinte, maior é o engajamento do sujeito naquele engodo.

O $a$ é aquele objeto que complica a tentativa de estabelecer alguma relação de objeto capaz de proporcionar uma imagem íntegra e estável, capaz de colocar o sujeito livre do acossamento de suas pulsões. Era isso que Hans tentava obter em sua pesquisa insistente acerca da diferença sexual. Ele pôde desfrutar de certa tranquilidade enquanto sua crença de que as mulheres tinham pênis permanecia intacta. Lacan (2005) está convencido de que se algo pode provocar angústia, é porque possui alguma afinidade com aquilo que não é assimilado na imagem. Ele considera que Freud está sempre se referindo a este objeto em todas as ocasiões em que fala de objeto da angústia. A relação com os objetos jamais poderá devolver o sujeito ao seu próprio corpo, pois haverá sempre algo perdido, de modo que nenhuma plenitude na imagem de si poderá ser obtida. É exatamente este furo irreparável no imaginário que a angústia demonstra de modo contundente:

A angústia surge quando um mecanismo faz aparecer alguma coisa no lugar que chamarei, para me fazer entender, de natural, ou seja, o lugar - , que corresponde, do lado direito, ao lugar ocupado, do lado esquerdo, pelo $a$ do objeto 
do desejo. Eu disse alguma coisa - entendam uma coisa qualquer. (Lacan, 2005, p.51).

A angústia está associada à castração imaginária. É daí que se deriva a tão repetida definição lacaniana da angústia: é quando a falta vem a faltar. A castração, por ser importante para a constituição da dialética do desejo, deve manter-se como parte da imagem apreendida no lugar do Outro, condição demarcada por i`(a). É nesta imagem que se apreende a relação do desejo com algo que está ausente. O que está ausente na imagem é precisamente aquilo que, mesmo estando muito perto do sujeito, não é apreensível.

Este - em torno do qual se desenrola o comentário lacaniano sobre a angústia é interpretado como o Heim, isto é, a casa. É o lugar onde habitamos no campo do Outro, sendo ao mesmo tempo familiar e oculto, conforme a definição do termo heimlich, descoberta por Freud (1919b/1980, p.282) em sua pesquisa sobre as raízes etimológicas do termo "estranho". Ao situar o estranho em seu esquema ótico, Lacan (2005) interpreta ao seu modo o fenômeno do duplo. Ele considera que "o homem encontra sua casa num ponto situado no Outro para além da imagem de que somos feitos" (p.58). A aproximação desta presença-ausente envolve a imagem especular, a transforma na imagem do duplo e, deste modo, abala a ilusão de nossa autonomia, pois torna explícito que há uma parte de nossa existência que não é apenas ignorada, mas também inassimilável ao campo das representações. É na experiência do duplo que se apreende a pertença do sujeito a um domínio que lhe escapa mas ao mesmo tempo o constitui:

Neste ponto Heim, não se manifesta simplesmente aquilo que vocês sempre souberam: que o desejo se revela como desejo do Outro [...] mas também que meu desejo, diria eu, entra na toca em que é esperado desde a eternidade, sob a forma do objeto que sou, na medida em que ele me exila de minha subjetividade, resolvendo por si todos os significantes a que ela está ligada (Lacan, 2005, p.58-59).

A teoria lacaniana parece enfatizar em diversos momentos a anterioridade do exterior em relação ao interior. Um exemplo disto pode ser encontrado na localização do $a$ que aparece do lado esquerdo do esquema simplificado, sobre o vaso. Ele já presente ali antes que o sujeito possa capturar sua imagem no lugar do Outro, a partir do qual conquista a distinção entre eu e não-eu. Lacan (2005) pondera que se Freud encontrou com uma "rocha" na 
condução de suas análises, pode-se dizer que ela é o objeto a, "a reserva derradeira e irredutível da libido" (p.121), radicalmente vinculada a uma parte do corpo desde o momento em que este não estava constituído como imagem. $\mathrm{O}$ esquema do espelho favoreceu a compreensão de que a presença do $a$ se insinua no campo do Outro como uma falta, em um ponto que ultrapassa até mesmo aquele onde o retorno do recalcado pode se manifestar:

[É] na medida em que esse lugar vazio é visado como tal que se institui a dimensão sempre negligenciada, por razões evidentes, quando se trata da transferência. Esse lugar, delimitado por algo que é materializado na imagem uma borda, uma abertura, uma hiância -, onde a constituição da imagem especular mostra seu limite, é o lugar de eleição da angústia (Lacan, 2005, p.121).

Esta borda que a imagem não pode eliminar é o que explica a experiência de iminente despersonalização que acompanha a angústia. Como só é possível ter a experiência de si mesmo a partir da constituição de uma imagem do corpo no campo do Outro, o que a angústia atesta é a existência de um limite na formação desta imagem. Diante desta borda presente no campo imaginário o sujeito se descobre na iminência de se precipitar como objeto no vazio aberto na organização do eu.

A temática do limite aparece no Seminário X, em determinado momento, articulada tanto à formação do eu quanto ao tratamento psicanalítico. A este respeito, Lacan (2005) observa que é no lugar no lugar do - $\theta v \varepsilon$ se instala a "angústia, a angústia de castração, em sua relação com o Outro" (p.55). Ele indica que se deve adotar esta referência na abordagem do problema que Freud encontrou na condução de suas análises, que sempre se detinham na angústia de castração. Lacan (2005) entende que não se pode atribuir a esta forma de castração o impasse nas análises de Freud, pois ela é parte da dinâmica libidinal do sujeito, tendo participação, inclusive, na constituição do eu. Para ele, o neurótico não evita a castração propriamente dita, mas sim a tarefa de assumir sua castração como aquilo que pode sustentar a relação com o Outro, este que sempre se furta na cadeia infinita de significações: "dedicar sua castração à garantia do Outro, é diante disso que o neurótico se detém. Ele se detém aí por uma razão como que interna à análise, e que decorre de que é a análise que o leva a esse encontro" (p.56). 
Esta passagem impõe a tarefa de esclarecer a relação entre a angústia e o Outro, bem como as possíveis consequências para a condução de uma análise. 


\section{5 \\ A angústia na direção do tratamento}

\section{1. \\ O objeto da angústia}

Em alguns momentos do seminário dedicado à angústia, é possível observar a preocupação de Lacan em mostrar aos seus ouvintes que a psicanálise opera sobre um sujeito cuja condição é muito particular, pois ele não corresponde ao sujeito clássico proposto pela teoria do conhecimento. A introdução do sujeito suposto saber em suas proposições acerca da transferência tinha como mote a crença na ilusão de um sujeito capaz de atingir um saber que seja seguramente verdadeiro. Uma das principais contribuições da psicanálise consistiu em mostrar que o sujeito cognoscitivo está fadado ao erro, na medida em que o ato de conhecimento está assentado numa relação com um objeto ilusório, cuja constituição está articulada fundamentalmente às coordenadas do estádio do espelho.

Isto significa que o conhecimento tem sua raiz na imagem do corpo próprio, cuja contemplação produz um júbilo tão intenso que é capaz de gerar a certeza de que o sujeito tem uma relação consigo mesmo que não dá margem ao equívoco. Entretanto, a imagem não dá conta de constituir uma experiência de integridade corporal que seja imune a perturbações. Isto impede que se possa ficar sempre seguro de si mesmo, porque o corpo não é uma totalidade estável. O espelho cria a ilusão de que a consciência de si é soberana, ou seja, que sabemos o que somos. Como o objeto de conhecimento é estabelecido sempre tendo por referência a imagem especular, a ilusão da certeza de si propicia o estabelecimento da certeza do conhecimento. A experiência do estranho, comentada anteriormente, é o que atesta o aparecimento de um objeto capaz de levar o sujeito à incerteza de si, questionando todas as suas relações com o domínio do conhecimento.

Vieira (2002) se aproxima desta abordagem ao considerar que a produção de um conceito de angústia ocorre na modernidade porque é no contexto da 
hegemonia do discurso científico que este afeto é percebido como uma manifestação estranha ao sentido que o conhecimento da ciência dá ao universo. Todo o esforço de Freud para determinar uma causa para a angústia é, segundo ele, efeito desta tendência moderna de estabelecer uma explicação para a realidade.

A angústia, contudo, é a presentificação do nada. Ao surgir, ela provoca o desmoronamento do campo do sentido. De acordo com Vieira (2002), o conceito de objeto $a$ foi criado por Lacan para dar conta da presença de um excesso que, ao mesmo tempo em que impõe um limite ao campo do sentido, é o que motiva o desejo, justamente porque introduz o sujeito numa região obscura de sua realidade, incitando-o a desvendá-la. A referência a este objeto introduz uma importante mudança na concepção da relação eu-outro no contexto da transferência. Ele considera que o par que interessa à clínica psicanalítica

não é o angustiado existencial e o analista típico, mas o angustiado e esse algo que desconstrói seu mundo a cada esquina, esse objeto que insiste em todos os objetos que ele deseja cotidianamente, mas não consiste em nenhum deles. O verdadeiro par em questão é o angustiado e seu objeto (Vieira, 2002, p.81).

A reversibilidade existente na libido, que transita sempre entre i(a) e i'(a) no esquema simplificado do espelho, esbarra com a intervenção de algo que não se acomoda na economia libidinal: o objeto $a$. Ao introduzir este conceito, Lacan vai ao centro da problemática da relação sujeito-objeto. O que se destaca em sua contribuição sobre este tema é a ideia de que a angústia assinala a presença de um objeto que não corresponde às concepções tradicionais da filosofia do conhecimento. Neste sentido, a angústia possui um valor epistêmico para a psicanálise, mas de um modo completamente novo, pois introduz um objeto “externo a qualquer definição possível da objetividade" (Lacan, 2005, p.99).

É compreensível, então, que o corpo tenha sido uma realidade sempre problemática desde o início da psicanálise, pois muito cedo Freud encarou em seus pacientes a presença de forças que não podiam ser estudadas dentro do modelo de corpo proposto pela ciência da época. O fato de que os sintomas histéricos não obedeciam às leis da neurociência vigente naquele tempo certamente foi um dos fatores que impulsionou o surgimento da psicanálise. A presença deste objeto sem objetividade na teoria lacaniana é um modo de abordar a ruptura introduzida na realidade pelo aparecimento do sujeito do inconsciente. 
Talvez por isso o matema da fantasia $(\exists \& \forall)$, que constitui a realidade sobre a qual o psicanalista intervém, seja composto precisamente pelo sujeito dividido e o objeto $a$. Na estrutura da fantasia encontra-se a íntima relação entre o sujeito do inconsciente e a deste objeto que não se presta à objetivação. Neste sentido, a experiência do estranho pode ser entendida como o momento em que se torna possível o aparecimento deste objeto, anulando temporariamente o reconhecimento de si e do mundo. Trata-se de uma possibilidade, pois o sujeito pode recuperar-se rapidamente da vacilação causada pela proximidade daquele objeto, evitando, assim, a angústia. Se isto não acontece, o estranhamento é acompanhado da angústia, até o momento em que o sujeito não sabe mais quem ele é. Se, por um lado, o estranho é percebido a partir de uma referência a algo familiar, que permite ter a percepção do que está fora do ordenamento da fantasia, a angústia tem o poder de fazer com que esta desmorone, incidindo como um corte que nos aproxima do objeto $a$ :

\begin{abstract}
A angústia é esse corte - esse corte nítido sem o qual a presença do significante, seu funcionamento, seu sulco no real, é impensável; é esse corte a se abrir, e deixando aparecer o que vocês entenderão melhor agora: o inesperado, a visita, a notícia, aquilo que é tão bem exprimido pelo termo "pressentimento", que não deve ser simplesmente entendido como o pressentimento de algo, mas também como o pré-sentimento, o que existe antes do nascimento de um sentimento (Lacan, 2005, p.88).
\end{abstract}

A relação entre a angústia e o corte faz com que seja quase inevitável o ressurgimento do caso do pequeno Hans, de maneira mais específica, a passagem em que o complexo da castração se expressa na fantasia de que o faz-pipi seja desatarraxado pelo instalador de torneiras. Este tratamento simbólico da possibilidade de que o pênis não exista - é isto que o órgão sexual feminino anuncia - permite ao sujeito evitar o confronto direto com o corte que separa homem e mulher, e que não pode ser eliminado. Ele teve que enfrentar a descoberta de que existe uma parte do seu corpo perdida, o que fica evidente na passagem do pênis como algo fixado ao corpo para a condição de um objeto que pode ser tomado por outro. Não ter recursos para fazer frente a este corte é o que favorece a experiência da angústia.

Ao converter o faz-pipi em objeto removível, Hans demonstra um aspecto do estádio do espelho referente ao uso do objeto como mediador da relação com o outro, permitindo superar a dificuldade em perceber a diferença em relação a ele, 
uma vez que neste momento prevalece a relação transicional entre o eu e o semelhante. É aí que o objeto surge como algo que pode ser disputado, instaurando, assim, a concorrência pela sua posse e ao mesmo tempo por uma afirmação de si diante do outro.

Para compreender a especificidade do objeto $a$, é imprescindível notar que ele se origina no campo do Outro como algo que escapa da incidência significante. Ao mesmo tempo em que o sujeito barrado é constituído como marca do significante, o a surge como algo que é separado do sujeito, mas que continuará presente na estruturação do desejo, desde que permaneça oculto na trama da fantasia. É isto que faz com que a angústia não engane, pois nenhum objeto é capaz de se ligar a ela, na medida em que é o $a$ que está implicado na sua produção, e este objeto não pode ser incluído na cadeia significante, que é onde o engano e a dúvida podem surgir. Deste $a$ não escapamos, e por isso a angústia é sempre algo cuja existência jamais é motivo de dúvida, embora o sujeito não consiga falar dela:

O objeto $a$ é postulado como o que antecede o sujeito. É o real do corpo anterior a qualquer delineação imaginária, anterior à ordenação simbólica. Com o advento do sujeito no lugar do Outro, esse objeto se torna vestígio, resto de algo que não pertence a um mundo constituído na lógica significante (Viola \& Vorcaro, 2011, p.92)

A experiência da angústia deriva sua certeza do fato, já observado por Freud em toda sua pesquisa sobre o tema, de que sua origem está no corpo, mas um corpo cuja imagem é articulada ao campo do Outro em um ponto inapreensível, sempre externo ao próprio sujeito, mas ao mesmo tempo muito íntimo. Não deve surpreender, então, que, ao falar da angústia, Lacan (2005) sugira que ela é um modo de comunicação absoluto entre o sujeito e o Outro, de tal modo que se pode afirmar que ela é "comum aos dois" (p.130). É sobre esta estrutura de comunicação absoluta que se introduz a relação entre angústia e desejo do Outro, e suas implicações para a relação entre analisando e analista. 


\section{2 \\ Angústia e desejo do Outro}

Freud postulou que a angústia é o sinal de um perigo e a teoria lacaniana incorporou esta ideia para aprimorá-la, introduzindo uma nova perspectiva sobre o significado deste "perigo". Se, por um lado, a angústia não deve ser estimulada na condução de uma análise, ela também não deve ser desprezada por seu poder de fazer com que o analisando se sinta ameaçado. Sem dúvida, a angústia pode levar ao abandono do tratamento ou a uma resistência difícil de superar, mas estes obstáculos podem ser evitados se o analista estiver ciente do que o analisando evita quando a angústia se instala.

A contribuição lacaniana sobre a angústia não abandonou o que Freud havia ensinado a respeito da distinção entre a angústia traumática, relacionada ao desamparo, e a angústia sinal. Permanece válida a ideia de que a angústia serve para indicar o retorno de um desejo recalcado, que em Lacan (2005) é descrito como desejo do Outro, que se apresenta como uma demanda

que não concerne a necessidade alguma, que não concerne a outra coisa senão meu próprio ser, isto é, que me questiona. Digamos que ele me anula. Em princípio, não se dirige a mim como presente, dirige-se a mim, se vocês quiserem, como esperado, e, muito mais ainda, como perdido. Ele solicita minha perda, para que o Outro se encontre aí. Isso é a angústia. (p.169).

Segundo Rudge (2005) este Outro do desejo que se manifesta ao sujeito é "vestígio do Outro primordial, específico, que me recebeu nesse mundo" (p.85). Isto significa, segundo a autora, que a posição primordial do sujeito quando vem ao mundo é o de causa do desejo do Outro, ao qual o seu próprio desejo irá se conformar. Esta é uma determinação estrutural que fará com que a partir deste momento o desejo do sujeito seja, fundamentalmente, causar o desejo do Outro. Contudo, esta busca não é tranquila, porque o sujeito experimenta a angústia ao se deparar com o caráter indeterminado do desejo do Outro. É isto que Lacan (2005) tenta transmitir com o seu famoso apólogo do louva-a-deus. Em resumo, o apólogo consiste na aparição de um gigantesco louva-a-deus fêmea diante do próprio Lacan, que estaria usando uma máscara cuja aparência ele mesmo desconhece, e que não consegue ver refletida no olho do inseto. Caso sua máscara seja a de um louva-a-deus macho, é possível que a fêmea, muito maior, esteja 
prestes a devorá-lo. O Outro cujas intenções não podem ser apreendidas suscita uma questão fundamental: "Que quer ele a respeito deste lugar do eu?" (p.14). Ele afirma, em seguida, que é nesta relação entre a identificação narcísica e a emergência do desejo que "veremos introduzir-se a função da angústia" (p.15). É a partir do questionamento sobre o que ele quer de mim que se articula o desejo do Outro à angústia

De acordo com Rabinovich (2000), a angústia primordial corresponde ao momento em que o sujeito cai como objeto diante do Outro. É a partir desta queda que se instala a causa do desejo. Se o sujeito não se torna perdido como objeto, também fica inviável para ele causar o desejo do Outro. Este desejo se sustenta na falta que o sujeito introduz no campo do Outro no momento em que se constitui. O sujeito enquanto causa está identificado à sua própria queda como resto do campo do Outro. A autora mostra que a relação entre o sujeito e o Outro tem uma importante consequência clínica:

O analista, colocado no lugar da causa de desejo, está ali para captar o próprio sujeito como objeto. Não capta um objeto de desejo do sujeito, um objeto meta do desejo, mas o sujeito como desejante do desejo do Outro, a partir da posição de causa desse desejo do Outro (Rabinovich, 2000, p.84)

É como se angústia tivesse duas faces: uma voltada para o desejo do Outro e outra voltada para a queda do sujeito como objeto. É importante notar que o efeito de questionamento oriundo do desejo do Outro não coloca o sujeito como objeto no plano imaginário, o que resultaria numa relação suscetível à disputa e à violência. O Outro simplesmente interpela o sujeito como causa de desejo, $a$. Este movimento é sempre anterior ao advento do sujeito, e por isso Lacan (2005) afirma que não há outra saída senão o engajamento nesta condição. Ele afirma que esta dimensão temporal, caracterizada pela anterioridade da condição de objeto, "é a angústia, essa dimensão temporal é a da análise" (Lacan, 2005, p.170).

Eis uma surpreendente aproximação entre angústia e análise, que só fica mais clara quando se considera que no tratamento o encontro com o desejo daquele que ocupa o lugar de analista atualiza esta dinâmica interpeladora trazida pela dimensão do Outro. Isto significa que o desejo do analista tem como principal efeito suscitar uma expectativa que funciona como propulsora da análise, o que provoca uma resposta que tenta suplantar o vazio instalado no lugar ocupado pelo analista: "Eu gostaria muito que ele me visse como isto ou aquilo, 
que fizesse de mim um objeto" (Lacan, 2005, p.170). O analisando se esforça para colocar algo no lugar em que aparece apenas um $x$, digamos assim, um signo do enigma que o desejo do analista comporta. É isto que configura o registro da demanda de amor, pela qual o sujeito se dirige ao Outro - encarnado pelo analista na transferência - como o lugar de onde pode vir uma resposta capaz de livrá-lo do desamparo.

A demanda repete a atitude da criança ao buscar na mãe a satisfação da necessidade. Segundo Elia (2004), por ser incapaz de realizar a ação capaz de assegurar sua satisfação, a criança fica na dependência do próximo para conseguir atender suas necessidades. Ele considera que a ação da mãe não consiste apenas na apresentação de um alimento, mas também do significante, o que abre para a criança dois planos: o plano do objeto necessário à sobrevivência e um outro plano que diz respeito à existência de alguém que traz o objeto. A passagem do objeto da necessidade para o objeto do desejo ocorre a partir da experiência da satisfação da necessidade, pela qual o sujeito é introduzido no campo da perda daquilo que lhe trouxe a satisfação. O desejo emerge como resposta a esta perda, ou seja, ele é a busca pelo retorno à experiência de satisfação inicial, enquanto a demanda é articulada no espaço aberto por esta passagem da necessidade ao desejo. É no plano da demanda que deve ser situado aquele alguém a quem a criança recorre, ou seja, o Outro. A introdução da linguagem na ordem da necessidade faz com que a criança deixe de se reportar ao seu cuidador apenas para receber o objeto da necessidade; ela também clama por sua presença, ou seja, seu amor.

De acordo com Torres (2011), a primeira relação com o próximo inaugura um movimento que consiste em reencontrar nos objetos empíricos o objeto da primeira satisfação. A partir do encontro com o Outro surgem, segundo ele, dois tempos: o primeiro seria o instante em que o sujeito se constitui na relação com o próximo (Nebenmensch), a partir da qual se constituem os circuitos que inauguram os processos de funcionamento do aparelho psíquico. A segunda modalidade de tempo seria o da repetição, que consiste em retornar aos circuitos produzidos pela experiência de satisfação. É neste segundo tempo que ele situa a noção lacaniana de que o desejo se estrutura na relação com o campo do Outro, ressaltando que o funcionamento do desejo supõe o primeiro tempo, pois é neste que se estabelece a cadeia significante, responsável pela articulação entre sujeito, 
objeto e desejo. Este objeto, no entanto, não é mais o objeto da necessidade, mas um objeto desconhecido pelo sujeito, embora esteja intimamente ligado à organização do seu desejo:

No quarto ano de seminário, eu quis mostrar-lhes que não existe objeto a não ser metonímico, sendo o objeto do desejo objeto do desejo do outro, e sendo o desejo sempre um desejo de Outra coisa - muito precisamente, daquilo que falta, $a$, o objeto perdido primordialmente (Lacan, 1999, p.16).

O sujeito dirige sua demanda ao Outro atraído por este objeto, sempre oculto em todos os objetos desejados. Ele é o "objeto causa do desejo, aquele que, por incidir como faltoso na experiência, causa o desejo do sujeito" (Elia, 2004, p.54-55). Não é possível haver demanda sem que esta já esteja vinculada ao desejo, que incide sobre ela, introduzindo a dimensão da impossibilidade de satisfação em que se apoia a insistência da demanda. É por esta razão que a demanda de um objeto sempre é sucedida por outro, indefinidamente, pois o objeto perdido nunca é reencontrado.

Lacan (1995) entende que a experiência da análise seria inconcebível se houvesse a possibilidade de uma relação harmônica entre sujeito e objeto. A ideia de que não existe objeto que leve o sujeito à completude é um aspecto essencial da noção de objeto em psicanálise. $\mathrm{Na}$ experiência analítica o objeto deve ser levado em conta, segundo ele, como algo que se coloca contra um "fundo de angústia", funcionando como instrumento para "mascarar, enfeitar o fundo fundamental de angústia que caracteriza, nas diferentes etapas do desenvolvimento do sujeito, sua relação com o mundo" (Lacan, 1995, p.21). Esta declaração situa-se no desenvolvimento da crítica lacaniana a qualquer pretensão de pautar a experiência de análise numa retificação das relações do sujeito com seus objetos, o que delimitaria o dispositivo analítico na relação dual que caracteriza o campo do imaginário.

Parece útil, neste momento, a distinção feita por Rabinovich (2005), em seu comentário sobre o Seminário X, entre o duplo imaginário e o duplo real. O ponto de partida do seu comentário é a ideia de que o surgimento do estranho ocorre quando a fantasia deixa de funcionar como um jogo do qual o sujeito toma parte, dando lugar ao aparecimento de uma parte de si mesmo que até então permanecia oculta. Neste instante o sujeito descobre que não tem o domínio total sobre a cena 
em que sua vida se desenvolve. Este elemento, apesar de oculto, é, surpreendentemente, aquilo em torno do qual tudo se organiza:

$\mathrm{Na}$ neurose, esse lugar, próprio dessa presença invisível, costuma instalar-se na demanda do Outro, constituindo o lugar do familiar, do heim. No heim, familiar, podemos situar a demanda. Quando a demanda do Outro é subvertida pela aparição que permite que essa presença invisível adquira a forma de presença, o que permite ali a passagem ao unheimlich? A aparição do desejo do Outro no lugar da demanda do Outro (Rabinovich, 2005, p.91).

É então que o sujeito é introduzido na experiência do duplo, pois repentinamente se converte em objeto posto diante do enigmático desejo do Outro. É o que ocorre, por exemplo, quanto se descobre, no ato de olhar, que também sou olhado. Enquanto o duplo especular é caracterizado pela rivalidade com o outro em torno de um objeto de desejo, no duplo real o sujeito não se encontra mais na relação com o outro especular, pois ele mesmo se converte em objeto. O que prevalece, portanto, é o seu corpo como objeto causa para o Outro, tal como ocorre com o personagem do conto $O$ homem de areia: o herói reage enlouquecendo no momento em que, do alto da torre, avista Coppelius, e tenta atirar sua noiva como vítima destinada a frear o avanço do Outro.

No conto de Hoffman fica evidente que a fantasia deixa de funcionar ao modo da pintura colocada sobre uma janela com o intuito de bloquear o que está além dela, conforme a descrição de Lacan (2005). Na cena final só há a janela da torre, sem uma tela que bloqueie a aproximação de Coppelius.

A fantasia, que normalmente funciona ocultando o desejo do Outro, isto é, sua falta, é ao mesmo tempo o que permite descobri-lo, e por isso é preciso atravessá-la para ter acesso ao desejo do Outro. Uma parte considerável do trabalho de análise consiste em recolher partes do discurso do analisando que se juntam para compor as cenas da fantasia. É por trás da janela da fantasia que se encontra o lugar escavado no Outro, onde o sujeito comparece como causa. O marco produzido no Outro se instala entre S1 e S2; este marco, "qualquer que seja a cena que se esboce no anteparo que o obtura, que o prende, é o próprio lugar da hiância constitutiva do desejo do Outro" (Rabinocivh, 2005, p.108). O sujeito está intimamente vinculado à hiância do desejo do Outro, e por isso se torna mais difícil manter nítida a distinção entre o que é interior e exterior ao sujeito quando 
se aborda a relação entre angústia e desejo. É esta estrutura ambígua que torna tão importante a noção de que o analista ocupa o lugar de causa do desejo:

Ao longo de uma análise, o analista alojará, nesse campo do Outro onde a estrutura o situa, essa forma da falta que é o $a$, até que, em sua queda, fique descoberta a hiância no Outro que a miragem do sujeito suposto saber encobria (Rabinovich, 2005, p.109)

Numa das primeiras lições de seu seminário, Lacan (2005) faz uma observação concernente à relação do analista com a angústia. Naquele contexto ele já tinha em mente que o desejo do Outro é o desejo que corresponde ao analista "como aquele que intervém como termo na experiência" (p.68). Na sequência declara que não pretende dissociar o analista da experiência que está sob investigação, pois a angústia "da qual temos que dar uma formulação aqui é uma angústia que responde a nós, uma angústia que provocamos" (p.68) em virtude da manifestação do desejo do Outro no lugar ocupado pelo analista. Assim, conclui Rabinovich (2005) "não é descabido pensar que o analista funciona como duplo real do sujeito, esse que a ficção fantástica descobre" (p.109) no fenômeno do estranho. 


\section{3 \\ A angústia de castração e o limite da análise}

A angústia é uma experiência que explicita a relação entre o corte e a dialética do desejo. Neste sentido, ela atesta a existência de um espaço estruturante entre o sujeito e o objeto da satisfação, o que torna a realização de um desejo algo que coloca o sujeito sempre diante da discrepância entre a satisfação almejada e aquela conquistada; é sempre a falta da satisfação desejada que ele encontra a cada vez que realiza algum desejo. De acordo com Vieira (2001), o objeto $a$ está situado na dialética do desejo como sendo o suposto objeto de satisfação total, ou seja, aquilo que se persegue em todos os objetos desejados. O $a$ é aquilo que está sempre além do lugar onde o desejo encontra sua satisfação, e por isso ele exerce o poder de continuar causando o desejo. A angústia, ele afirma, está relacionada "ao objeto como objeto impossível" (p.138). Ela se encontra entre a satisfação perdida (gozo) e a tentativa de recuperá-lo (desejo).

O exemplo dado no Seminário X para discutir a relação entre estes termos é o par mãe-bebê. Vieira (2001) esclarece que o que torna o seio algo desejável para a criança é o fato de que ele se reveste do brilho fálico, ou seja, é uma parte do corpo que surge para o bebê como promessa de conquista do gozo perdido, a qual é acessada pela criança no ato de sugar o leite. A criança se dirige ao seio graças ao valor que ele adquire nos momentos em que a mãe o alimenta, mas, para além da imagem do seio, está o $a$ : "Deseja-se, nos objetos, o falo, mas a causa do desejo é $a$ " (Vieira, 2001, p.139). A angústia é o efeito da presença do $a$ como aquilo que não se ajusta à hierarquização dos objetos de desejo promovida pelo falo. Ela aparece, no caso do par mãe-bebê em questão, por trás do seio, fora do campo de visão da criança, em um espaço que ela não é capaz de determinar. Ao afirmar que o corte está localizado entre a mãe e sua mama, Lacan (2005) consegue definir com precisão que o ponto de angústia está localizado além do campo formado pela junção entre a mama e a criança: "O ponto de angústia está no nível da mãe. [...] O lugar do ponto de angústia não se confunde com o lugar em que se estabelece a relação com o objeto do desejo" (Vieira, 2001, p.257).

O autor admite a existência de uma afinidade entre a função do corte e a castração. Contudo, o complexo de castração introduz uma realidade inversa, pois 
o ponto de angústia, neste caso, corresponde ao orgasmo, situado do lado do sujeito. Não há novidade nesta observação, pois desde as primeiras formulações freudianas sobre a angústia era possível identificar a ênfase dada à atividade copulatória na descrição deste afeto. Lacan (2005) considera que o funcionamento copulatório tem uma íntima relação com a castração, que, para ele, é um outro modo de se referir ao corte. Este, no caso da castração, manifesta-se na detumescência do pênis que acompanha o gozo sexual, uma imagem que é suficiente "para marcar a ligação do orgasmo com o que realmente se apresenta como imagem primeira, o esboço do corte - separação, amolecimento, afânise, desaparecimento da função do órgão" (p.261) .

É no desejo, e não na angústia, que Lacan (2005) centraliza seu comentário sobre a dificuldade encontrada por Freud na condução de suas análises. A questão da reivindicação do falo como impasse intransponível no final das análises freudianas, segundo ele, seria consequência da falta de uma distinção clara entre a relação do desejo com o objeto e o que caracteriza a dimensão da falta de satisfação, tão evidente na presentificação do corte no caso da afânise do órgão durante o orgasmo. Isto significa, tão somente, que o desejo está direcionado a um resto produzido na relação com o Outro que jamais será recuperado, razão pela qual o desejo comporta sempre algo de ilusório. O que o exemplo do orgasmo ilustra é o fato de que, na busca do objeto, o sujeito só encontra o - , e é isto que se converte para ele na forma essencial da satisfação almejada. Na verdade é o $a$, que não pode aparecer no espelho, que permite ao falo funcionar como o alvo do desejo. O $a$ é o resto de gozo que sempre fica de fora na imagem que se faz do objeto do desejo.

$\mathrm{O} a$ e o - são duas formas de falta articuladas à imagem especular. Também é possível descrever o falo como instrumento necessário à incidência do desejo na relação sexual, enquanto o objeto $a$ funciona como a causa do desejo: "Existe, portanto, uma hiância, um intervalo entre causa e instrumento" (Rabinovich, 2005, p.71). Tanto um quanto o outro tem relação com a angústia e

$4 \mathrm{O}$ fato de que o ponto de angústia no complexo de castração esteja relacionado deste modo à atividade copulatória é o que permite compreender a frequência com que certas situações de angústia são eliminadas com a produção de um orgasmo. $\mathrm{O}$ aparecimento destes casos na clínica parecem indicar o recurso à castração como operação de corte que propicia a fuga da situação angustiante, permitindo ao sujeito a recuperação de sua posição no campo do desejo. 
também com a constituição da imagem no estádio do espelho, no qual o sujeito conquista aquele estado que o permite afirmar "eu sou eu".

É importante lembrar que o falo como instrumento não é especularizável justamente porque é uma reserva libidinal que permanece ligada ao gozo autista, momento em que o Outro - componente indispensável do estádio do espelho está excluído. Se no estágio inicial da formação do eu existe o autoerotismo, a incidência da falta na constituição da imagem só pode ter surgido a partir de uma intervenção sobre a satisfação auto-erótica: "essa falta que é o $a$ ou o (- ) reside no Outro, não está meramente no lugar do Outro, mas na própria estrutura do Outro" (Rabinovich, 2005, p.79). É no campo do Outro que a dimensão da falta se instala. É por este motivo, segundo a autora, que a leitura do texto freudiano $O$ estranho suscita em Lacan a concepção da castração como correlata do aparecimento do Outro como desejante, isto é, como castrado. Nesta perspectiva, o penisneid e o temor da castração são interpretados como cenas traumáticas produtoras de uma fratura no imaginário, que é exatamente onde o estranho comparece:

a ruptura da unidade imaginária do corpo é provocada, realmente, pela insuficiência que encontra no nível das identificações imaginárias com os emblemas ideais, sexuados, representáveis no espaço da visão. A imagem especular sofre o trauma da irrupção da descoberta da não complementaridade do gozo sexual. Podemos pensar isso com o caso do pequeno Hans: como a primeira masturbação infantil provoca uma efração, uma ruptura da unidade da imagem especular, cuja consequência é uma fragmentação da unidade corporal imaginária (Rabinovich, 2005, p.82-83).

É o surgimento do Outro, portador de um desejo enigmático, que abala as identificações imaginárias. Até então, o falo desempenhava a função, como nos lembra Vieira (2001), de sustentar a crença no "verdadeiro eu", que é outra forma de entender o que é a unidade imaginária do corpo. Em sua relação com o desejo, o falo preserva a ilusão da existência do objeto do desejo, e por isso ele é aquilo que o orienta. Um outro modo de descrever o falo consiste em associá-lo à crença em um sentido primeiro que pode desvendar quem sou eu. Isto esclarece de maneira muito simples, por exemplo, o estranhamento experimentado quando surge algo que não se encaixa na organização do mundo promovida pelo falo. A partir deste fato torna-se mais compreensível porque a temática do estranho tenha interessado à Lacan no desenvolvimento de seu estudo sobre a angústia. O 
estranho é sempre algo que não se pode explicar ou compreender:

É justamente o desejo do Outro, direcionado para alguma coisa além da imagem do meu eu, coisa que nem eu mesmo consigo situar, o que causa a angústia. $\mathrm{O}$ desejo aparece, assim, na angústia, ligado ao real, limite da significação, ou seja, do campo fálico (Vieira, 2001, p.168).

É a permanência da crença na função do falo como aquilo que completa o eu que complica a conclusão das análises conduzidas por Freud, pois o homem, ao fim do tratamento recusa a posição passiva diante do analista, enquanto a mulher permanece invejando o pênis. $\mathrm{O}$ fundador da psicanálise, em um dos últimos textos de sua obra, escrito no fim da vida, admite que foram vãos todos os esforços para convencer uma mulher de que o desejo de um pênis é "irrealizável" ou demonstrar a um homem que nem sempre passividade diante de outro homem é sinônimo de castração (Freud, 1937/1980, p.286).

A partir da leitura lacaniana é possível afirmar que Freud estava lidando com a dificuldade de seus pacientes em lidar com seus desejos, que não encontram no outro a sua plenitude. Há sempre uma falta que o outro não pode suprir. Este desencontro colocado pela castração constitui a dinâmica da relação analítica. É no limite da análise freudiana que a angústia se revela como a "verdade da sexualidade" (Lacan, 2005, p.293), pois é este afeto que confronta o sujeito com o caráter ilusório do falo. Não sendo o órgão ou objeto - o falo é uma falta - ele não pode ser arrancado e nem restituído, como os pacientes de Freud esperavam: "O falo, ali onde é esperado como sexual, nunca aparece senão como falta, e é essa a sua ligação com a angústia” (Lacan, 2005, p.293). É o fato de não coincidir com o órgão que esclarece como a angústia revela a verdade da sexualidade, isto é, que homem e mulher só podem se relacionar pela mediação da falta: "É por não realizar o encontro dos desejos, a não ser em seu desvanecimento, que o falo se torna o lugar comum da angústia” (p.290).

O falo, como foi visto no capítulo sobre o estádio do espelho, desde o início da constituição do eu está articulado a um vazio que é estruturante da imagem. No entanto, com o recurso da fantasia, o neurótico tenta camuflar esta falta, sustentando-se na ficção de um eu pleno e forte, convertendo o falo em instrumento de potência. Se a angústia surge no momento em que se instala o impasse da castração é porque o sujeito se encontra com aquilo que torna o falo negativado na imagem, ou seja, o $a$, este lugar de gozo abrigado naquela região da 
imagem onde há um vazio. Lacan (2005) se expressa a respeito disto dizendo que este é "o momento caracterizado pela notação (- ), e que é a angústia de castração" (p.283). Ela expressa um limite inscrito na própria vida, que diz respeito a um gozo que extrapola os contornos estabelecidos pela imagem do eu.

O $a$ é o objeto que condensa este gozo perdido que o desejo tenta recuperar, e por isso ele surge como um limite para a significação, pois é o resto que escapa à função simbólica. É ele que, de certo modo, se articula ao limite da análise, pois tanto o homem quanto a mulher recusam a existência deste resto que não se deixa apreender pela significação fálica, e que impede a complementaridade sexual.

Segundo Quinet (2009), o tratamento psicanalítico conduz o sujeito à experiência de si mesmo como falta, e é esta experiência que configura a castração enquanto limite de um tratamento que tenha como meta a decifração do inconsciente e a concepção do sujeito como efeito do significante. Para que uma análise tenha um término possível, segundo o autor, ela deve estar orientada a um ponto fora do significante, ou seja, o $a$, cuja presença é indicada pela angústia. $\mathrm{O}$ surgimento deste afeto é o melhor indicador, para o analista, de que o sujeito se deparou com algo que, embora estranho, é parte de si mesmo. Descobrir-se como objeto do desejo do Outro significa que o sujeito enquanto efeito do significante desaparece momentaneamente, pois é o $a$ que se impõe. Este é o instante em que o tratamento pode chegar ao fim, pois é como objeto que posso "escapar do incessante remetimento das significações" (Rabinovich, 2005, p.88) que constitui o sujeito do inconsciente.

O ensino de Lacan (2005) indica que a angústia de castração só se torna um impasse quando o sujeito crê que o Outro realmente pode tirar-lhe algo. $\mathrm{Na}$ verdade o que pode ser eliminada é a castração, que é precisamente o que assegura a organização da imagem corporal acalentada pelo neurótico. Neste sentido, a angústia de castração demonstra o fracasso da ilusão do falo como plenitude do eu e aponta ao mesmo tempo para aquilo que é um resto, e que fica de fora da imagem do eu.

É preciso fazer algo deste resto, o $a$. É a partir dele que se torna possível desenhar um limite à tendência que a cadeia de significações possui de se encaminhar ao infinito. É claro que este limite não é absoluto, mas este resto que escapa ao simbólico, fonte de angústia, é o que, segundo Vieira (2008), permite afirmar simplesmente, num misto de resignação e esperança: "por hoje, chega" 
(p.105). Tal afirmação não é uma declaração de impotência, mas sim o reconhecimento de que a angústia pode ser um limite, mas para além dele se encontra o desejo enquanto desejo do Outro, fonte de uma inquietação que impulsiona o sujeito a seguir adiante, não obstante a impossibilidade de eliminar por completo a falta instalada pela perda do objeto.

A angústia pode ser um limite na constituição do sujeito e no tratamento, mas isto não significa que ela seja um obstáculo, necessariamente. O aparecimento deste afeto como algo relativo ao desejo do Outro tem outra implicação importante quanto à direção do tratamento, que não foi ignorada por Lacan (2005):

A existência da angústia está ligada a que toda demanda, mesmo a mais arcaica, tem sempre algo de enganoso em relação àquilo que preserva o lugar do desejo. Também é isso que explica a faceta angustiante daquilo que dá a essa falsa demanda uma resposta saturadora (p.76).

Esta passagem assinala que as modulações da demanda são produzidas em torno de uma falta - de comida, amor, atenção etc - cuja saturação é que provoca a angústia. A partir da demanda o sujeito espera uma resposta do Outro, e também, enquanto objeto de sua demanda, pode saber qual é a imagem que possui diante do Outro. Se demanda é anulada, o desejo fica isolado dela, e o sujeito perde a referência imaginária que o localizava no campo do Outro. É indispensável preservar o jogo da presença-ausência característico da articulação significante na qual a demanda se estrutura. É claro que ao evitar a saturação da demanda o analista não estará livre da angústia, pois ela pode aparecer em qualquer momento do tratamento e da vida do sujeito, ali onde o simbólico e o imaginário vacilam. Portanto, o analista jamais poderá se furtar à tarefa de dirigir o tratamento "bordejando" o limite indicado pela angústia, de modo que a análise seja "sempre angustiada o bastante para que haja mudança e jamais o bastante para que o silêncio se faça” (Vieira, 2001, p.165).

\section{Conclusão}


Ao concluir este trabalho, é possível perceber que o desenvolvimento do texto ocorreu pautado em um gradual deslocamento de ênfases. No primeiro momento, a ênfase era econômica. A gestão da excitação sexual estava na origem das manifestações da angústia. O recalque da sexualidade seria a causa da angústia, visto que produziria um acúmulo de libido a ser descarregada como angústia.

A partir dos desdobramentos teóricos suscitados pelas neuroses traumáticas a ênfase é transferida para o aspecto dinâmico, que corresponde à inauguração da segunda tópica, onde é consolidada a concepção da angústia como afeto relacionado às situações de perturbação da integridade do eu. A temática do perigo, após a fase "econômica" da teoria da angústia, torna-se dominante nos escritos freudianos, tais como o perigo da perda de objeto, perigo da castração ou perigo de vida. É importante ressaltar, entretanto, que a consideração sobre a perda, embora já estivesse presente no Projeto de 1895, só pôde ser vinculada à angústia quando ficou mais explícita a relação entre a sexualidade e a constituição do eu. Já não se trata mais, neste novo momento teórico, de considerar a angústia apenas como descarga de excitação sexual somática, mas também como efeito do apego à presença do Outro primordial como proteção contra o desamparo. Tal dinâmica tem como principal consequência a apreensão da libido como um perigo ao eu, na medida em que possa acarretar a perda do amor do adulto. Por esta razão, a angústia passa de efeito do recalque a ser considerada como causa do recalque.

Surge uma interessante correlação entre perigo interno e externo. Constata-se claramente a importância de considerar a relação entre o deslocamento da libido e a presença de um objeto muito particular: a mãe. A perda deste objeto, aparentemente externo, torna-se um perigo indissociável do aparecimento de uma modificação interna. Fica discernível a implicação entre a estabilidade narcísica e a perda deste objeto privilegiado, o que permite introduzir a importância, no surgimento da angústia, da separação da mãe.

Mas estas referências só puderam ser adequadamente apreciadas com a atenção dada ao papel do trauma na abordagem do perigo, pois foi a partir desta noção que ficou mais nítido o tênue limite entre o que é interno e externo ao psiquismo. A partir das pesquisas sobre o trauma, ganhou ainda mais força na 
teoria freudiana a vinculação entre angústia e a insuficiência de elaboração psíquica, que dá a este afeto o caráter de reação a um perigo difícil de discernir. A partir desta premissa, foi possível compreender a importância do debate sobre o trauma do nascimento para o desdobramentos sofridos na teorização sobre a angústia, a partir do qual este afeto é concebido como repetição da condição traumática representada pelo desamparo vivido pela criança ao nascer. A angústia , neste sentido, serve para alertar sobre o perigo de retornar a esta condição.

O desenvolvimento da criança, contudo, não é capaz de eliminar o malestar que o corpo produz. A angústia comemora sempre no corpo do sujeito o momento em que ele é introduzido no mundo. O trauma do nascimento, neste sentido, é radicalmente corporal, e por isso não equivale à simples separação do corpo da mãe, pois a criança neste momento não é capaz de simbolizar a experiência de separação, o que só é possível a partir da constituição do eu. Segundo Leite (2011), o nascimento é vivenciado como separação apenas pela mãe. Para a criança, o trauma do nascimento é comparável “à experiência de invasão, ou melhor, de aspiração de um ambiente absolutamente Outro em relação à criança" (p.52).

Lacan associa a angústia ao perigo de retornarmos ao colo, ou seja, a um estado em que a falta vem a faltar. De fato, a criança só fará a descoberta de que existe um espaço criado entre ela e a mãe a partir do estádio do espelho, quando ela começa a formar a imagem do corpo. É a partir deste período que a falta da falta significará uma ameaça de afânise do desejo e do espaço da subjetividade. A angústia, assim, aponta para esta experiência de ser aspirado no campo do Outro, dissolvendo-se a falta, ou seja, aquilo que permite à criança se constituir como sujeito diante do Outro.

O estudo do caso Hans possibilitou a convergência das considerações feitas nos dois primeiros capítulos, nos quais foram abordadas as relações da angústia com a sexualidade e a função de defesa desempenhada pela angústia. O comentário sobre a fobia de Hans foi desenvolvido a partir do surgimento da angústia de castração, cuja origem está relacionada à descoberta do pênis como sede de uma satisfação que a criança não consegue simbolizar. Este caso clínico ilustrou de que maneira o corpo se revela traumático ao destituir a criança do lugar que antes possuía na relação com sua mãe. Ao perceber que seu pênis é rejeitado por ela, Hans descobre que o desejo da mãe não está mais direcionado a 
ele, o que o deixa sem saber de que maneira poderá interessá-la: "A criança é então colocada diante dessa abertura de ser o cativo, a vítima, o elemento apassivado de um jogo onde vira presa das significações do Outro.” (Lacan, 1995, p.232). A angústia de castração, portanto, articula-se ao aparecimento de uma satisfação que não se acomoda à relação imaginária construída com a mãe. A fobia se instala para aplacar esta angústia, cuja incidência estava diretamente ligada à insistência do desejo de ficar próximo à ela.

A curiosidade de Hans sobre a posse do "pipi" atesta seu modo de lidar com a sexualidade. Sua crença na onipresença do falo é abalada pela descoberta gradual de que uma parte do seu próprio corpo não se encaixava mais em seu universo fálico. Ao perceber que seu pênis não interessa à mãe, Hans é confrontado com a castração dela, ou seja, com o fato de que lhe falta algo e que ele não pode oferecer aquilo que poderia suprir tal falta. Entra em jogo o nãosaber sobre a satisfação.

Ao recorrer à ordem simbólica, Hans pode “desatarraxar" seu "pipi”. Ao trocá-lo, ele introduz na dialética com o Outro sua castração, ou seja, ele transpõe o obstáculo colocado pelo falo imaginário a fim de introduzir o falo como significante da falta descoberta. Isto tudo ocorre porque a acomodação a uma imagem capaz de satisfazer o desejo da mãe foi perturbada pela agitação do pênis. Para enfrentar esta condição traumática e ao mesmo tempo preservar a relação com a mãe, o falo é instituído como elemento estruturante desta relação, permitindo velar o que há de traumático na mãe (sua castração) e ao mesmo tempo preservar a mãe como objeto do seu desejo. Parece que esta é a função desempenhada pela fantasia na qual sua mãe aparece "nua de camisola", o que é uma expressão do caráter ambíguo do falo, reabilitado para responder à insistência paterna de confrontá-lo diretamente com a realidade perturbadora do pênis. Hans põe em jogo a inexistência do falo como algo com que se deve jogar na forma de uma presença que se coloca na condição de algo velado. Hans tenta ver algo na mãe justamente porque não consegue ver completamente. Se a revelação é plena e direta, como o pai tenta fazer, a angústia surge.

De acordo com Vidal (1999), a fobia evidencia o encontro do sujeito com o objeto $a$. De fato, ele surge no ponto de angústia, onde se estabelece o corte entre a mãe e o filho. A imagem do corpo, que antes dava um contorno a este objeto condensador de gozo, encontra o seu limite. É neste ponto que o significante não 
consegue articular o gozo: "A imagem especular sofre o trauma da irrupção da descoberta da não-complementaridade do gozo sexual" (Rabinovich, 2005, p.83). No caso Hans, segundo a autora, é possível notar que a excitação do pênis surge como algo exterior ao corpo e ao mesmo tempo como algo dissociado do Outro. Tal descrição coincide com o lugar ocupado pelo objeto $a$ na estrutura, ou seja, localizado entre o sujeito e o Outro, mas não pertencendo a nenhum deles. $\mathrm{O}$ aparecimento deste gozo fora-do-corpo não pode ser inscrito no transitivismo da relação especular. Por isso a fobia surge como tentativa de deslocar este gozo para o campo do Outro, o que corresponde à entrada na dialética do desejo:

Aqui, a identificação imaginária, como mecanismo, encontra seu limite. No tocante ao gozo, a identificação só assume a figura da metáfora jurídica da posse, da propriedade, fundamento do que condena - no que diz respeito ao gozo - toda "propriedade" a ser a fonte de uma insatisfação estrutural [...] Insatisfação que desenha o lugar da perda do gozo-todo à qual a própria constituição do desejo obriga (Rabinovich, 2005, p.84).

Neste sentido, a angústia de castração corresponde a uma situação de desamparo gerada pelo encontro com a impossibilidade de comunicação entre o gozo do sujeito e o do Outro, ou seja, a inexistência da complementaridade sexual. Para sair da angústia gerada pela invasão de gozo é preciso renunciar a uma parte dele e ingressar na relação com o Outro pela via do desejo. O que fica evidente no caso Hans é que ele fica abandonado a uma satisfação com a qual não sabe lidar, pois não se acomoda à organização narcísica construída na relação com o outro (a mãe), que já havia sido perturbada pelo nascimento da irmã. Lacan mostra que é a falta da incidência castradora do pai que o deixa angustiado, ou seja, Hans fica refém do gozo que invade o seu corpo em virtude da aproximação materna. Então, é a falta da castração enquanto significante da perda que faz com que Hans não consiga barrar este gozo, ficando refém da indeterminação de que a presença materna se revestiu.

É possível perceber que o caso Hans reproduz o esquema da divisão subjetiva presente no Seminário X. A angústia aparece em Hans como uma zona limítrofe sobre a qual ele tenta se equilibrar para não desmoronar sob o gozo materno. Não se deve esquecer, entretanto, que no esquema está presente, de um lado, o gozo, e de outro, o desejo, sendo a angústia a mediana entre os dois. Tanto o nascimento de sua irmã quanto a agitação do seu pênis, rejeitado pela mãe, 
lançam-no, de fato, em uma queda da qual só pode se erguer se for capaz de restituir valor ao seu pênis, tarefa que se complica porque ele apreende este órgão como excluído da imagem corporal. A possibilidade de ser mordido, fantasia relativa à insatisfação da mãe, tira o pênis da condição de algo desprezível, recolocando-o novamente no circuito do desejo materno. Vale lembrar que a mordida aparece como algo ao mesmo tempo temido e desejado. A ameaça de perder o pênis é necessária para que algo do gozo seja cedido e ele possa aceder ao nível do desejo. A mordida do cavalo vem substituir a ausência da incidência castradora do pai. A mordida determina, enfim, o que é fundamental na angústia de castração, ou seja, uma angústia relativa ao fato de que o órgão real não passou ainda à função de simbolizar a falta do Outro, o que significa também lidar com a satisfação deste órgão como perdida, como algo que sempre escapa da organização corporal e que por isso participa da estrutura do desejo. É como se o sujeito se desse conta de que é preciso buscar alguma satisfação no Outro, pois ficar detido no auto-erotismo implica a própria destruição.

O estudo do estádio do espelho permitiu introduzir importantes referências sobre a perspectiva lacaniana acerca do corpo, assunto central no estudo da angústia. A tensão entre o que é interno e externo ao corpo - temática já esboçada nos textos freudianos - ganha uma nova abordagem a partir do emprego dos esquemas óticos. Juntamente com os comentários sobre a noção de "estranho", em Freud, foi possível estabelecer o lugar na estrutura do eu onde a angústia emerge, expondo a ambiguidade radical deste afeto, no qual o sujeito se descobre implicado numa parte de si mesmo que não consegue apreender. As considerações sobre o estranho, indissociáveis dos pressupostos sobre o estádio do espelho, tornaram possível a introdução da topologia do objeto $a$ na dissertação. O fato de que a forma do eu se apreende como algo externo na relação com o outro funcionou, no conjunto do trabalho, como antecipação da relação estrutural entre angústia e desejo do Outro, abordada nos capítulos finais.

O aspecto importante desta relação com o campo do Outro, e que se refere também ao caráter estranho do objeto $a$, no sentido em que ele não tem seus contornos delimitáveis na imagem do corpo, é a dimensão de equívoco que ele assume. O objeto $a$ não é, por exemplo, o seio enquanto órgão, mas esta região imprecisa entre o bebê e a mãe. É sempre no espaço entre que o objeto $a$ se insinua, o mesmo espaço relativo ao aparecimento do estranho. Se o sujeito se 
angustia diante da perda dos olhos, por exemplo, é porque ele está diante de um perigo radical: não tanto o de perder uma parte preciosa do corpo, mas o de perder a si mesmo para o desejo do Outro:

A angústia emerge nos momentos de separação, corte ou perda, momentos que comemoram a perda primeira. [...] A angústia aparece nos momentos em que o sujeito é obrigado a ceder - ceder algo precioso, algo que ele preferiria reter, algo cuja perda lhe ameaça de queda, desmoronamento, morte. [...] O dispositivo analítico, no que convoca o sujeito a falar, necessariamente o pressiona a dizer dizer que vai além de seus ditos, fala que o leva a ceder um a mais, algo a mais, um pequeno nada que, a qualquer custo, ele se aferra em reter e cuja perda é impossível deter (Souza, 2005, p.19).

Isto permite compreender que uma das maiores dificuldades na clínica consiste exatamente em levar o neurótico a assumir a perda como condição que lhe dá acesso ao seu desejo, que é sempre desejo do Outro. Uma das primeiras formas de contato do analisando com a dimensão da perda é o silêncio do analista, que, inicialmente, suscita o estabelecimento da demanda: "como vocês não lhe pedem nada, começa a modular as demandas dele, que vêm no lugar Heim. É essa a primeira entrada em análise" (Lacan, 2005, p.63). É neste lugar que o sujeito tenta habitar no tratamento, mas também é nele que o desejo do Outro se manifesta enquanto duplo do sujeito.

A angústia, sendo o que traduz subjetivamente o objeto $a$, é aquilo que coloca o sujeito na vizinhança do que o causa enquanto desejante a partir da interrogação que ele faz a si mesmo a respeito do que o Outro quer dele. Este objeto não está posicionado diante do desejo, não é o que o desejo visa. O objeto $a$ funciona como aquilo que causa o desejo, ou seja, ele está atrás do desejo. Esta inversão deve muito às contribuições de Freud sobre a topografia da pulsão. Para compreender a importância desta inovação, basta lembrar que o alvo da pulsão (Ziel) não se confunde com o objeto (Objekt). No plano da dinâmica pulsional há uma topologia cuja importância para a concepção lacaniana do objeto não pode ser negligenciada:

Há nesse nível uma oposição expressa entre dois termos - ausseres, externo, exterior, e inneres, interior. É indicado com precisão que o objeto deve ser situado ausseres, no exterior, e, por outro lado, que a satisfação da tendência só consegue realizar-se na medida em que se liga a alguma coisa que deve ser considerada no inneres, no interior do corpo, onde ela encontra sua Befriedigung, sua satisfação (Lacan, 2005, p.115). 
Ao colocar o objeto $a$ no centro do circuito pulsional Lacan conseguiu esclarecer como a angústia engaja tanto o corpo quanto o desejo do Outro. Sobre este assunto, Costa-Moura (2006) ressalta que a concepção de objeto $a$ diz respeito a uma espacialidade que não é representacional, ou seja, pertence a um campo onde não é possível estabelecer correspondência biunívoca entre representação e objeto. Em outras palavras, ele não é um objeto especularizável como aqueles com os quais lidamos usualmente. Por não ser duplicável numa imagem que o represente, este objeto só pode nos afetar em nosso corpo, naquilo que ele tem de estrangeiro à imagem. É o caráter subtrativo do objeto $a$ que o torna tão importante, pois ele faz com que o corpo se torne incompleto e também o Outro, tornando possível o movimento da cadeia significante e, por conseguinte, a constituição do sujeito. A angústia diz respeito a um momento anterior ao sujeito, instante em que ele está por vir, e por isso o objeto $a$ precisa continuar velado para que o desejo de recuperá-lo continue vivo. Se ele se insinua, a angústia surge, e o desejo desaparece.

A ideia de que a angústia surge no momento em que o objeto $a$ se apresenta não contradiz a compreensão freudiana da angústia como afeto provocado pela perda de objeto. As duas abordagens se revelam complementares quando se considera que o surgimento do objeto $a$ é indissociável do desaparecimento do objeto amado a partir do qual é constituída a imagem corporal (Leite, 2011, p.71).

A aproximação entre os temas da angústia e do amor parece muito promissora, pois não é raro observar na clínica o quanto a angústia está associada às situações de perda de uma relação afetiva. Além deste fato, o amor é a forma pela qual a transferência se instala como tentativa de negar a diferença sexual (Maurano, 2006). A angústia, por sua vez, revela que o falo não resolve igualmente para o homem e para a mulher a partilha dos sexos. O campo do feminino introduz um novo horizonte sobre a sexualidade, pois a mulher não conta com um referente corporal (pênis) que sirva de suporte para o significante fálico. A angústia parece ter uma íntima ligação com esta dimensão relativa ao "ilimitado, ao inacessível, em último caso, ao amor" que vem no lugar da "insuficiência da relação fálica [em] delinear tudo o que interessa à existência" (Maurano, 2006, p.51). 
A presença da angústia no tratamento parece demonstrar que nem mesmo o amor pode ocultar indefinidamente o objeto $a$, presente do lado do analista, mas camuflado pelos atributos que lhe são conferidos na investida amorosa. É a partir da angústia que se impõe a tarefa de ir além da castração, na via de um luto "de nosso atrelamento narcísico ao objeto fálico, com o qual tentamos sustentar a magnitude do Outro, como se isso nos garantisse alguma coisa" (Maurano, 2006, p.53). Para que isto ocorra, o analista deve intervir de modo que o analisando perceba que ele não tem o objeto que pode lhe restituir a integridade narcísica. Diante das insatisfações de suas demandas de amor, o sujeito é introduzido a algo que está para além da dimensão imaginária, pois a cada desencontro com o Outro do amor ele experimenta a persistência da pulsão. A insistência do traçado pulsional delimita cada vez mais aquilo que está no interior do objeto de amor: o $a$. Lacan (1964), no seminário posterior ao da angústia, deu uma importante indicação sobre a superação do plano da demanda no tratamento, destacando o lugar do objeto $a$ no manejo da transferência:

(...) se a transferência é aquilo que, da pulsão, desvia a demanda, o desejo do analista é aquilo que leva a demanda de volta a pulsão. E, pela via da pulsão, o desejo do analista isola o objeto $a$, situa-o à maior distância possível do I (ideal do eu) que o analista é chamado pelo sujeito a encarnar. É dessa idealização que o analista tem que tombar para ser o suporte do objeto $a$ separador (...) (Lacan, 1998, p. 258).

Se é possível afirmar que a angústia não é sem objeto, na medida em que ela está articulada ao objeto $a$, também parece válido concluir que uma análise não é sem angústia, pois este movimento de queda da idealização convoca o sujeito a assumir a falta que o constitui, atravessando a fantasia que construiu para responder ao desejo do Outro. Ultrapassar a fantasia é descobrir que o Outro não pode remediar o desamparo, e isto não acontece sem angústia. É possível entender, agora, porque Lacan (2005) afirma que a angústia tem a mesma estrutura da fantasia: ambas colocam em evidência a relação do sujeito com o objeto $a$. A fantasia não deixa este objeto aparecer, o que assegura o regime da falta como motor do desejo. Por outro lado, se este objeto aparece, a falta desaparece, o desejo cessa e o sujeito cai sob o peso da angústia. 
Entre angústia e desejo está a demanda de amor, ponte lançada sobre o abismo existente entre o sujeito e o Outro. Talvez a principal tarefa do analista na direção do tratamento consista em levar o analisando a descobrir a imensidão do vazio que está sob seus pés e, a partir desta descoberta, prosseguir advertidamente em seu desejo ou recuar diante da incerteza sobre o que poderá acontecer se continuar. 


\section{Referências}

CALAZANS, R. \& BASTOS, A. Passagem ao ato e acting out: duas respostas subjetivas. Fractal: Revista de Psicologia. Rio de Janeiro, vol.22, n.2, Mai/Ag.2010, pp. 245-256. Disponível em: http://www.scielo.br/pdf/fractal/v22n2/02.pdf . Acesso em 14 out. 2012.

CAMPOS, E.B.V. A primeira concepção freudiana da angústia: uma revisão crítica. Ágora, vol. 7, n. 1, Jan/Jun. 2004, pp. 87-107. Disponível em: http://www.scielo.br/pdf/agora/v7n1/v7n1a06.pdf Acesso em: 28/05/2013.

COSENTINO, J.C. A função da angústia. Letra Freudiana. Rio de Janeiro, Ano 14, n. 15. 1995, pp.101-119. Disponível em http://www.escolaletrafreudiana.com.br/publicacao/49/ . Acesso em $15 / 10 / 2012$.

COSTA-MOURA, F. A incidência real da causa na psicanálise. Revista do Departamento de Psicologia - UFF, v. 18, n. 1, Jan./Jun. 2006, pp. 117130.

CONTÉ, C. O real e o sexual: de Freud a Lacan. Rio de Janeiro: Jorge Zahar Editor, 1995.

ELIA, L. Corpo e sexualidade. $2^{\mathrm{a}}$. ed. Rio de Janeiro: UAPE, 1995.

O conceito de sujeito. Rio de Janeiro: Jorge Zahar Editor, 2004.

FREUD, S. (1894a) Como se origina a angústia (Rascunho E). Edição Standard das Obras Psicológicas Completas de Sigmund Freud, v. I. Rio de Janeiro: Imago, 1980.

- (1894b) As neuropsicoses de defesa. Edição Standard das Obras Psicológicas Completas de Sigmund Freud, v. III. Rio de Janeiro: Imago, 1980.

(1896) Novos comentários sobre as neuropsicoses de defesa. Edição Standard das Obras Psicológicas Completas de Sigmund Freud, v. III. Rio de Janeiro: Imago, 1980.

- (1895a) Sobre os critérios para destacar da neurastenia uma síndrome particular intitulada "neurose de angústia". Edição Standard das Obras Psicológicas Completas de Sigmund Freud, v. III Rio de Janeiro: Imago, 1980.

. (1895b) Obsessões e fobias. Edição Standard das Obras Psicológicas

Completas de Sigmund Freud, v. III Rio de Janeiro: Imago, 1980.

. (1895c) Uma réplica às críticas do meu artigo sobre neurose de angústia.

Edição Standard das Obras Psicológicas Completas de Sigmund Freud, v. III Rio de Janeiro: Imago, 1980.

. (1895d) Projeto para uma psicologia científica. Edição Standard das Obras Psicológicas Completas de Sigmund Freud, v. I Rio de Janeiro: Imago, 1980. 
(1897) Sinopses dos escritos científicos do Dr. Sigmund Freud. Edição Standard das Obras Psicológicas Completas de Sigmund Freud, v. III Rio de Janeiro: Imago, 1980.

. (1905) Três ensaios sobre a teoria da sexualidade. Edição Standard das Obras Psicológicas Completas de Sigmund Freud, v. VII Rio de Janeiro: Imago, 1980.

. (1909) Análise de uma fobia em um menino de cinco anos. Edição Standard das Obras Psicológicas Completas de Sigmund Freud, v.X. Rio de Janeiro: Imago, 1980.

(1914) Recordar, repetir e elaborar. Edição Standard das Obras Psicológicas Completas de Sigmund Freud, v.XII. Rio de Janeiro: Imago, 1980.

- (1917a) Os caminhos da formação dos sintomas (Conferência XXIII). Edição Standard das Obras Psicológicas Completas de Sigmund Freud, v.XVI. Rio de Janeiro: Imago, 1980.

. (1917b). A angústia (Conferência XXV). Edição Standard das Obras Psicológicas Completas de Sigmund Freud, v.XVI. Rio de Janeiro: Imago, 1980.

. (1919a) Introdução à A psicanálise e as neuroses de guerra . Edição Standard das Obras Psicológicas Completas de Sigmund Freud, v.XVII. Rio de Janeiro: Imago, 1980.

- (1919b) O estranho. Edição Standard das Obras Psicológicas Completas de Sigmund Freud, v.XVII. Rio de Janeiro: Imago, 1980.

. (1920) Além do princípio do prazer. Edição Standard das Obras Psicológicas Completas de Sigmund Freud, v.XVIII. Rio de Janeiro: Imago, 1980.

- (1923) A organização genital infantil: uma interpolação na teoria da sexualidade. Edição Standard das Obras Psicológicas Completas de Sigmund Freud, v.XIX. Rio de Janeiro: Imago, 1980.

. (1924) A dissolução do complexo de édipo. Edição Standard das Obras Psicológicas Completas de Sigmund Freud, v.XIX. Rio de Janeiro: Imago, 1980.

- (1926) Inibição, sintoma e angústia. Edição Standard das Obras Psicológicas Completas de Sigmund Freud, v.XX. Rio de Janeiro: Imago, 1980 .

(1933a). A dissecação da personalidade psíquica (Conferência XXXI). Edição Standard das Obras Psicológicas Completas de Sigmund Freud, v.XXII. Rio de Janeiro: Imago, 1980.

(1933b). Angústia e vida pulsional (Conferência XXXII). Edição Standard das Obras Psicológicas Completas de Sigmund Freud, v.XXII. Rio de Janeiro: Imago, 1980.

(1937). Análise terminável e interminável. Edição Standard das Obras Psicológicas Completas de Sigmund Freud, v.XXIII. Rio de Janeiro: Imago, 1980. 
(1939) Moisés e o Monoteísmo. Edição Standard das Obras Psicológicas Completas de Sigmund Freud, v.XXIII. Rio de Janeiro: Imago, 1980.

FUKS, B. Notas sobre o conceito de angústia. Estudos e pesquisa em psicologia. Rio de Janeiro, v.I, n.1, 2001. Disponível em http://www.revispsi.uerj.br/v1n1/sumariov1n1.html. Acesso em 17/10/2012.

KAUFFMAN, P. Libido. In: __ (Ed.) Dicionário Enciclopédico de Psicanálise: o legado de Freud e Lacan. Rio de Janeiro: Jorge Zahar Editor, 1996.

LACAN, J. (1948) A agressividade em psicanálise. In: Escritos. Rio de Janeiro: Jorge Zahar Editor, 1998. (1949) O estádio do espelho como formador da função do eu. In: Escritos. Rio de Janeiro: Jorge Zahar Editor, 1998.

O Seminário, livro 1: os escritos técnicos de Freud. Rio de Janeiro: Jorge Zahar Editor, 1986.

. O Seminário, livro 4: a relação de objeto. Rio de Janeiro: Jorge Zahar Editor, 1995.

. O Seminário, livro 5: as formações do inconsciente. Rio de Janeiro: Jorge Zahar Editor, 1999.

. O Seminário, livro 8: a transferência. Rio de Janeiro: Jorge Zahar Editor, 1992.

. O seminário, livro 10: a angústia. Rio de Janeiro: Jorge Zahar Editor, 2005 .

. O seminário, livro 11: os quaro conceitos fundamentais da psicanálise. Rio de Janeiro: Jorge Zahar Editor, 1998.

LAPLANCHE, J \& PONTALIS. Vocabulário de Psicanálise. $4^{\mathrm{a}}$ ed. São Paulo: Martins Fontes, 2001.

LEITE, S. Angústia. Rio de Janeiro: Jorge Zahar Ed., 2011.

MAURANO, D. A transferência. Rio de Janeiro: Jorge Zahar Ed., 2006.

QUINET, A. A estranheza da psicanálise: a Escola de Lacan e seus analistas. Rio de Janeiro: Jorge Zahar Ed., 2009.

RABINOVICH, D. O desejo do psicanalista: liberdade e determinação em psicanálise. Rio de Janeiro: Companhia de Freud, 2000.

. A angústia e o desejo do Outro. Rio de Janeiro: Companhia de Freud, 2005.

RUDGE, A. Pulsão e linguagem: esboço de uma concepção psicanalítica do ato. Rio de Janeiro: Jorge Zahar Editor, 1998.

. Trauma. Rio de Janeiro: Jorge Zahar Editor, 2009.

. Jones e Lacan: pesadelos, demônios e angústia. Pulsional, ano XVII, n.181, março. 2005, p.80-87. Disponível em: http://www.editoraescuta.com.br/pulsional/181_09.pdf Acesso em: $01 \mathrm{dez}$. 2013. 
SANTOS, T.C. Acting-out: o objeto causa de desejo na sessão analítica. OPÇÃO LACANIANA Revista Brasileira Internacional de Psicanálise, número 30, ed. Eólia, SP, 2001. Disponível em http://www.isepol.com/bibliotecavirtual/5acting_out.pdf. Acesso em 14/10/2012.

SOUZA, N.S. A angústia na experiência analítica. In: HANNA, M.S.G.F \& SOUZA, N.S. (Orgs.) O objeto da angústia. Rio de Janeiro: 7Letras, 2005.

TORRES, R. Indicações sobre a estrutura da ação específica freudiana: efeitos para o sujeito da psicanálise. Ágora. Rio de Janeiro, v.XIV, n.1, jan/jun 2011, pp. 61-76.

VANIER, A. Temos medo de quê? Ágora. Rio de Janeiro, v.XIX, n.2, jul/dez 2006, pp.285-298.

VIEIRA, M.A.V. A ética da paixão: uma teoria psicanalítica do afeto. Rio de Janeiro: Jorge Zahar Editor, 2001.

. Como se ri da angústia. In: BESSET, V.L.(Org.) Angústia. São Paulo: Escuta, 2002.

Restos. Rio de Janeiro: Contra Capa, 2008.

VIDAL, E. Hans e a Fobia. Letra Freudiana, n.24. Rio de Janeiro: Contra-Capa, 1999 ,

pp.209-

221.Disponívelem:http://www.escolaletrafreudiana.com.br/UserFiles/110/Fi le/artigos/letra24/027.pdf . Acesso em 25/09/2013.

VIOLA, D.T.D \& VORCARO, A.M.R. A verdade e o engodo do desejo na leitura do seminário A angústia de Jacques Lacan. Ágora. Rio de Janeiro, v. XIV n. 1 jan/jun 2011, pp. 77-93. 